\title{
Translating the Past: Local Romanesque Architecture in Germany and Its Fifteenth-Century Reinterpretation
}

\author{
Stephan Hoppe
}

The early history of northern Renaissance architecture has long been presented as being the inexorable occurrence of an almost viral dissemination of Italian Renaissance forms and motifs. ${ }^{1}$ For the last two decades, however, the interconnected and parallel histories of enfolding Renaissance humanism have produced new analytical models of reciprocal exchange and of an actively creative reception of knowledge, ideas, and texts yet to be adopted more widely by art historical research. ${ }^{2}$

In what follows, the focus will be on a particular part of the history of early German Renaissance architecture, i.e. on the new engagement with the historical - and by then long out-of-date - world of Romanesque architectural style and its possible connections to emerging Renaissance historiography

1 Cf. Hitchcock H.-R., German Renaissance Architecture (Princeton, NJ: 1981).

2 Burke P., The Renaissance (Atlantic Highlands, NJ: 1987); Black R., "Humanism", in Allmand C. (ed.), The New Cambridge Medieval History, c. 1415-c. 1500, vol. 7 (Cambridge: 1998) 243-277; Helmrath J., "Diffusion des Humanismus. Zur Einführung", in Helmrath J. - Muhlack U. Walther G. (eds.), Diffusion des Humanismus. Studien zur nationalen Geschichtsschreibung europäischer Humanisten (Göttingen: 2002) 9-34; Muhlack U., Renaissance und Humanismus (Berlin - Boston: 2017); Roeck B., Der Morgen der Welt. Die Geschichte der Renaissance (Munich: 2017). For more on the field of modern research in early German humanism, see note 98 below.

The following works may serve as examples of the current art historical debate that seek a more nuanced understanding of the exchange processes between the Renaissance arts outside Italy: Belozerskaya M., Rethinking the Renaissance: Burgundian Arts across Europe (Cambridge: 2002); Smith J.C., The Northern Renaissance (London: 2004); Nußbaum N. - Euskirchen C. - Hoppe S. (eds.), Wege zur Renaissance. Beobachtungen zu den Anfängen neuzeitlicher Kunstauffassung im Rheinland und in den Nachbargebieten um 1500 (Cologne: 2003); Chatenet M. - Kavaler E.M. (eds.), Le Gothique de la Renaissance, Actes des quatrièmes Rencontres d'architecture européenne, Paris, 12-16 juin 2007 (Paris: 2011); Hoppe S. - Nußbaum N. - Müller M. (eds.), Stil als Bedeutung in der nordalpinen Renaissance. Wiederentdeckung einer methodischen Nachbarschaft (Regensburg: 2008); Kavaler E.M., Renaissance Gothic: Architecture and the Arts in Northern Europe 1470-1540 (New Haven, CT: 2012).

(C) STEPHAN HOPPE, 2019 | DOI:10.1163/9789004378216_021

This is an open access chapter distributed under the terms of the prevailing CC-BY-NC-ND License at the time of publication. 
and thought. ${ }^{3} \mathrm{~A}$ rather new element in this context constitutes the analytical integration of the different roles taken on by learned and mobile Brückenfiguren (bridging figures), ${ }^{4}$ a number of German and Italian humanist writers, councillors, politicians, and courtiers, within transregional networks. Therefore, this essay attempts to sketch out the first outlines of an entangled history (histoire croisée) of early humanism and artistic developments in the late fifteenth century in Germany. In this way, the intellectual background between particular architectural innovations which can be labelled as a kind of Romanesque Renaissance may perhaps be better understood. In addition, some connections, little regarded thus far, between contemporaneous approaches to historiography and the search for an appropriate language of architecture can be opened up to an interdisciplinary debate.

Although the artistic and intellectual phenomena of the Romanesque Renaissance described in this essay do not end with the fifteenth century (and are not restricted to German-speaking lands), for reasons of space their continued existence and further development can only be traced into the early sixteenth century.

As the current state of art historical research indicates, the electoral Saxon court and its residences remodelled in the 1470 s played an important role in developing a new attitude towards the architectural achievements and stylistic idiosyncrasies of previous cultural eras.

3 My own scholarly engagement with the theme of a contemporary perception of different styles in the architecture of the early Renaissance (and late Gothic) outside Italy and of its context in the history of thought started in 2001 with my paper at the first Sigurd-GrevenColloquium at the University of Cologne on the beginnings of the Renaissance in the Rhineland (Hoppe, S., "Romanik als Antike und die baulichen Folgen. Mutmaßungen zu einem in Vergessenheit geratenen Diskurs", in Nußbaum - Euskirchen - Hoppe, Wege zur Renaissance 89-131). I would like to thank numerous colleagues who at the time received my perhaps somewhat unconventional theses with favour and who subsequently offered valuable suggestions and commentaries, in particular Hubertus Günther, Norbert Nußbaum, Claudia Eußkirchen, Krista De Jonge, Konrad Ottenheym (especially for coining the term 'Romanesque Renaissance' at a 2017 conference in Florence), Jean Guillaume, Hanns Hubach, Ute Verstegen, Matt Ethan Kavaler, and many more. I wish to thank Andrea M. Gáldy for her editorial assistance in preparing the present essay for its English-language publication. This essay is dedicated to Hubertus Günther and Jean Guillaume.

4 For this term of 'Brückenfigur', see Helmrath in relation to Enea Silvio Piccolomini: Helmrath J, 'Vestigia Aeneae imitari. Enea Silvio Piccolomini als 'Apostel' des Humanismus. Formen und Wege seiner Diffusion", in Helmrath - Muhlack - Walther, Diffusion des Humanismus 102. 


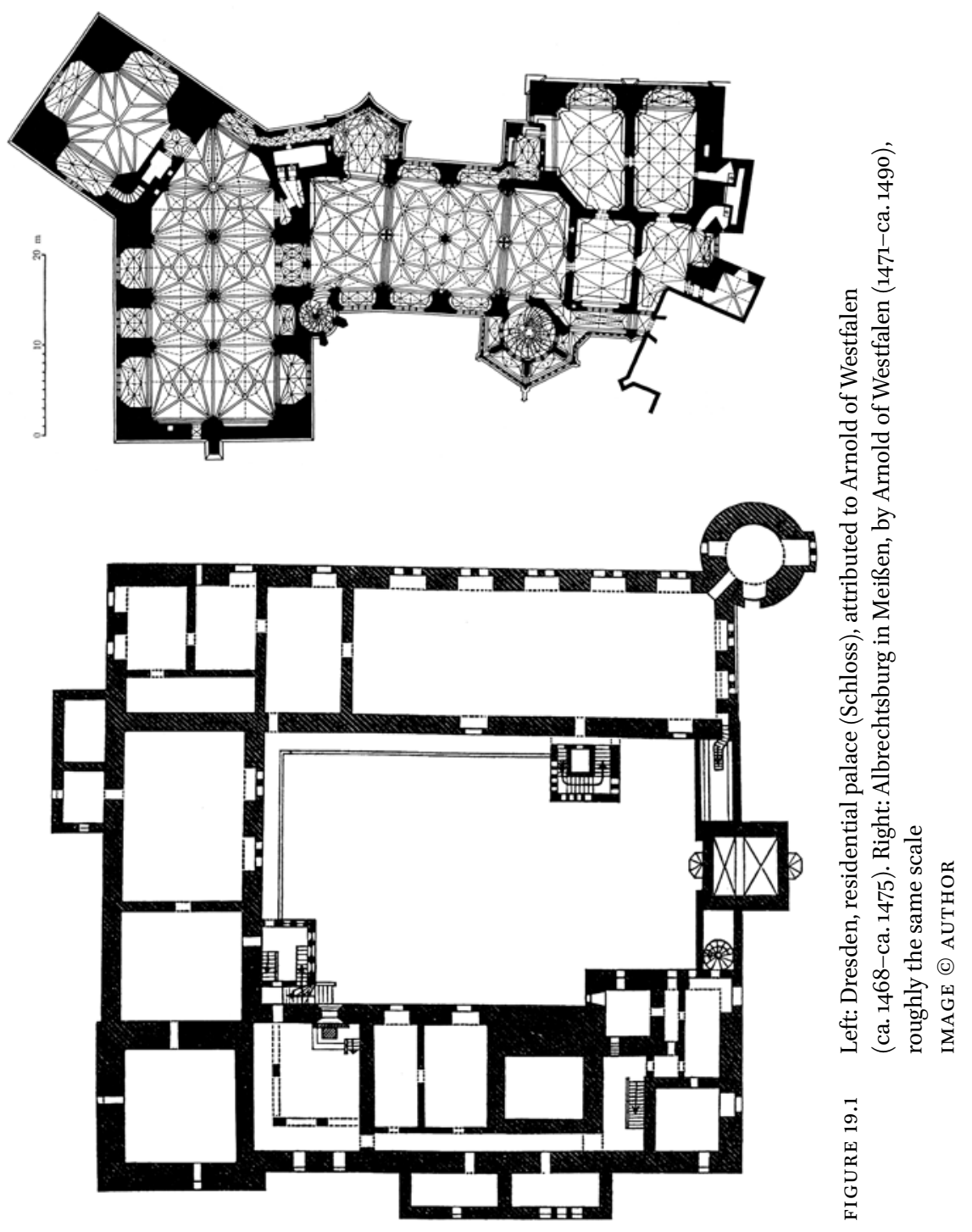


In 1468, the brothers Elector Ernest (1441-1486) and Duke Albert III (Albrecht) (1443-1500) of Saxony decided to transform the old Wettin castle in Dresden into a modern and up-to-date residence [Fig. 19.1 left]. ${ }^{5}$ The architecture of the renovated castle in the shape of a compact four-wing complex built around an inner courtyard on a quite regular plan was well able to integrate a range of diverse functions. It was also supposed to match current new ideals of courtly architecture as they were developing at the time throughout Europe. The castle was later rebuilt and enlarged. Nonetheless, its late fifteenth-century shape is well documented by a sixteenth-century wooden model, and it has also been quite well reconstructed by means of archaeological excavations in recent decades. ${ }^{6}$

Based on such information, an architectural ideal can be reconstructed at the Saxon court, the models for which probably ought to be sought out above all in the emergent duchy of Burgundy, which set new standards for the display of princely magnificence at the time. ${ }^{7}$ One of these particular models may have been the Palais Rihour, constructed from scratch from 1453 for Duke Philip the Good (1396-1467) in Lille, displaying a main stair turret on a square or rectangular ground plan, which we also find in Dresden. Other examples, such as the new stair turret added by Duke Charles the Bold (1433-1477) in 1468 to the Coudenberg Palace in Brussels or the splendid, today only partially preserved city palaces of the elites close to the court in Bruges and other Burgundian towns, may also have been highly influential in Saxony. ${ }^{8}$ Dresden

5 For a modern art historical survey about this era north of the Alps, see: DaCosta Kaufmann T., Court, Cloister, and City: The Art and Culture of Central Europe, 1450-1800 (Chicago: 1995). For a nuanced and useful explanation of the political background as well as of the various attempts at reform within the Holy Roman Empire, see the recent survey by Brady T.A., German Histories in the Age of Reformations: 1400-1650 (Cambridge - Leiden: 2009).

6 Oelsner N., "Die Errichtung der spätgotischen Schlossanlage (1468 bis 1480) und ihre weitere Entwicklung bis zur Mitte des 16. Jahrhunderts. Bauaufgabe - Strukturen - Befunde", in Landesamt für Denkmalpflege Sachsen (ed.), Das Residenzschloss zu Dresden, vol. 1: Von der mittelalterlichen Burg zur Schlossanlage der Spätgotik und Frührenaissance (Petersberg: 2013) 189-231.

7 On the residences in Lille, Ghent, and Brussels, see De Jonge K., "Bourgondische residenties in het graafschap Vlaanderen. Rijsel, Brugge en Gent ten tijde van Filips de Goede", Handelingen der Maatschappij der Geschiedenis en Oudheidkunde te Gent 54 (2000) 93-134. Heymans V. - Cnockaert L. - Honoré F. et al. (eds.), Le Palais du Coudenberg à Bruxelles. Du château médiéval au site archéologique (Brussels: 2014).

8 German scholarship generally tends to pick up French examples as models for the electoral Saxon palace architecture of the time. With regard to Dresden Castle, however, these influences cannot be traced, nor are they referenced in the extensive recent work of Norbert Oelsner. Oelsner lists the Coudenberg Palace in Brussels and the castles in Berlin and Innsbruck as reference objects: Oelsner, "Spätgotische Schlossanlage" 189-231. 
Castle, therefore, followed then-current northern European trends, which in principle still stylistically fit the tried-and-tested architectural traditions of the late Gothic. All'antica stylistic elements, which at the time had been developed in Italy for palace architecture, for example in Florence, Naples, or Urbino, cannot be detected in the original basic concept at Dresden.

The councillor and lord marshal of the Wettins Hugold of Schleinitz (1435-1490) imitated the concept and the stylistic orientation of the renovated electoral castle at Dresden when he undertook the modernization of his own country seat of Rochsburg, west of Dresden, from 1470 onwards. Hugold of Schleinitz was the highest-ranking superintendent of financial administration, of parts of the administration of the electoral court, and of foreign policy, and thus was a very powerful person. ${ }^{9}$ Therefore, it may be assumed that the modernization of the castles in Dresden as well as in Rochsburg followed to a substantial degree his own perceptions, shaped in accordance with international standards. In both cases, the electoral court architect Arnold of Westfalen (ca. 1425-1481) was probably responsible for the artistic realization, since Hugold expressly lauded his intellectual capacities. ${ }^{10}$

Only a year later, in 1471, the perceptions of ideal princely architecture had changed considerably at the Saxon court [Fig. 19.1 right]. An expression of this change is the Albrechtsburg above Meißen, started in that same year. ${ }^{11}$ Even

9 Streich B., Zwischen Reiseherrschaft und Residenzbildung. Der Wettinische Hof im späten Mittelalter (Cologne - Vienna: 989), for example 129.

10 For the rebuilding of Rochsburg Castle, begun in 1470 according to the bills preserved, Arnold of Westfalen is documented from the subsequent year in connection with the patron. Donath M., "Schloß Rochsburg und der sächsische Schloßbau des 15. und 16. Jahrhunderts", in Donath M. (ed.), Schloß und Herrschaft Rochsburg (Beucha: 2006) 59-75. Regarding Dresden, conceptually so similar, the leading role of Arnold from 1468 can only be assumed. On Arnold of Westfalen see Lemper E.-H., "Arnold von Westfalen. Berufs - und Lebensbild eines deutschen Werkmeisters der Spätgotik”, in Mrusek H.-J. (ed.), Die Albrechtsburg zu Meißen (Leipzig: 1972) 41-55 (on the hypothetical early work, today superseded); Bürger S., "Innovation als Indiz - Oeuvre und Ära der Amtszeit Arnold von Westfalens (1461/71 bis 1481)", in Bürger S. - Klein B. (eds.), Werkmeister der Spätgotik. Personen, Amt und Image (Darmstadt: 2010) 171-192; Bürger S., "Eine neue Idee zur Herkunft des Landeswerkmeisters Arnold von Westfalen", in Bärnighausen H. (ed.), Schlossbau der Spätgotik in Mitteldeutschland, conference volume (Dresden: 2007) 43-52; Donath M., "Meister Arnolds Familie. Arnold von Westfalen, Hans Rülcke und Claus Kirchner", Monumenta Misnensia. Jahrbuch für Dom und Albrechtsburg zu Meißen 8 (2007/2008) 103-107.

11 The most comprehensive survey of Meißen Castle is still the collection of essays published in 1972, which includes a comprehensive bibliography of the older literature: Mrusek H.J. (ed.), Die Albrechtsburg zu Meißen (Leipzig: 1972). In addition: Hoppe S., Die funktionale und räumliche Struktur des frühen Schloßbaus in Mitteldeutschland: untersucht an Beispielen landesherrlicher Bauten der Zeit zwischen 1470 und 1570 (Cologne: 1996) 
though the architect was again Arnold of Westfalen, who in the previous year had begun rebuilding the Rochsburg and who supposedly had devised three years previously the initial concept for Dresden Castle, ${ }^{12}$ the Albrechtsburg shows a very different architectural approach as well as a radically divergent formal language.

For example, contrary to Dresden or the Rochsburg, the Albrechtsburg is vaulted in all of its main storeys up to its eaves, in a remarkably elaborate and structurally challenging increase in levels of aspiration. ${ }^{13}$ In the majority of the rooms, a new type of vault without ribs was introduced - it was expressed either by a simple cruciform or through a more complicated star or web pattern (Zellengewölbe) [Fig. 19.2]. Recently, Stefan Bürger discussed very comprehensively the late-Gothic art of vaulting, which was then in its highly developed state in central Germany. ${ }^{14}$ In the Albrechtsburg, however, contrary to local as well as national traditions of late-Gothic masonry,

here in particular 34-77; Hoppe S., "Wie wird die Burg zum Schloss? Architektonische Innovation um 1470", in Laß H. (ed.), Von der Burg zum Schloss. Landesherrlicher und adeliger Profanbau in Thüringen im 15. und 16. Jahrhundert (Bucha bei Jena: 2001) 95-116; Donath M., "Herzog Albrecht der Beherzte und die Bauten auf dem Meißner Burgberg. Spätgotische Baukunst im ausgehenden 15. Jahrhundert", in Thieme A. (ed.), Herzog Albrecht der Beherzte (1443-1500). Ein sächsischer Fürst im Reich und in Europa (Cologne Weimar - Vienna: 2002) 233-281; Müller M., Das Schloßals Bild des Fürsten. Herrschaftliche Metaphorik in der Residenzarchitektur des Alten Reiches (1470-1618) (Göttingen: 2004), here in particular 42-66; and Bürger S., MeisterWerk Albrechtsburg. Von fürstlichen Ideen, faszinierenden Formen und flinken Händen (Dresden: 2011).

12 Whether Arnold von Westfalen really supervised the rebuilding of Dresden Castle from the beginning, i.e. from 1468 , is for the moment no more than a plausible conjecture. There is no other similarly qualified master worker traceable in the sources. Should new observations bring to light additional workplaces of Arnold around this time, it will become necessary to think anew about the creator of the Dresden designs.

13 As a rule, in the case of later castles that referred stylistically to the innovations of Albrechtsburg, a vaulting of the upper floors was renounced. An exception is the residential castle of the bishops of Meißen in Wurzen, with its large number of vaulted state rooms. A second exception to the rule is constituted by the rebuilding of the country house Sachsenburg for the electoral Saxon councillor and major domo Caspar von Schönberg (ca. 1430-1491) by an assistant of Arnold von Westfalen. The cell vaults planned here in 1485 up to the second storey for the princely accommodation were, however, only realized in part, cf. Schwabenicki W., "Das spätgotische Schloss Sachsenburg", in Bärnighausen, Schlossbau der Spätgotik in Mitteldeutschland 88-89.

14 Bürger S., Figurierte Gewölbe zwischen Saale und Neiße. Spätgotische Wölbkunst von 1400 bis 160o, 3 vols. (Weimar: 2007). Cf. also Müller W. - Quien N., Virtuelle Steinmetzkunst der österreichischen und böhmisch-sächsischen Spätgotik. Die Gewölbeentwürfe des Codex Miniatus 3 der Österreichischen Nationalbibliothek in Wien (Petersberg: 2005). See also Nußbaum N. - Lepsky S., Das gotische Gewölbe. Eine Geschichte seiner Form und Konstruktion (Munich - Berlin: 1999). Schröck K. - Wendland D. (eds.), Traces of Making. 


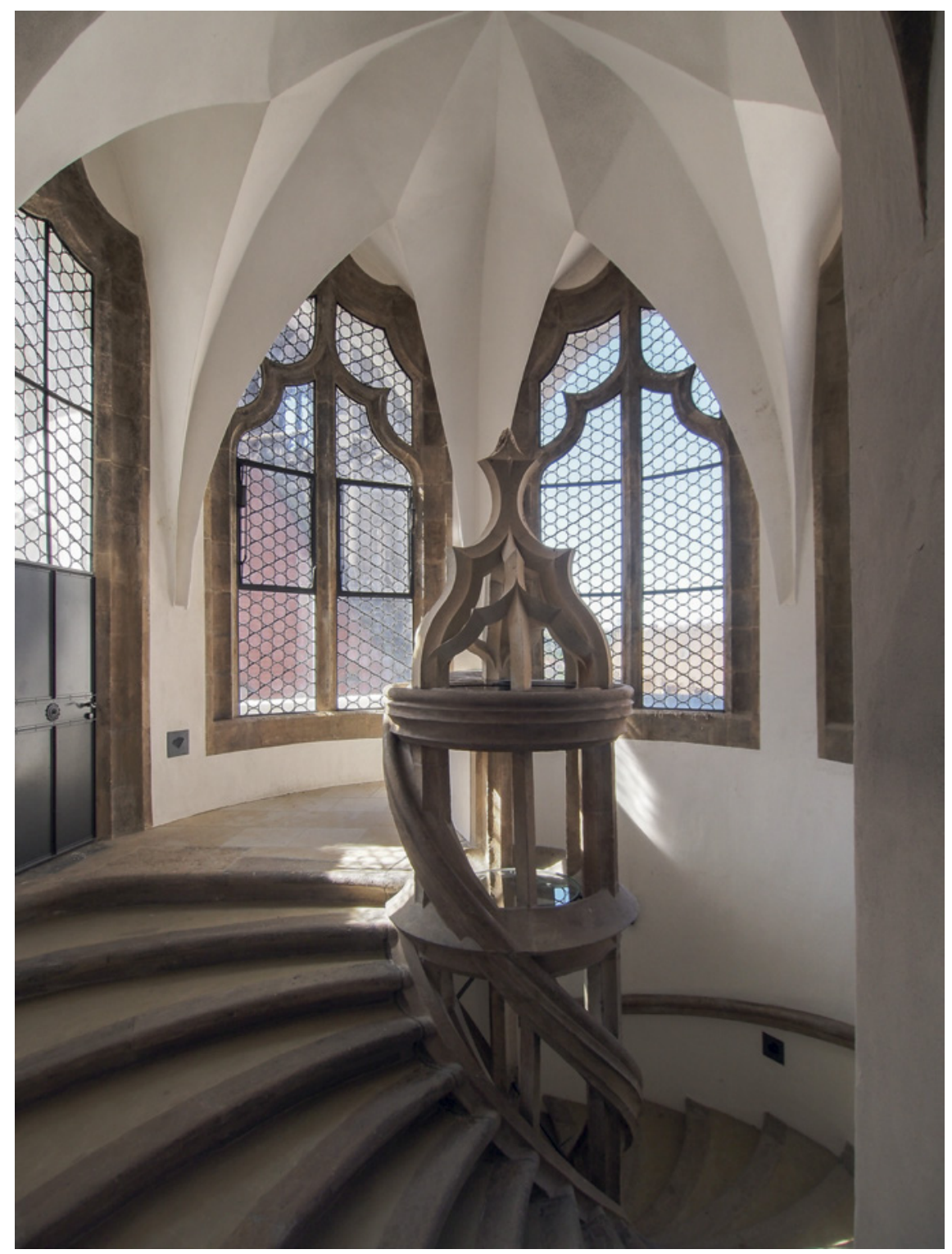

FIGURE 19.2 Arnold of Westfalen, Albrechtsburg in Meißen, Great Staircase Tower (ca. 1485) IMAGE (C) AUTHOR 
ribs were demonstratively forgone in nearly all the high-ranking staterooms. Some examples of this include the elector's apartment on the second floor (ca. 1477/1480), the Frauenzimmertafelstube (ladies' dining room, after 1480), ${ }^{15}$ the presumed state and guest apartments in the northeastern wing (during the phase of construction on the first floor, ca. 1480), ${ }^{16}$ or the Große Wendelstein (Great Staircase Tower, ca. 1485). ${ }^{17}$ Here, typical late-Gothic ground-plan patterns, with their artful geometrical complexity, connect to an innovative visual emphasis on the self-supporting shell (in the form of separate cells) and a visual preference for the load-bearing mass walls.

For a considerable amount of time, art historical scholarship has considered the reception of Romanesque vault architecture in connection with Meißen Castle. In 1972, Hermann Meuche proposed possible stimuli of this formal language to the debate:

We must - as suggested elsewhere - suppose that Arnold von Westfalen developed this new type of vaulting for Meißen Castle. Thus, from the beginning the aim obviously was to develop this type of vault without ribs (Gratgewölbe) [emphasis mine]. In any case, the web and star cells already appear without ribs in the rooms of the upper basement and on the ground floor. Such a rejection of the still mandatory Gothic ribbed vaults is meaningful. Perhaps the recollection of simple Romanesque vaults prompted this decision here in particular, where the sober function of the rooms called for a simple design. ${ }^{18}$

Equally, during the 1970s Milada Rada (Radová-Stiková) connected two further motifs typical of Meißen architecture to Romanesque models:

Entwurfsprinzipien von spätgotischen Gewölben. Shape, Design, and Construction of Late Gothic Vaults (Petersberg: 2014).

15 Hoppe S., "Bauliche Gestalt und Lage von Frauenwohnräumen in deutschen Residenzschlössern des späten 15. und des 16. Jahrhunderts", in Hirschbiegel J. Paravicini W. (eds.), Das Frauenzimmer. Die Frau bei Hofe in Spätmittelalter und früher Neuzeit (Stuttgart: 2000) 151-174.

16 Hoppe S., 'Der Raumtypus des 'Prunkappartements' als Träger symbolischen Kapitals. Über eine räumliche Geste der zeremonialen Gastfreundschaft im deutschen Schloßbau der beginnenden Neuzeit", in Hahn P.M. - Schütte U. (eds.), Zeichen und Raum. Ausstattung und höfisches Zeremoniell in den deutschen Schlössern der Frühen Neuzeit (Munich - Berlin: 2006) 229-251.

17 Harksen S., "Zum Bauverlauf auf der Albrechtsburg", in Mrusek, Albrechtsburg 31-34.

18 Meuche H., "Zellengewölbe und die Albrechtsburg", in Mrusek, Albrechtsburg 56-66, here 56. Translation Andrea Gáldy. 
It ought to be added that the low, triangular-shaped window lintel and the more innovative and more frequent inflexed arch (Vorhangbogen), which were characteristic for Arnold's architecture, were not taken from the level the Gothic stylistic development had reached at the time, neither were the spiral decorations of the shafts and pedestals. Both are new elements in contemporaneous Gothic, the analogy of which is rather to be found in Romanesque architecture. If we explain Arnold's rich artistic power of invention in part by his enthusiasm for the Romanesque style, it reduces by no means his merits in the field of architecture, since the transformation of the Romanesque elements in typical traits of his personal style was without doubt of great importance. The Renaissance of old forms was after all a typical procedure in the late fifteenth century, not only in Italy but also in other parts of Europe. ${ }^{19}$

Later on, Milada and Oldrich Rada repeated this thesis in a more nuanced version, this time in relation to Guelf Romanesque architectural models from the region of Brunswick:

At this time, spiral columns were not yet customary in the wider German territory. They were only present on old Romanesque buildings, for example in Brunswick, where the chapter house of the monastery of St. Ägidien has columns, the shafts of some of which are decorated with spiral lines. A two-nave Romanesque room with diversely decorated columns that are alternatingly provided with spiral lines has been preserved as part of the cloister in the nearby monastery of Königslutter. Perhaps the speculation that such Romanesque rooms inspired the architects of the late Gothic to use alternative forms of columns and to adopt spiral motifs on the columns' shafts should not be rejected..$^{20}$

At this point it ought to be added that at the same time, around 1470/1475, a ground floor hall (probably the new Hofstube/ceremonial dining hall) in the eastern wing of Dresden Castle, then already under construction, was refurbished with a new brick vault of this new type [Fig. 19.3]. In the guise of a two-nave groin vault with a simple ground plan, the new Dresden hall follows Romanesque architectural solutions more closely than the more complex

19 Radová-Stiková M., "Über die Quellen des architektonischen Schaffens Arnold von Westfalen”, Acta Polytechnica 1 (1974) 29-50, esp. 45; translation Andrea Gáldy.

20 Radová M. - Rada O., Das Buch von den Zellengewölben (Prague: 2001) 20-21. 


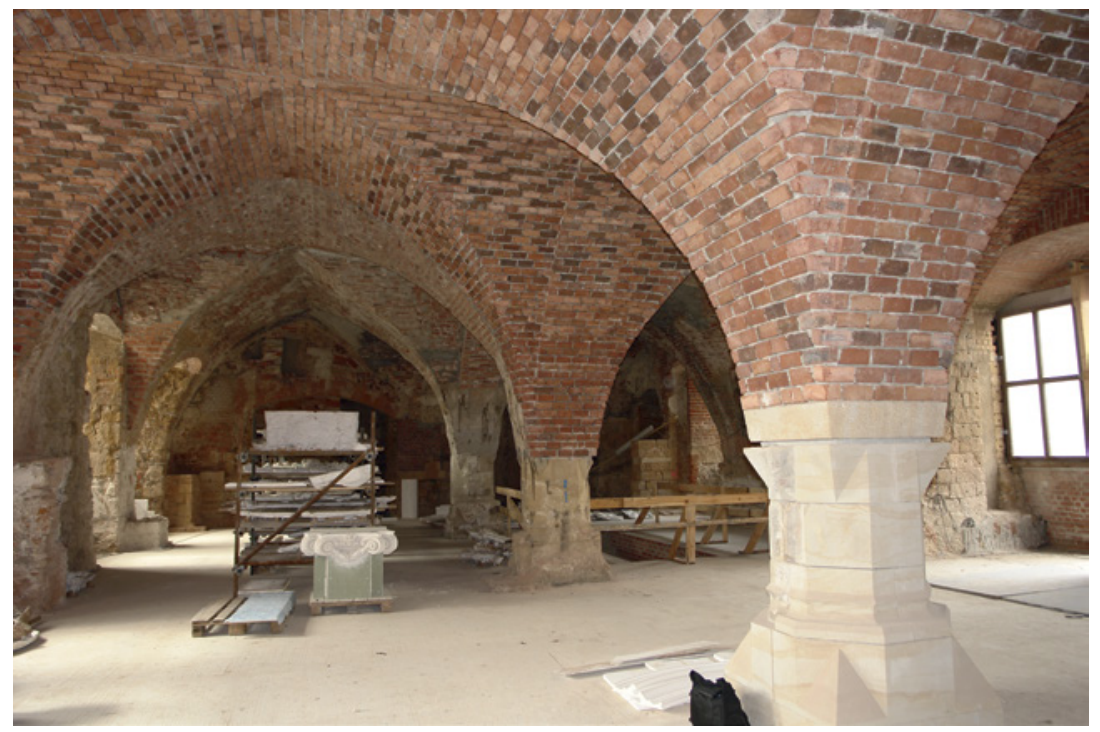

FIGURE 19.3 Arnold of Westfalen (attributed), Dresden, Schloss, ground floor hall of the east wing with its Romanesque Renaissance vault, so called "Gotische Halle" (ca. 1470-1475)

IMAGE (C) LANDESAMT FÜR DENKMALPFLEGE SACHSEN

figured vaults of the upper storeys of Albrechtsburg do, the latter being realized only from the fiscal years of $1476 / 1477 \mathrm{on} .^{21}$

The older and initial basement vaults in Meißen, to the contrary, follow the neo-Romanesque pattern in Dresden much more closely [Fig. 19.4 top]. In particular, the first batch of unribbed groin vaults that may be attributed to Master Arnold ca. 1471 obviously followed typical Romanesque interior designs [Fig. 19.4 bottom] more closely than the later and art historically better-known cell vaults, with their obvious additional and hybrid references to the highly complex art of late-Gothic net and star vault patterns.

A further observation may underpin the experimental status of the new Saxon vault style: current building-archaeological research has proposed the chronologically precedent renovation of the princely accommodation on the second floor of the electoral castle of Rochlitz on the Zwickauer Mulde as the experimental prototype for the more complex figured cell vaults (Zellengewölbe) of the Meißen upper storeys from 1476/1477 on. ${ }^{22}$

\footnotetext{
21 Harksen, "Zum Bauverlauf auf der Albrechtsburg" 31-34.

22 The Rochlitz renovation with cell vaults in the window niches and other small vaults in the new style was dated by Reuther by dendrochronology of the floor beams to the years 1472/1473 (Reuther S., "Bautätigkeit auf Schloss Rochlitz in der zweiten Hälfte des 15.
} 

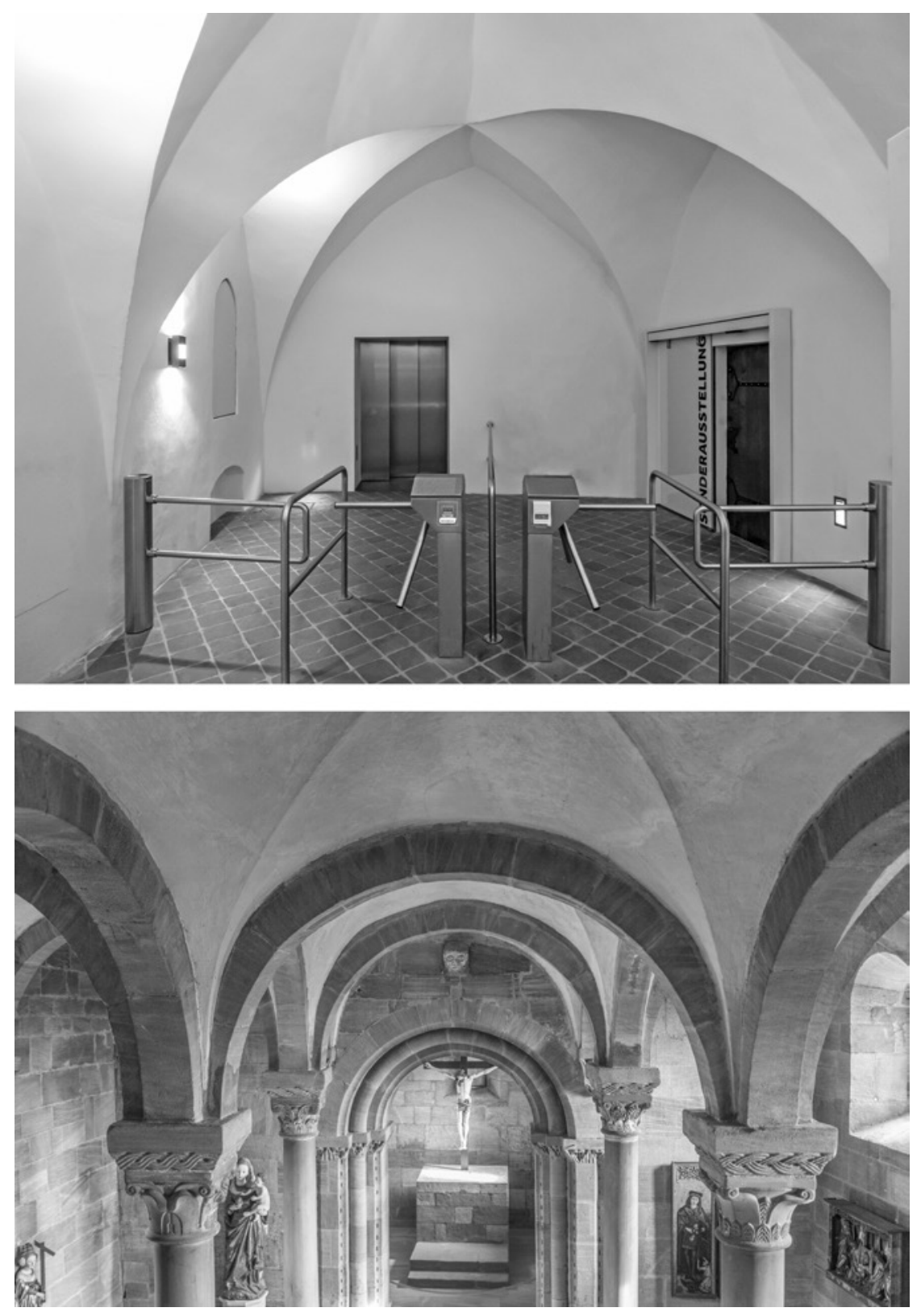

FIGURE 19.4 Top: Arnold of Westfalen, Albrechtsburg in Meißen, ground floor room (ca. 1475). Below: Upper Chapel of the Kaiserburg at Nuremberg, in the

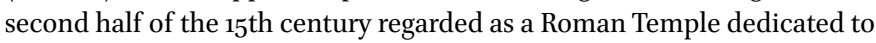
Diana (in reality built ca. 1200) TOP IMAGE (C) AUTHOR; BOTTOM IMAGE (C) TILMAN2007 WIKIMEDIA CC BY-SA 4.0 


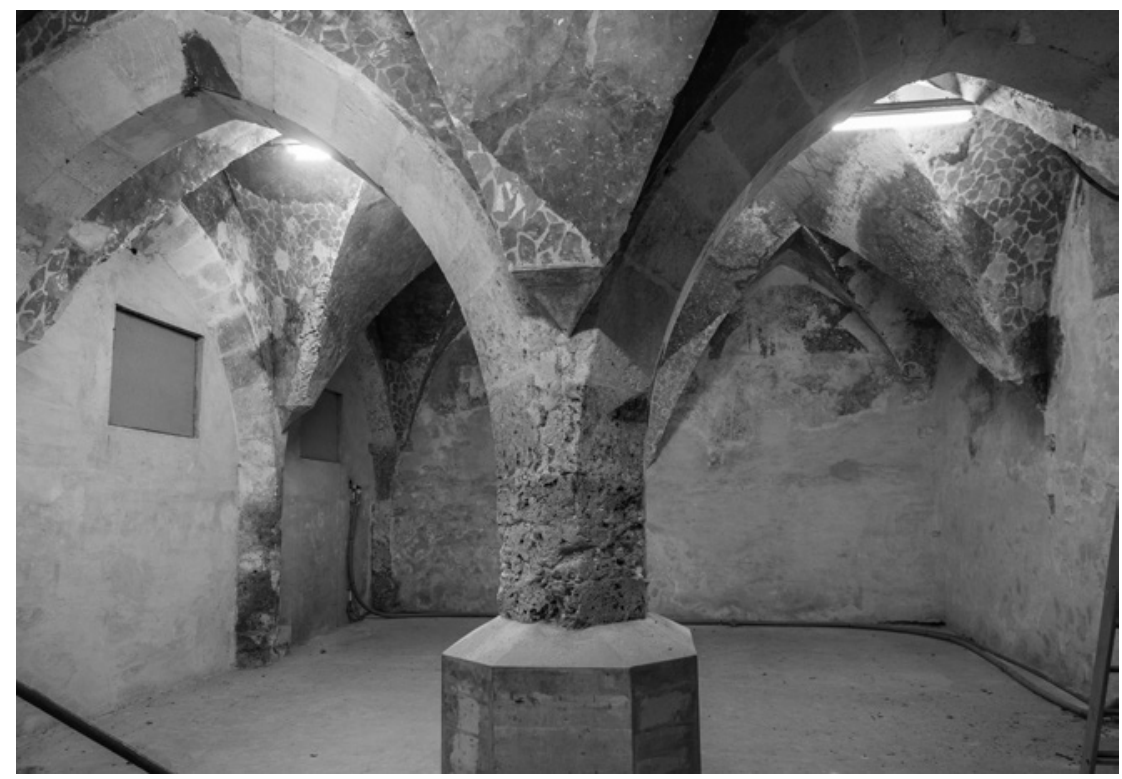

FIGURE 19.5 Graz Castle, ground floor hall, "Einstützenhalle" (ca. 1460-1470)

IMAGE (C) AUTHOR

But it was not only in the Saxon towns of Meissen, Dresden, and Rochlitz that new architectural motifs appeared from ca. $1471 \mathrm{on}$. Only a little later, northern Alpine architecture created additional high-quality buildings which adopted stylistic elements of Romanesque interior architecture and more or less transformed them. Particularly important seem those edifices in which the reception is stylistically even more closely linked to the historical models from the Romanesque era than is the case in the works of Arnold von Westfalen.

Unfortunately, it is not quite clear at the moment whether two monumental vaults without ribs on the basement floor of the imperial castle at Graz (Styria) (Einstützenhalle and Dreistützenhalle) predate or postdate the Dresden exemple [Fig. 19.5]. The similarity in position and overall stylistic approach of the unribbed groin vaults in Graz and Dresden is striking. Local art historical experts date the Graz vaults to the midway through the reign of Emperor Frederick III of Habsburg into the 146os, and we may have here an initial experiment with the reception of Romanesque architecture at the imperial court

Jahrhunderts", in Staatliche Schlösser, Burgen und Gärten Sachsen, Schlossbau Spätgotik 146-154). This dating is not undisputed, as David Wendland and Günther Donath prefer a slightly later date, around 1480 , for this vaulting campaign. 


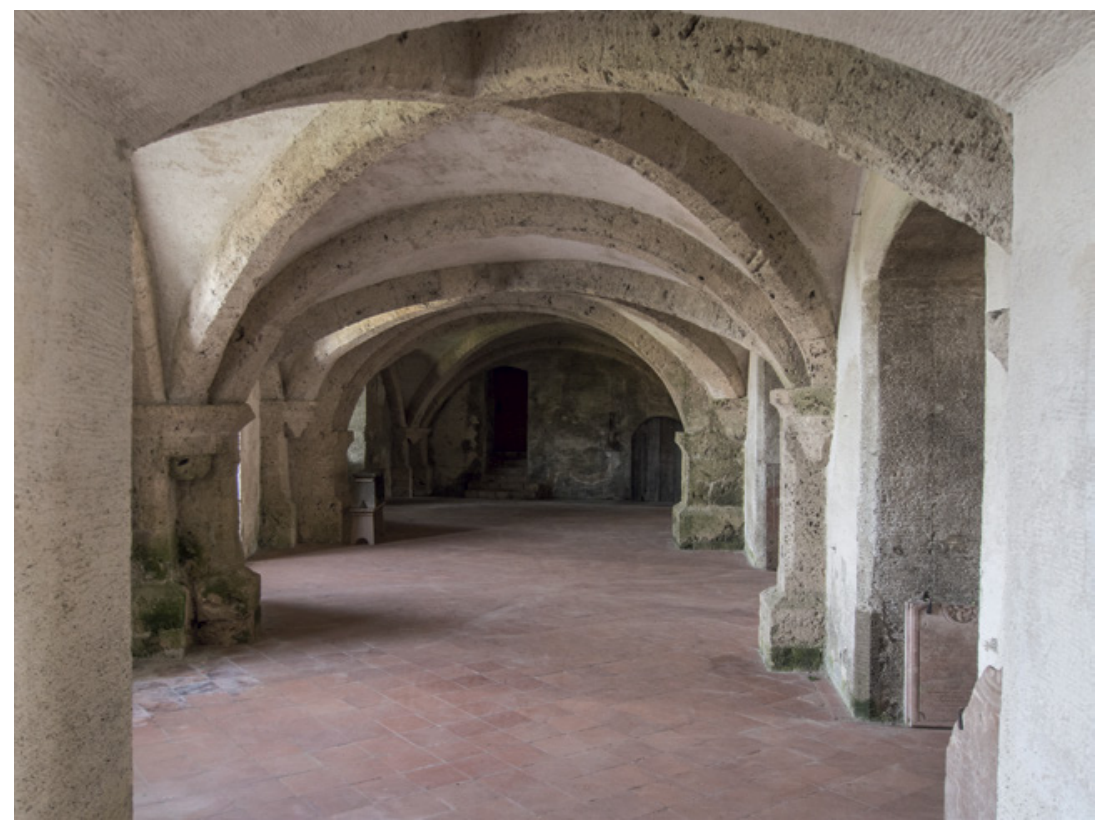

FIGURE 19.6 Ulrich Pesitzer (attributed), Burghausen (Bavaria), ground floor hall with a Romanesque Renaissance vault (ca. 1480)

IMAGE (C) AUTHOR

that soon became a meaningful role model for some of the following princely building projects. ${ }^{23}$

Another prominent example of this new type of prominent vaults with Romanesque features is the vaulted hall on the ground floor of the palas constructed from ca. 1480 at the secondary residence of the dukes of BavariaLandshut in Burghausen [Fig. 19.6]. ${ }^{24}$ Again, we see an example of the courtly ambience of this period. The new Burghausen palas has a vaulted ground floor,

23 Absenger W. - Legen M., "Die Grazer Burg und Residenz in der Zeit Friedrichs III. und Maximilians I. Erkenntnisse und Fragestellungen zur Baugenese des 15. und frühen 16. Jahrhunderts", in Becker U. et al. (eds.), Ich hab das selbig paun lassen. Beiträge zur Kunst der Spätgotik in der Steiermark (Graz: 2011) 20-55.

24 Hoppe S., "Die Residenzen der Reichen Herzöge von Bayern in Ingolstadt und Burghausen. Funktionale Aspekte ihrer Architektur um 1480 im europäischen Kontext”, in Schmid A. Rumschöttel H. (eds.), Wittelsbacher-Studien. Festgabe für Herzog Franz von Bayern zum 8o. Geburtstag, Schriftenreihe zur bayerischen Landesgeschichte 166 (Munich: 2013) 173-200; Langer B., Burg zu Burghausen. Amtlicher Führer (Munich: 2004). For a survey of the cultural politics at the Landshut court see Niehoff F. et al. (eds.), Ritterwelten im Spätmittelalter. Höfisch-ritterliche Kultur der Reichen Herzöge von Bayern-Landshut, exh. cat., Museen der Stadt Landshut (Landshut: 2009). 
in which four areas with seemingly massive cross-ribbed vaults with ribbontype ribs (Bandrippen) form one connected hall-type room. The vaulted interior so closely follows a (late) Romanesque architectural language that it had indeed been misdated to the thirteenth century by regional scholarship. ${ }^{25}$ The examination of the stone surfaces and of the conceptual connection with the early Renaissance apartment plan in the two princely living quarters above attests to the construction from ca. 1480 onwards. ${ }^{26}$

Whether the Lower Bavarian court architect Ulrich Pesnitzer (ca. 14501521), who was also in charge of enlarging the fortifications in Burghausen, was the architect responsible for the vault design cannot be ascertained for the moment. ${ }^{27}$ It is, however, rather conspicuous that the inner court chapel of Burghausen Castle, next to the palas, which was rebuilt at the same time or a little bit later, shows both typical modern rib vaults in the nave and groin vaults without ribs in the Romanesque style under the ducal gallery [Fig. 19.7]. In this case, the exact time of construction still needs to be verified. There is much evidence in favour of dating the gallery to the building period between 1480 and 1490.

It is perhaps not by chance that the Burghausen building project, with its demonstrative reception and integration of Romanesque vaulting styles, belongs in the context of the Lower Bavarian court of the Wittelsbachs, who after all were closely related by marriage to the electoral court of Saxony. Building patrons in Burghausen were Duke George the Rich $\left(1455^{-1503)}\right.$ and his bride Duchess Hedwig Jagiellon (1457-1502), who descended from the Polish royal family. Duke George's mother and Hedwig's mother-in-law, Amalie of Saxony (1436-1501), was the sister of the two princely building patrons in Dresden, Meißen, and Rochlitz.

In the ambience of the Landshut court belongs, probably, another vaulted gallery in the new style that is set inside a church building. The three-nave west gallery with two bays and its vault without ribs in the style of this Romanesque Renaissance was created, probably during the last quarter of the fifteenth

25 Landgraf A., "Mittelalterliche Holzeinbauten in der Burg zu Burghausen", Burgen und Schlösser 22, 2 (1981) 108-111.

26 I wish to express my thanks to Alexander Wiesneth, Krista De Jonge, Konrad Ottenheym, Barbara Archizewska, Christa Syrer, and Magdalena März, who discussed and shared my redating on two visits on-site. Further investigations of the Burghausen architecture are planned in future.

27 Hoppe S., "Baumeistervon Adel. Ulrich Pesnitzer und Hans Jakob von Ettlingen als Vertreter einer neuartigen Berufskonstellation im späten 15. Jahrhundert”, in Lang A. - Jachmann J. (eds.), Aufmaß und Diskurs. Festschrift für Norbert Nußbaum zum 6o. Geburtstag (Berlin: 2013) 151-186. 


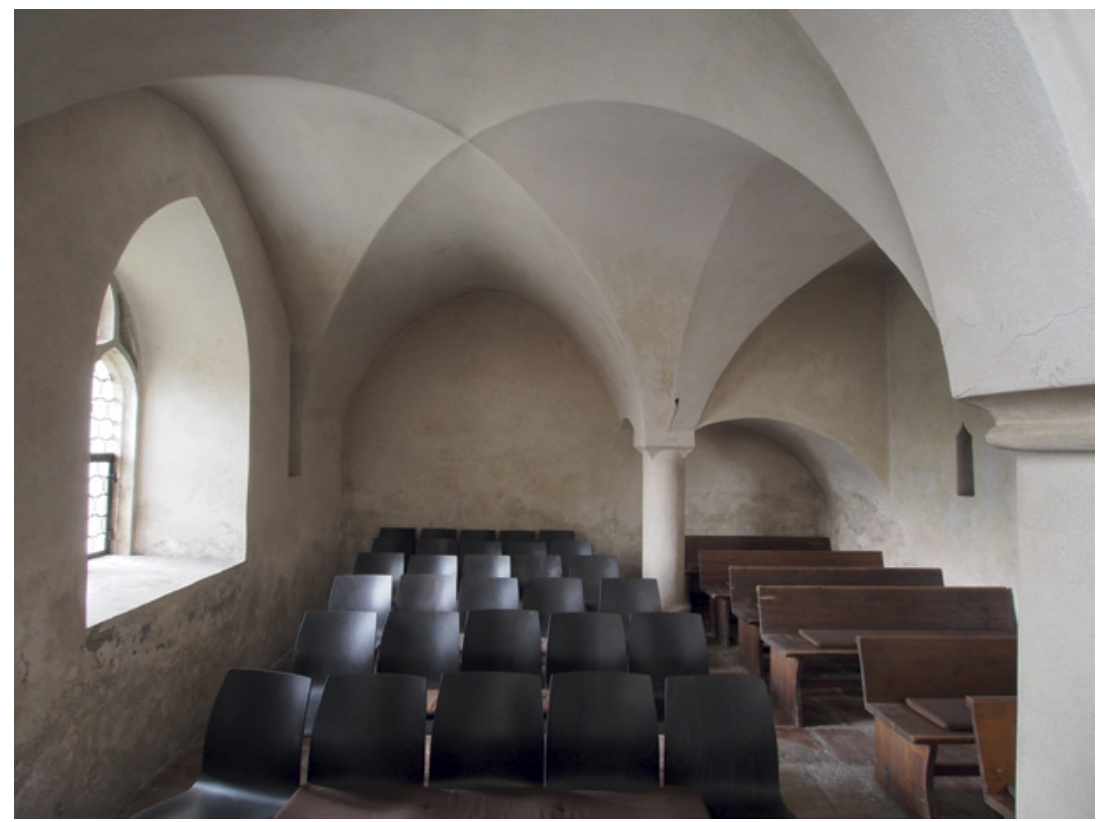

FIGURE 19.7 Ulrich Pesitzer (attributed), Burghausen (Bavaria), inner Palace Chapel with the Romanesque Renaissance vault of the ducal gallery (ca. 1480-1490) IMAGE (C) AUTHOR

century, in the thirteenth-century collegiate church of Moosburg. ${ }^{28}$ The collegiate chapter situated ca. $20 \mathrm{~km}$ west of Landshut maintained close connections to the Lower Bavarian ducal court.

Also belonging to the group of princely German buildings which during the last third of the fifteenth century adopted stylistic features of the Romanesque era and integrated them into the current architectural culture, is the renovated archiepiscopal palace of Hohensalzburg, not far from Burghausen [Fig. 19.8]. But this renovation did not happen during the well-known phase of construction of the staterooms, which consisted of the creation of the carved chamber and its neighbouring bedroom in a sumptuous and modern late-Gothic style ca. $1500,{ }^{29}$ but concerns a slightly older campaign of the monumental staircase and its vaulted hall that is reminiscent of Romanesque models.

28 Außermeier M. - Hentschel C., Kastulusmünster Moosburg (Lindenberg: 2016). Cf. Weber H., 'Mausoleum Stat in medio Chori' Zum Bildgebrauch in Kollegiatstiftskirchen im Mittelalter, dargestellt am Beispiel des Moosburger Hochaltars von Hans Leinberger, Ph.D. dissertation (Otto-Friedrich-Universität Bamberg: 2006).

29 Riegel N., "Die Fürstenzimmer auf Hohensalzburg - Ausstattungsluxus und Repräsentation um 1500", Münchner Jahrbuch für bildende Kunst 66 (2015) 23-74. Also 


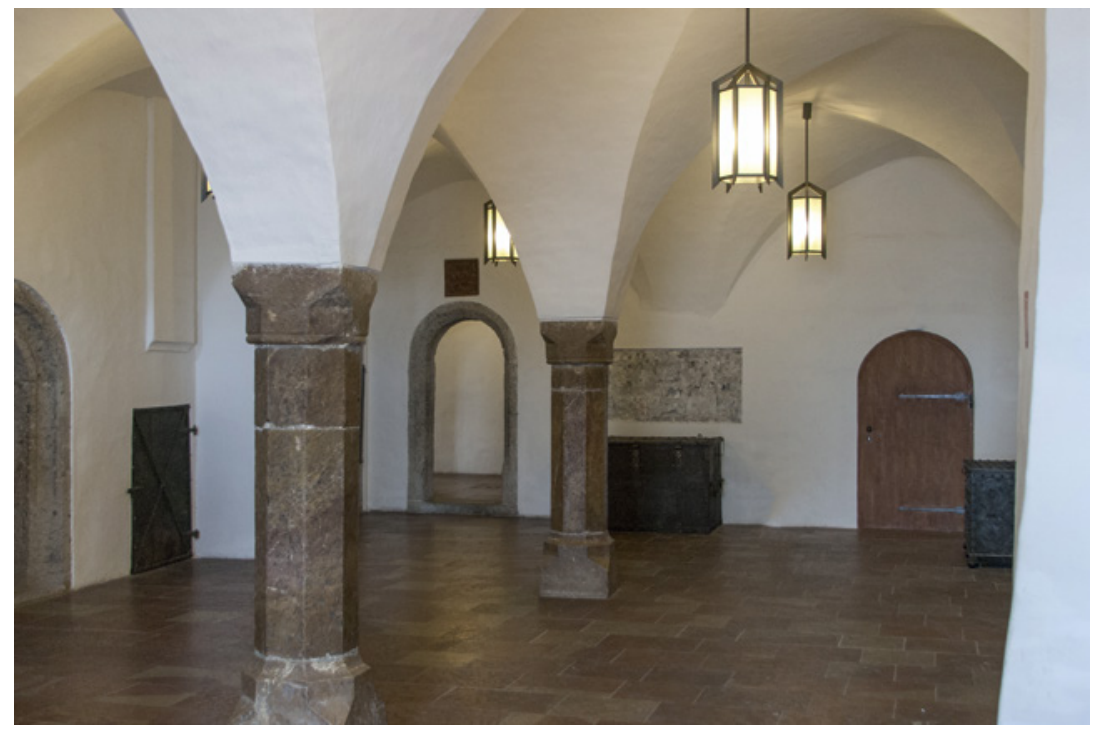

FIGURE 19.8 Hohensalzburg Palace at Salzburg, central staircase hall with a Romanesque Renaissance vault (ca. 1480-1485) IMAGE (C) AUTHOR

Traditionally, this older building Salzburg project with its distict Romanesque stylistic features, which also include the rounded arches of the new doorways, is ascribed to Archbishop Johann III of Gran/Esztergom (Johann Beckenschlager, r. ${ }^{1485}-1489$ ), and therefore dated to the mid 1480 s. $^{30}$ A further candidate for the building's patronage might have been his predecessor, Archbishop Bernhard of Rohr (r. 1468-1482/1485), a prince of the church particularly devoted to humanism and to the arts, whose personal passion for architecture and other art projects is much better documented than that of his successor. Rohr's wide-ranging network included the neighbouring Wittelsbach court in Landshut, where in 1475 he had united in matrimony the princely couple of George and Hedwig. Rohr's bailiff in Salzburg, chancellor, and personal

cf. Riegel N., Die Bautätigkeit des Kardinals Matthäus Lang von Wellenburg (1468-1540) (Münster: 2009); Riegel N., "Hohensalzburg unter Leonhard von Keutschach und Kardinal Matthäus Lang von Wellenburg. Fortifikation und Repräsentation 1495-1540", in Lieb S. (rev.), Burgen im Alpenraum, Forschungen zu Burgen und Schlössern 14 (Petersberg: 2012) 95-109.

$30 \quad$ Schicht P., Bollwerke Gottes. Der Burgenbau der Erzbischöfe von Salzburg (Vienna: 2010) 103-113, on the enlargement during the second half of the fifteenth century. Schicht, like the older literature, ascribes the vaulting of the staircase halls because of the coat of arms on a door lintel to Archbishop Johann III of Gran. 
confidant was the Chiemsee bishop Georg Altdorfer (1437-1495), a man from a Landshut patrician family who had received his doctorate in Bologna. In Landshut, his sculptured marble tomb is preserved in the Altdorfer family's chapel; its unribbed groin vault and ornamented, sturdy column shafts clearly allude to Romanesque architectural motifs, and this represents a Romanesque Renaissace work in a related discipline. ${ }^{31}$

It is not only in diverse places within the framework of Central European courtly architecture that one can observe, during the final third of the fifteenth century, a new interest in stylistic features of Romanesque architecture. A rather particular example of Romanesque revival is offered by the interior architecture of a private chapel in Bruges [Fig. 19.9]. The merchant and diplomat of Italian origins Anselm Adornes (Adorno) (1424-1483) had it built as part of his city palace and dedicated it to the Holy Sepulchre in Jerusalem. The patron was closely connected to the Burgundian court and entertained contacts with artists, such as Hugo van der Goes (1430/1440-1482), and eminent humanists, such as Filippo Buonaccorsi (1437-1497). Construction of the Jerusalem Chapel was started in 1471, directly after the return of Adornes from the Holy Land. It was structurally completed on his death in 1483 at the latest. ${ }^{32}$

In accordance with the patrocinium, the Bruges chapel consists of a soaring central building with a single-aisled nave in front. The polygonal choir is superelevated by means of four squinches (actually, this was also a typical motif of the Romanesque style) to a high tambour on a polygonal plan, which terminates above the clerestory with a wooden rib vault. The ribs are underpinned by ten engaged columns, the proportions and diversely decorated shafts of which

31 Niehoff F. - Tewes M., "Epitaph des Dr. Georg Altdorfer" cat. no. 54, in Niehoff F. (ed.), Vor Leinberger Landshuter Skulptur im Zeitalter der Reichen Herzöge 1393-1503 (Landshut: 2001) 404-407; Halm P.M., "Hans Beierlein", Münchner Jahrbuch der bildenden Kunst 6 (1911) 27-6o, here 34; Liedke V., Zum Leben und Werk des Bildschnitzers Hanns Peurlin des Mittleren, dem Meister von Bischofsgrabdenkmälern in Augsburg, Eichstätt und Freising, Die Augsburger Sepulkralskulptur der Spätgotik 3 (Munich: 1987), here cat. no. 12, 42-49. Made by the second Beierlein/Peurlin (ca. 1440-ca. 1507) or his Augsburg family workshop are also a number of artistically ambitious tombstones of personalities of humanistic backgrounds (like Wilhelm of Reichenau) from Augsburg and Eichstätt, which have Renaissance Romanesque architectural elements.

32 Catalogue entry by Esther J.P. in Geirnaert N. - Vandewalle A. (eds.), Adornes and Jerusalem: International Life in 15th-and 16th-Century Bruges (Bruges: 1983) 51-80. Cf. Dikken C., "A Monument to a Glorious Past and a Questionable Future? The Jerusalem Chapel in Bruges and its Stained-Glass Windows", in Weijert-Gutman R. - Ragetli K. (eds.), Living Memoria: Studies in Medieval and Early Modern Memorial Culture in Honour of Truus van Bueren, Middeleeuwse studies en bronnen 137 (Hilversum: 2011) 79-96, 420421. I would like to express my gratitude to Krista De Jonge for drawing my attention to this building and for opening its doors for me. 


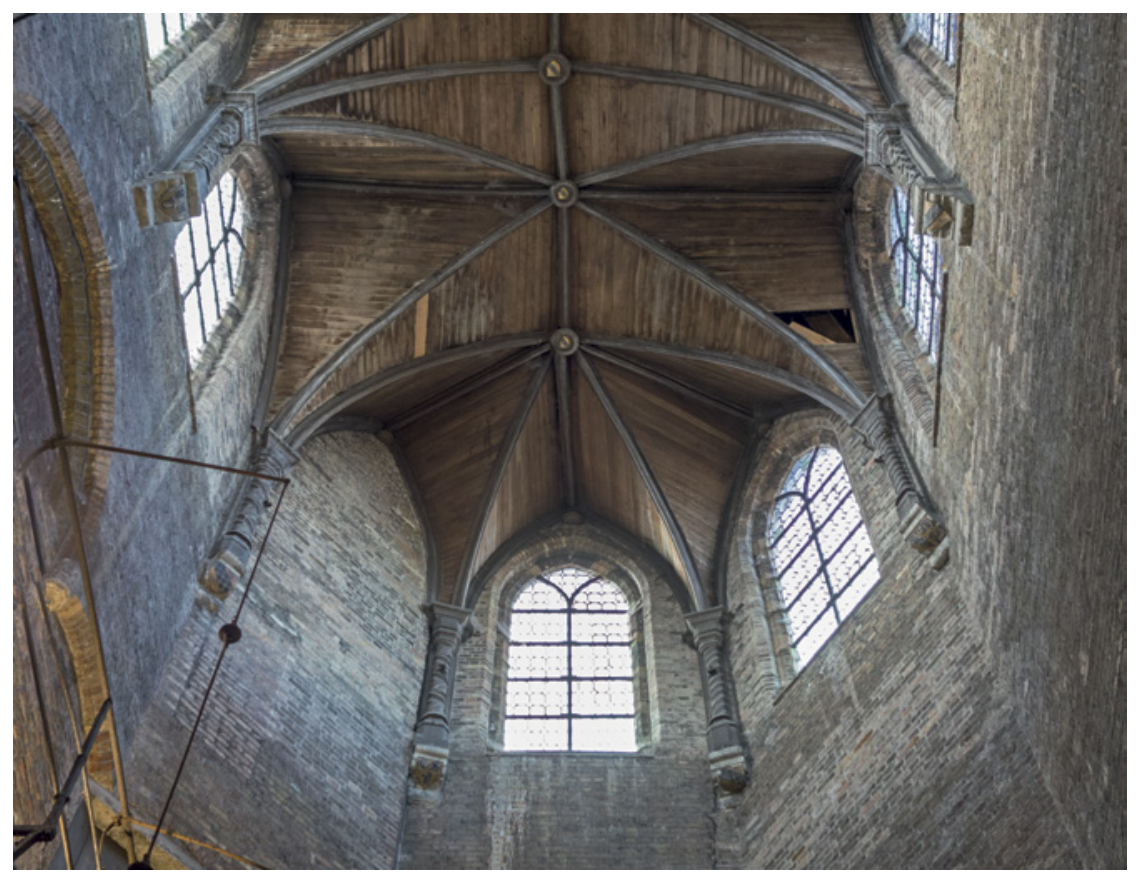

FIGURE 19.9 Jerusalem Chapel in Bruges (ca. 1470-1483)

IMAGE (C) KRISTA DE JONGE

closely follow Romanesque examples. The Jerusalem Chapel is lit by a mixture of ogival windows with much reduced tracery in the tambour and large, round oculi. The building therefore adopts typical motifs of the Romanesque architectural sculpture as well as typical construction ideas of the older period. The point of departure for these stylistic allusions would have been the reference to the patrocinium of the Holy Sepulchre church, built and renovated in antiquity and then again modernized during the Romanesque era.

Another project from a sacred context is the newly constructed cloister of ca. $1470-1480$ of the Westphalian monastery at Dalheim, refounded in 1460 at a new location [Fig. 19.10]. ${ }^{33}$ In this case, and contrary to the example at Burghausen, a different strategy of vaulting inspired by the Romanesque was chosen, by adding stuccoed groins and braided ornaments to the relatively simple, if monumental, groin vaults. The large, concavely settling cells that had thus been created were from the beginning destined for painted decoration. Here as well, a spatial impression came into being that had no equivalent in

33 Pieper R., Dalheim. Pfarrort - Kloster - Staatsdomäne (Münster: 200o), on the cloister see $65^{-78 .}$ 


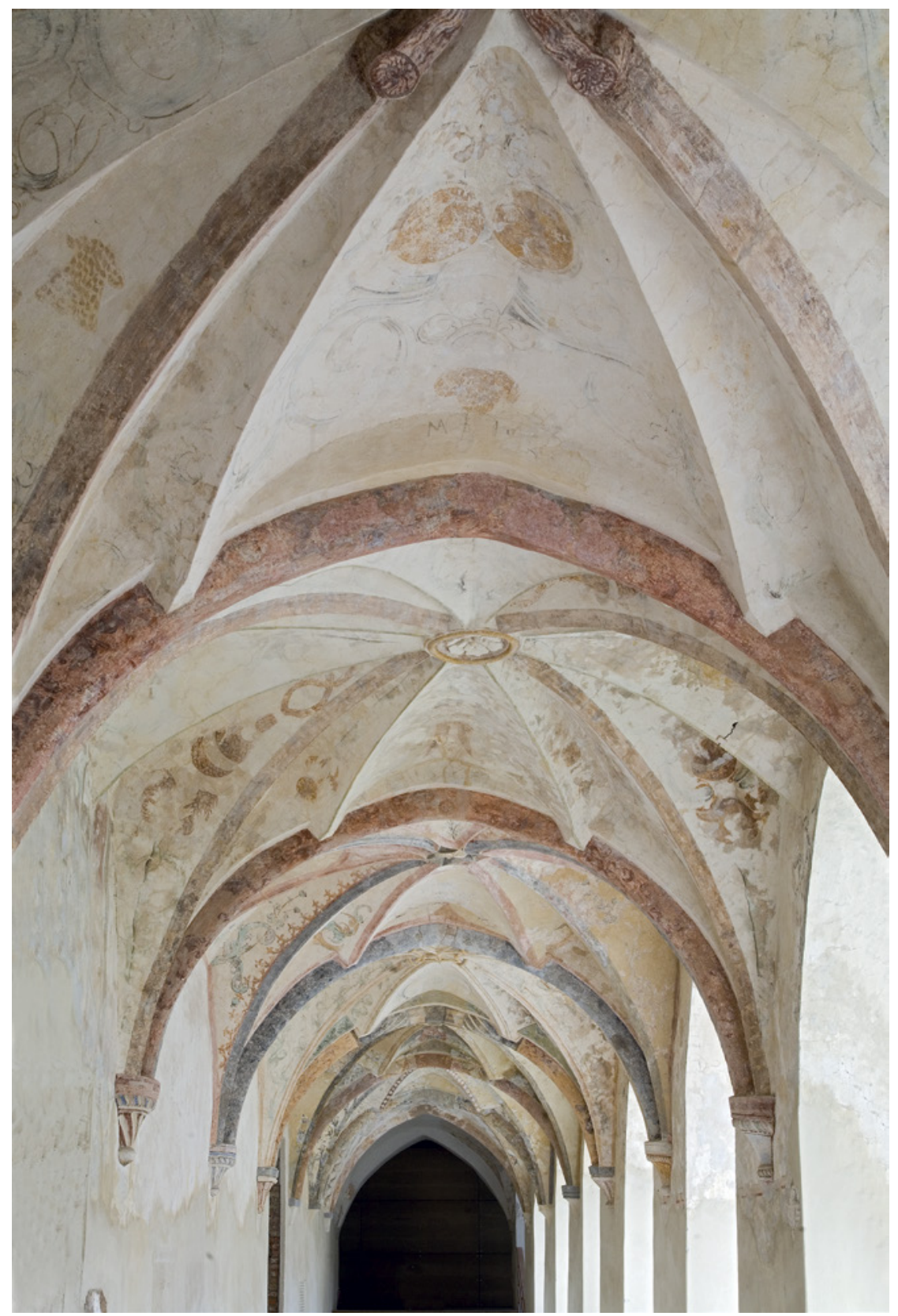

FIGURE 19.10 Dalheim monastery (Westphalia), cloister (ca. 1470-1480) IMAGE (C) AUTHOR 
coeval Gothic architecture and that needed the detailed study of Romanesque buildings and of respective ornamental techniques as its prerequisites.

It almost seems as if the current trends of monastic reform and the humanistic thought often connected to it had prepared the ground within the monastic sphere for architectural stylistic experiments with respect to Romanesque models in German. The Cistercian monastery of Bebenhausen, near Tübingen, in Swabia was very close to the ducal and later comital family of Württemberg during the final decades of the fifteenth century. Count Eberhard the Bearded (Eberhard I of Württemberg, 1445-1496) had gathered a great number of scholarly people close to the ideas of humanism for the intended reform of his territory. ${ }^{34}$ His abbots also played a major role in the neighbouring, sovereign University of Tübingen, which had rather early on turned into a trading point for humanist ideas.

Shortly before $1500,{ }^{35}$ in Bebenhausen the so-called Laienrefektorium (lay refectory) was created by the mastermason and architect Johann of Bebenhausen; it was a vaulted hall spanning twelve bays in the west wing of the cloister, and it obviously referred back to older vaulted rooms in the thirteenth-century part of the monastery [Fig. 19.11]. Their heavy-set and sculptural forms were revisited in general, while single details were adapted in such a way that their creation within the context of design trends current during the fifteenth century can be perceived. Constructed contemporaneously were the vaults of the neighbouring western whing of the Bebenhausen cloister, designed and manufactured by the same architect and his masons but here in the modern forms of Gothic style. It is a particular feature of this architect and his masons that they were able to work in two different styles and think in the stylistic language of an older architecture.

This microhistory of different examples from the early phase of an innovative reception of Romanesque architecture in the fifteenth century already indicates the diversity of reception strategies and architectural approaches that were at the disposal of architects and patrons. The phenomenon of the Romanesque Renaissance can be traced well into the sixteenth century and

34 Mertens D., "Eberhard im Bart und der Humanismus", in Maurer H.M. (ed.), Eberhard und Mechthild. Untersuchungen zu Politik und Kultur im ausgehenden Mittelalter (Stuttgart: 1994) $35^{-81 .}$

35 On the issue of dating cf. Knapp U., "Zentraler Erschließungsraum und Ort klösterlicher Repräsentation. Neue Untersuchungen zur Baugeschichte des Kreuzgangs der Zisterzienserabtei Bebenhausen", in Beuckers K.G. -Peschel P. (eds.), Kloster Bebenhausen. Neue Forschungen. Tagung der Staatlichen Schlösser und Gärten Baden-Württemberg und des Kunsthistorischen Institut der Christian-Albrechts-Universität zu Kiel am 30. und 31. Juli 2011 im Kloster Bebenhausen (Bruchsal: 2011) 43-78. 


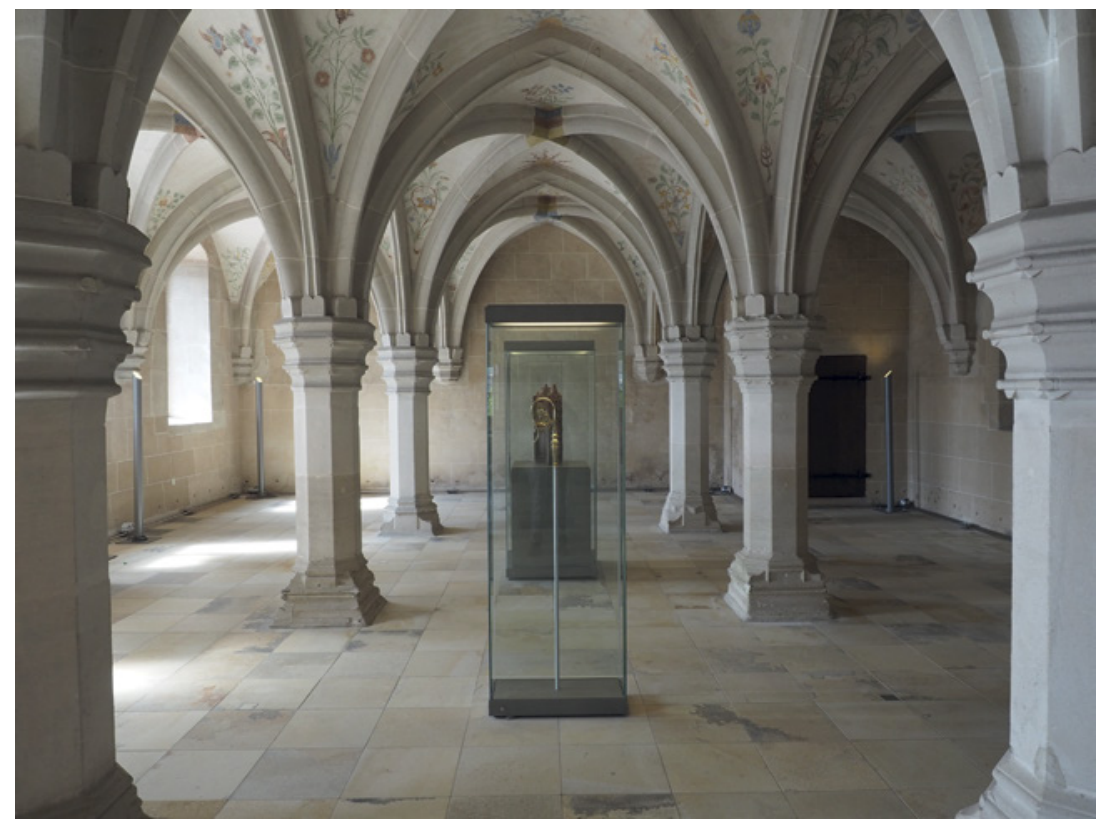

FIGURE 19.11 Johann of Bebenhausen, Bebenhausen monastery (Swabia), so called "Laienrefektorium" (ca. 1495-1500)

IMAGE (C) THE AUTHOR

can be observed in other European regions; for reasons of space, a detailed debate is omitted here. ${ }^{36}$

All of the examples presented thus far have in common that they adopted from a certain starting point, around 1470, stylistic elements which can be ascribed art historically to the pre-Gothic architecture of the Romanesque period. It remains to be seen, however, which specific Romanesque models possibly served artists and patrons for orientation. The reception of Romanesque architecture is so generic in the case of the buildings mentioned thus far that although it can be recognized today by means of art historical style analysis, it cannot be used to classify them as copies or revivals of particular edifices (except for Bebenhausen). That is an important observation in itself, since it attests to a new appreciation of a previously existing architectural era as a different style in general.

In what follows, I shall attempt to identify some particular local or regional Romanesque buildings that had individually attracted the attention of

${ }_{36}$ For some examples of the sixteenth century in the regions north of the Alps, see Hoppe, "Romanik als Antike und die baulichen Folgen" 89-131. 
interested artistic and learned circles during the late fifteenth and early sixteenth centuries in Germany.

Thereby, I will examine three very diverse fields which are nonetheless connected by striking personal and geographical points of contact: firstly, fifteenth-century learned interpretations of Romanesque edifices and joint narrative constructions of an ancient and classical past shall be identified and put into the context of current intellectual life. Here, the collective label of humanism and its contemporaneous intellectual background will presumably help us understand more fully the above-mentioned built examples in terms of art historical and style analysis.

Secondly, references in the fictional primeval architecture contained in the works of contemporaneous North Alpine painters will be examined for traces of specific case studies and of an awareness of Romanesque buildings.

Finally, a new boom happening in the engagement with and recontextualization of spolia of Romanesque architecture will be discussed.

\section{Humanist Anachronistic Dating of Romanesque Buildings}

During the fifteenth century a fundamental new interest in the preserved remains of ancient material culture emerged, as is attested by a rich body of scholarly literature on Renaissance culture. Scholars have so far mainly examined this topic for the fifteenth century in connection with investigations related to the early Italian Renaissance or to the early history of archaeology. ${ }^{37}$ It was not only objects from classical Roman antiquity that were the targets of investigations and narrative reconstructions of the period, but also objects from later periods, the style of which resembled the older remains and could establish a link to previous historical eras. ${ }^{38}$

Quite well known are, for example, Italian humanist theories that classified the twelfth-century, centrally planned building of the Baptistery of San Giovanni in Florence as an ancient Roman Temple of Mars. ${ }^{39}$ By ascribing

37 Günther H., Das Studium der antiken Architektur in den Zeichnungen der Hochrenaissance (Tübingen: 1988); Schnapp A., La conquête du passé. Aux origines de l'archéologie (Paris: 1993).

38 Birnbaum V., Románská renesance koncem středověku (Prague: 1924), with a very different interpretation than presented in this study concerning the role of humanism.

39 Straehle G., Die Marstempelthese. Dante, Villani, Boccaccio, Vasari, Borghini. Die Geschichte vom Ursprung der Florentiner Taufkirche in der Literatur des 13. bis 20. Jahrhunderts (Munich: 2001). Further literature on the general topic: Gombrich E., "From the Revival of Letters to the Reform of the Arts: Niccolò Niccoli and Filippo Brunelleschi", in 
such an early date and by reinterpreting Romanesque architecture, the local fourteenth-century politician and chronicler Giovanni Villani (ca. 1280-1348) wished to present Florence - beyond a purely theoretical-historical interest as a legitimate heir of past Roman greatness. Important humanist scholars, such as Leonardo Bruni (ca. 1369-1444) and Angelo Poliziano (1454-1494), followed suit. It would not be until the seventeenth century, i.e. well beyond the development of a detailed and realistic knowledge of Roman architecture, that the fictitious Temple of Mars and the consequently mistaken perception of Romanesque architectural style as classical were increasingly challenged.

Around 1490, Venice intellectuals regarded the type of the Byzantine crossin-square church, popular since the tenth century, and local representatives, such as San Giacomo di Rialto (consecrated 1177), as the transmission of ancient temple architecture. Even though Vitruvius and other classical authors had described their architectural shapes, no appropriate image tradition existed to explain their forms. Hubertus Günther has explained the contemporary historiographical and artistic consequences:

As in the cases of the Byzantine tradition in Venice as well as the socalled proto-renaissance in Florence, a local pre-Gothic tradition was able to influence even in other regions the ideas of antiquity and provided a guideline for the renewal of antiquity. The integration of local pre-Gothic architectural traditions, as observed in the case of the cross-in-square church, was something completely normal during the Renaissance. ${ }^{40}$

The Romanesque church of San Giacomo di Rialto in Venice was actually still dated to the year AD 421 by sixteenth-century Italian authors. ${ }^{41}$ The first local testimonials of a corresponding early dating of the existing building go back as far as the $1420{ }^{42}$

Fraser D. - Hibbard H. - Lewine M.J. (eds.), Essays in the History of Art Presented to Rudolf Wittkower (London: 1969) 71-82; Ackerman J.S., "The Certosa of Pavia and the Renaissance in Milan", Marsyas 5 (1950) 23-37; Tietze H., "Romanische Kunst und Renaissance", Vorträge der Bibliothek Warburg 6 (1926/1927) 43-57; Nagel A. - Wood Chr. S., Anachronic Renaissance (New York: 2010). Wood Chr. S., "The Credulity Problem", in Miller P.N. et al. (eds.), Antiquarianism and Intellectual Life in Europe and China, 1500-180o (Ann Arbor: 2012) 149-179.

Günther H., "Die Vorstellungen vom griechischen Tempel und der Beginn der Renaissance in der venezianischen Architektur", in Naredi-Rainer P. von (ed.), Imitatio. Von der Produktivität künstlerischer Anspielungen und Mißverständnisse (Berlin: 2001) 104-143, here 138.

41 Günther, "Vorstellungen" 112.

42 Günther, "Vorstellungen" 114. 
Less well known is the fact that such early humanist attempts at dating and interpreting local or regional Romanesque architecture also started to leave their traces north of the Alps during the fifteenth century. Therefore, here we also find the first references to specific Romanesque buildings, the formal difference of which attracted the contemporaneous northern Alpine learned interest.

In Augsburg, the young Benedictine monk Sigismund Meisterlin (ca. 1435after 1497) had been commissioned by local elites to study the history of the city. In 1456, his research led to a new narrative that reconstructed the city's ancient history as being far older than the previously accepted Roman origins. Meisterlin was not only well connected to a local circle of early humanist clergy and lay-people, he also had excellent contacts with Italian humanists and their assistants. For example, the teacher of the Medici household and collector of classical manuscripts Enoch of Ascoli (1400-ca. 1457) had visited him in Augsburg on his return journey to Italy in $\mathbf{1 4 5 5}$. It is likely that he reported details about the rediscovered manuscript of Tacitus' Germania, which he had just acquired in Germany. ${ }^{43}$

In 1457, a special edition of Meisterlin's Augsburg Chronicle came out, furbished with remarkable illustrations that, through a range of diverse details, visualized the material culture and building history from the time of the city's foundation by the ancient Germanic tribe of the Vindelici, long before the arrival of the Romans. ${ }^{44}$ Among these illustrations is a visual reconstruction of the simple first lodgings in caves and in huts made of wattled branches, as well as of the first half-timbered buildings in the city ( $\mathrm{HB} \mathrm{v}, 5^{2}$, fol. $\left.14 \mathrm{v}\right)$. At the time, scholars in Augsburg engaged in innovative ways and in accordance with

43 Mertens D., "Die Instrumentalisierung der Germania des Tacitus durch die deutschen Humanisten”, in Beck H. (ed.), Zur Geschichte der Gleichung germanisch - deutsch. Sprache und Namen, Geschichte und Institutionen (Berlin - New York: 2004) 37-101, in particular 39 and 59-61.

44 Meisterlin Sigismund, Augsburger Chronik (1457); repository: Stuttgart, Landesbibliothek, Cod. HB v 52. Cf. Ott N.H., "Von der Handschrift zum Druck und retour. Sigismund Meisterlins Chronik der Stadt Augsburg in der Handschriften - und Druck-Illustration”, in Paas J.R. (ed.), Augsburg, die Bilderfabrik Europas. Essays zur Augsburger Druckgraphik der frühen Neuzeit (Augsburg: 2001) 21-29, here 22 and note 12; Saurma-Jeltsch L.E. - Frese T. (eds.), Zwischen Mimesis und Vision. Zur städtischen Ikonographie am Beispiel Augsburgs, Kunstgeschichte 87 (Berlin: 2010); Ott N.H., "Zum Ausstattungsanspruch illustrierter Städtechroniken. Sigismund Meisterlin und die Schweizer Chronistik als Beispiele”, in Füssel S. (ed.), Poesis et pictura. Studien zum Verhältnis von Text und Bild in Handschriften und alten Drucken, Festschrift für Dieter Wuttke zum 6o. Geburtstag (Baden-Baden: 1989) 77-106. 
current humanist patterns of interpretation with the material culture of local antiquity.

In 1478 , Meisterlin moved to a place near Nuremberg and started to concern himself with the alleged ancient foundation of the Franconian imperial city. ${ }^{45}$ There, he once more made contact with a circle of humanists, members of which included the well-known Nuremberg patricians Hermann Schedel (1410-1485) and Hartmann Schedel (1440-1514), as well as the entrepreneur and collector Sebald Schreyer (1446-1520).

In his Nieronbergensis Cronica, completed in 1488, Meisterlin not only dated the foundation of Nuremberg to the year 12 BC by using the context of the military campaigns of Drusus the Elder and Tiberius, but he also invoked the Margarethenturm (Margaret's Tower) of the Nuremberg Kaiserburg and the connected Romanesque court chapel as material proof of the great antiquity of the city. In accordance with this interpretation, Tiberius commissioned the building of 'ain alten starcken turen auff den velsen seczen zu ainer wart' ('an old strong tower set onto the castle hill as a watch tower'). In reality, the still existing tower was built in the period around 1200 and had been decorated with Romanesque structural elements and architectural sculpture. Meisterlin took the court chapel, neighbouring and coeval to the tower [cf. Fig. 19.4 bottom], for a pagan temple originally dedicated to Diana, and he even interpreted an image of the Madonna in this light. This kind of recontextualization and historiographical activation of prominent Romanesque architecture in Nuremberg was taken up and elaborated by other important humanists. In 1502, Conrad Celtis wrote about the building, albeit with some reservations:

Collis delubra tria et ornata habet, [...], tertium in imperiali arce angustis, quo Caesar rei divinae et sacrificiis ceremoniisque adsistit. Ferunt vulgo illud quosdam Dianae fuisse phanum eiusque rei argumentum adducunt idolon veteresque quasdam et incogniti simulacra imagines, quod ego $[\ldots]$ non quidem affirmaverim.

On the castle hill, there are three beautiful chapels [...]. The third, rather narrow one is located inside the castle. In it, the emperor attends the

45 Kießling R., "Wer etwas sucht, der sucht es offt an viel steten, da es nit ist'. Stadtgründungslegenden schwäbischer Reichsstädte im Spätmittelalter", in Dotterweich V. (ed.), Mythen und Legenden in der Geschichte (Munich: 2004) 47-75, here 68-72; Stemmermann P.H., Die Anfänge der deutschen Vorgeschichtsforschung. Deutschlands Bodenaltertümer in der Anschauung des 16. u. 17. Jahrhundert (Leipzig: 1934) 14; cf. Joachimsen P., Die humanistische Geschichtsschreibung in Deutschland, vol. 1: Die Anfänge: Sigismund Meisterlin (Bonn: 1895) 181. 
services and the mass. The people say that it used to be a temple dedicated to Diana, and they offer as a proof an idol as well as several old images that can no longer be identified. I cannot quite confirm this to be true $[\ldots] \cdot{ }^{46}$

This first reference probably served as the basis for a later handwritten German chronicle composed soon after 1525:

dieweil [Drusus] da lag pauet er ein thurn auff dem perg, gleich als zu einer wach unnd auff sehenns unnd das ist der thurn, so noch auf heutigen tag uff der vesten statt, an Sannct Margarethe Kirchen, wie man dann noch allte possenn unnd haidnische pild daran sicht, deren ettliche im Jar 1520 da man die Kirchen unnd das schloß geweychet unnd verneuert hatt, sindt herab geworfen worden.

While [Drusus] campaigned there, he built a tower on the hill, as a watch tower and lookout, and that is the tower that to this day stands on the castle at the church of St. Margaret. Accordingly, some old bizarre and pagan images can still be seen, several of which were thrown down in the year 1520 , when the chapel and the castle were newly consecrated and renovated. ${ }^{47}$

The notion of the antique origins of the Romanesque Margaret's Tower and of the Nuremberg court chapel persisted so tenaciously over the centuries that in 1739 an illustration with the eastern view of the chapel was still included in the Nürnbergische Altertümer by Carl of Wölckern [Fig. 19.12]. The caption ran:

46 See Schauerte T., "Antikenrezeption, Archäologie und Numismatik. Humanistische Bildthemen", in Schauerte T. with the assistance of Münch B. (eds.), Albrecht Dürer - das große Glückcelti. Kunst im Zeichen des geistigen Aufbruchs, exh. cat., Kulturgeschichtliches Museum Osnabrück (Bramsche: 2003) 101-107, here 104; Celtis, Konrad, 'Norimberga'. Ein Büchlein über Ursprung Lage Einrichtung und Gesittung Nürnbergs vollendet um das Jahr 1500 gedruckt vorgelegt 1502, ed. and trans. G. Fink (Nuremberg: 2000) 39-40. English translation here A. Gáldy.

47 Vienna, Österreichische Nationalbibliothek (ÖNB), Cod. 12640, fol. $24 \mathrm{v}$; translation based on Ott M., "Römische Inschriften und die humanistische Erschließung der antiken Landschaft. Bayern und Schwaben. Die Dokumentation antiker Inschriften im frühen 16. Jahrhundert. Konrad Peutinger und Johannes Aventinus", in Brendle F. - Mertens D. Schindling A. - Ziegler W. (eds.), Deutsche Landesgeschichtsschreibung im Zeichen des Humanismus (Stuttgart: 2001) 213-226, here 265 . 


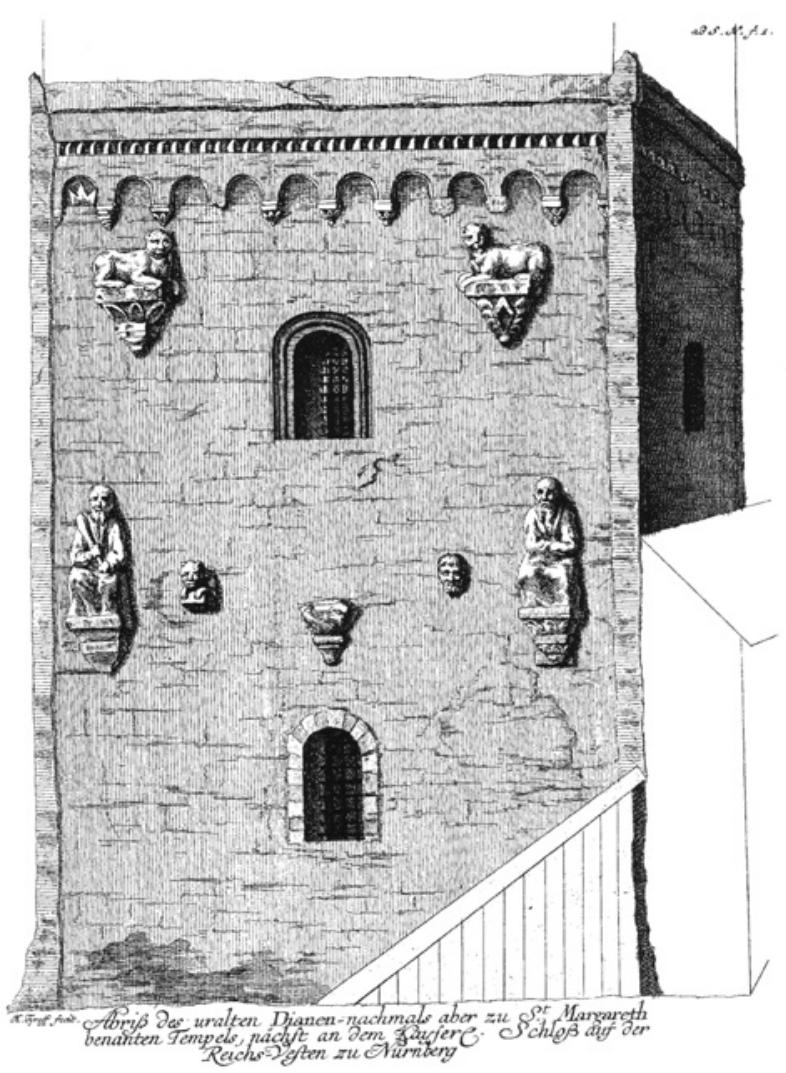

FIGURE 19.12 Margaret's Tower of the Kaiserburg in Nuremberg, depicted as a Roman temple. Engraving, taken from: Lazarus Carl von Wölckern, Singularia Norimbergensia (Nuremberg: 1739). Fig. after page 244 IMAGE (C) PUBLIC DOMAIN

'elevation of the ancient Diana temple - later dedicated to St. Margaret next to the imperial castle on the imperial fortress at Nuremberg. 48

48 'Abriß des uralten Dianen - nachmals aber zu St. Margareth benannten Tempels nächst an dem Keyserl. Schloß auf der Reichs-Vesten zu Nürnburg', see Wölckern, Lazarus Carl von, Singularia Norimbergensia oder aus denen Geist - und Weltlichen Rechten und Geschichten sowohl als Glaubwürdigen Zeugnussen besonders erläuterte Nürnbergische Alterthümer und andere vornemlich merckwürdige Begebenheiten auch insonderheit zu Nürnberg gepflogenen Reichs-Handlungen und Zusammenkünffen (Nuremberg, J.A. Endter: 1739), fig. after 244; cf. Schauerte, "Antikenrezeption” 105. 
Almost contemporaneously, in Ulm, which was located near Augsburg and engaged in an intensive exchange with German early humanists, Romanesque architectural remains were also dated to an ancient past. Around 1488, the Dominican Felix Fabri (ca. 1438/1439-1502), resident in Ulm from 1468, started to investigate the foundation of the monastery of Wiblingen outside the city gates in the eleventh century for his chronicle of the city of Ulm, the Tractatus de civitate Ulmensi. To underpin his dating of the age of the precedent church there, he argued that:

When the holy city of Jerusalem had been liberated by our troops and the counts mentioned above had returned sane and safe, they were told by the architects that the building would not be able to stay on the mentioned hill and that no large building would be able to stand there because of the sandy quality of the hill.

Therefore, they held a council and placed the foundations of the monastery on the spot where it is still today by the grace of God. Not long afterwards, the hill on which they had originally started to build fell apart, and part of the previous church, the sculptures of which seem to attest to a construction date of $\mathrm{AD} 444$, suddenly collapsed, together with part of the churchyard. When excavations were conducted afterwards, human remains were found that slid down together with the earth. ${ }^{49}$

In the chronicle's Latin original version, the crucial part of the passage reads 'pars antiquae ecclesiae (quae constructa fuit anno domini 444 sicut sculptura docere videtur). ${ }^{50}$ Remarkable is the use of the verb 'docere' and the active role thus attributed to the 'sculptura' in the teaching of historical knowledge. ${ }^{51}$ Sigismund Meisterlin's and Felix Fabri's references to architectural remains of

49 An edition of the chronicle was published by Veesenmeyer G., Fratris Felicis Fabri Tractatus de civitate Ulmensi, de eius origine, ordine, regimine, de civibus eius et statu (Tübingen: 1889). The quotation used here is based on the German translation by Haßler K.D., Bruder Felix Fabris Abhandlung von der Stadt Ulm nach der Ausgabe des litterarischen Vereins in Stuttgart verdeutscht (Ulm: 1909) 117-118, cf. Fabri, Felix, Tractatus de civitate Ulmensi, trans. F. Reichert (Eggingen: 2012). Fabri's Ulm chronicle has remained largely understudied; a recent work on subject is Kießling, "Wer etwas sucht" here esp. 59-64; also cf. Graf K., “Ulmer Annalen' und 'Ulmer Chronik”, in Stammler W. - Langosch K. - Ruh K. (eds.), Die deutsche Literatur des Mittelalters, Verfasserlexikon, vol. 11, 2nd ed., instalment 5 (Berlin - New York: 2004) 1580-1583.

50 Veesenmeyer, Fratris Felicis 175 .

$5^{1}$ I wish to thank Ute Verstegen (Erlangen) for her help in sharpening the focus of this interpretation. 
a pre-Gothic style belong to the early testimonies transmitted in writing from areas north of the Alps, in which phenomenological observations had been used by humanists in an attempt to date ancient architecture that we would rather consider to be part of the Romanesque art historical period. ${ }^{52}$

Recently, Christopher Wood reconstructed a further impact-generating encounter of humanist scholarship with North Alpine Romanesque architectural sculpture. ${ }^{53}$ Conrad Celtis reports in his programmatic ideal description of Nuremberg, completed in 1495 and published in 1502, six figures, seemingly sculptural, of Germanic Druids, which he had seen in a monastery located in the Fichtelgebirge north of Ratisbon. ${ }^{54}$ Wood persuasively locates these alleged testimonies of Germanic and pre-Roman proto-history in Germany on a figured portal, lost today, of the twelfth-century monastery of Speinshart, which the Ingolstadt professor of poetry and rhetoric Celtis visited with his friend, the Ratisbon humanist and astronomer Johannes Tolhopf (1429-1503), in the early 1490 .

Given the subsequent loss of the artefacts, it is impossible to make firm statements about the appearance, style, and actual date of the presumed Romanesque portal in the Fichtelgebirge. Celtis' student Johannes Aventin (1477-1534), however, disseminated this interpretation well into the sixteenth century, and Hartmann Schedel included it in his notes.

Wood implies that the two humanists, ca. 1490, must have been aware of the real construction date of the portal in the twelfth or thirteenth century. At the same time, he nonetheless asserts that the dating techniques of historical buildings based on style were still limited, even during the late Middle Ages, and that they rested above all on typological characteristics. ${ }^{55}$

The examples gathered together in the present case study may, however, be rated as an evidence that the techniques of stylistic differentiation of historical buildings had become more sophisticated in highly educated circles during the

$5^{2}$ Lukas Clemens' investigations were able to show that this interest north of the Alps was a new development after the thirteenth and fourteenth centuries had witnessed a continuous decrease of engagement with the oldest architectural remains, cf. Clemens L., Tempore Romanorum constructa. Zur Nutzung und Wahrnehmung antiker Überreste nördlich der Alpen während des Mittelalters (Stuttgart: 2003).

53 Wood C.S., Forgery, Replica, Fiction. Temporalities of German Renaissance Art (Chicago: 2008) $1-13$.

54 Celtis, Conrad, De origine, situ, moribus et institutis Norimbergae libellus = part of Quattuor libri Amorum secundum quattuor latera Germaniae (Nuremberg, Sebald Schreyer Vincent Longinus: 1502).

Wood, Forgery 43-50. 
fifteenth century. In this case, the development in Central Europe corresponds, at least in its general trend, to the much better explored development in Italy ${ }^{56}$

Wood thus takes up Celtis' interpretation of the Romanesque figured portal and other observations of the contemporaneous dealings with historical artefacts in Germany. In addition, he discusses the theory of a contemporaneous dualism, or rather a radical change, in the historical thinking about artefacts. I agree with him when he states that during the Renaissance period diverse schools of thought competed with one another and that it is impossible to apply modern theories about the unrepeatability of the creative process and about the aim of absolute dates. Nonetheless, it will remain to be seen whether precisely the new awareness for the stylistic traits of older art and architecture as described in the present article under a range of diverse perspectives led to a correct understanding.

The diverse functions of contemporaneous attributions and dates will have to be reconstructed in detail. In any case, the search for textual as well as for material testimonies of a Roman and Germanic proto-history belonged to the typical practices of early humanists in Germany during the final third of the fifteenth century. ${ }^{57}$

An additional, somewhat younger example of this type of interpretation of Romanesque architecture also comes from the sphere of southern German humanism. The humanist and Lutheran theologian Andreas Althamer (ca. 1500ca. 1539), born in Brenz, near Ulm, in the second edition (1536) of his Latin commentary on Tacitus, presented the church of his native village as a Roman edifice:

Fuisse enim Romanos in iis locis, primum arguit lapis intrinsecus muro insertus, hac inscriptione [...], deinde numismatica [...], et quod ipsius templi structura mirandam quondam vetustatem referat. Nam foris per muri gyrum sunt ad ducentos ferme lapides excisi variarum imaginum miri operis et aethnicae antiquitatis indices. Sunt regum, reginarum, virorum, mulierum, centaurorum effigies. Avium varia genera, aquilae, pellicani, grues, ciconiae, cygni, struthiones, auritae propendulis et longe patentibus auribus, basilisci, galli, gallinae, et aliae mihi prosus ignotae. Animalia leones, thauri, cervi, canes venatici, apri, pardi, pantherae, porci,

$5^{6}$ Cf. Strätz H.W., "Notizen zu 'Stil' und Recht”, in Gumbrecht H.U.(ed.), Stil. Geschichten und Funktionen eines kulturwissenschaftlichen Diskurselements (Frankfurt a.M.: 1986) 53-67. Pfisterer U., Donatello und die Entdeckung der Stile. 1430-1445 (Munich: 2002).

57 Fundamental on the issue: Ott M., Die Entdeckung des Altertums der Umgang mit der römischen Vergangenheit Süddeutschlands im 16. Jahrhundert (Kallmünz: 2002). 
simiae, lepores, hirci, feles, asini. Monstra marina, syrenes, pisces, cancri, araneae, testudines. Praeterea labyrinthi, rosae, lilia, flores, folia et alia multa. Si orthodoxa fides tum fuisset huic populo praedicta, haud dubie aliquid Christiani operis de dominica passione aut sacris historiis incidissent: nunc cum nihil harum rerum cernatur, coniicio ante plantatam iis locis fidem, non Germanos, sed Romanos id aedificii struxisse: nam et populares mei ab paganis (ita ethnicos apellant) extructum praedicant.

There were Romans in these locations; on the one hand this is attested by a stone with this inscription [...] set into this wall, on the other hand by coins $[. .$.$] as well as by the fact that the building of this temple shows its$ amazing antiquity. For outside, on the apse, there are nearly 200 stones sculpted into various images that betray particular workmanship and an origin in the pagan antiquity. These include images of kings, queens, men, women and centaurs. There are diverse kinds of birds - eagles, pelicans, cranes, storks, ostriches, creatures with protruding and long ears, basilisks, roosters, hens and others that are totally unknown to me - of animals such as lions, bulls, stags, hunting dogs, wild boars, panthers, pigs, monkeys, hares, bucks, cats and donkeys, and of sea monsters: sirens, fish, crabs, spiders and turtles; finally, of labyrinths, roses, lilies, flowers, leaves and many other things. If the true faith had been preached among the people at the time, would they not have (then) sculpted other Christian works of the Passion of our Lord or holy legends? Since it is impossible to find any trace of these things, I conclude that before the planting of the faith at this place, it was not Germans but Romans who erected this building: for my compatriots say as well that they were built by 'pagans', which is their name for heathen people. ${ }^{58}$

In contrast to the church in Wiblingen, the Romanesque church in Brenz is preserved to this day; modern art history dates it to the period of ca. $1240 .{ }^{59}$ The truly Roman stone with the inscription that Altheimer mentions still survives as a spolia inserted into the walls of the apse, as well as the rich figurative

58 Althamer, Andreas, Commentaria Germaniae in P. Cornelii Taciti Equitis Romani libellum de situ, moribus et populis Germanorum (Nuremberg: Petreius, 1536) (this second edition, commented by Althamer, had been considerably extended as far as its commentary was concerned in comparison to the 1529 one), cited according to Körte W., Die Wiederaufnahme romanischer Bauformen in der niederländischen und deutschen Malerei des 15. und 16. Jahrhunderts (Wolfenbüttel: 1930) 86.

59 Cichy B., Die Kirche von Brenz (Heidenheim: 1966); Messerschmidt W., Gallus-Kirche Brenz (Brenz: 1975). 
ornamentation of the Romanesque Lombard band, which Altheimer lists in such detail and attempts to interpret.

\section{Fiction and Reinterpretation of Romanesque Architectural Motifs in Fifteenth-Century North Alpine Visual Art}

Parallel to the early humanist attempts to date and interpret local Romanesque buildings as material witnesses of ancient German culture and history, a further debate about the stylistic traits of Romanesque architecture developed north of the Alps. It is not yet clearly established how its origin was connected to the regional as well as to the European humanist debate. The new interest expressed by some representatives of the art of painting fed its development, which may first be observed in the Netherlands and was increasingly adopted in Germany from the 145 os onwards. ${ }^{60}$

The Ghent Altarpiece, completed in 1432 by the Flemish painter Jan van Eyck (ca. 1390-1441), displays in its weekday scene (with the outer wings closed) an Annunciation that is placed inside a boxlike interior. On the back wall, three mullioned windows divided by a central column are inserted. In two cases, beyond the windows, in a second wall, are windows with Gothic tracery. In the three anterior mullioned windows, windows of a Romanesque style are evoked visually in minute detail without being true depictions of particular originals.

Never before had Gothic painting differentiated visually so clearly between two architectural styles, and never had the by then outdated Romanesque architectural ornamentation been observed so carefully by a painter. The Romanesque two-light windows have mullions in the guise of double columns set obliquely to the wall, with shafts made of black marble and with sculpted bases and capitals. The bases are reminiscent of upside-down capitals, with a crown of leaves based on French twelfth-century crocketed capitals. The capitals consist of a crown of leaves placed above the characteristic head of a cubiform capital as it had been developed in Central European architecture shortly after the year 1000. Prominent examples of this kind of cubiform capital exist in St Michael in Hildesheim (ca. 1010) or at Speyer Cathedral (ca. 1025). Nonetheless, there are no examples of a similar shape of composite capitals

6o Körte, Wiederaufnahme; Panofsky E., Die altniederländische Malerei. Ihr Ursprung und Wesen, eds. J. Sander and S. Kemperdick, 2 vols. (Cologne: 2001), here in particular vol. 1, 143-144; Frodl-Kraft E., "Der Tempel von Jerusalem in der 'Vermählung Mariae' des Meisters von Flémalle. Archäologische Realien und ideale Bildwirklichkeit”, in Crosby McKnight S. et al. (eds.), Etudes d'art médiéval offertes à Louis Grodecki (Paris: 1981) 293-316. 
as depicted in the paintings known in Europe. Here it can only be mentioned briefly that the closest known parallels to the composite capital design and to the double columns shown on the Ghent Altarpiece may be found in the mid-eleventh-century column grid inside the church of the Holy Sepulchre in Jerusalem. ${ }^{61}$

While a possible model for the Ghent Altarpiece in Jerusalem probably has to remain hypothetical, more precise models and perhaps also de facto objects of study may be tied to visual evocations of Romanesque architectural motifs in the pictorial work of Jan van Eyck. In the Annunciation (today Washington, DC, formerly St Petersburg), commissioned ca. 1436 as a donation by Duke Philip the Good for the Charterhouse of Champmol near Dijon, the pictorial space is determined by the corner situation of a basilica-type edifice with ambulatories that run on two sides halfway up along the walls. ${ }^{62}$ Such details as the monolithic columns below the clerestory wall, the multilayered wall structure, and the arched windows without tracery on the upper storey, could then be observed in the older Romanesque churches of the RhineMeuse region.

Of particular significance is the shape of the triforium-type gallery in the painted architecture of the Annunciation, in which three or five elongated colonnettes per bay carry one straight lintel. A similar architectural situation is still visible in the triforium of the transepts of Tournai Cathedral that were begun ca. 1170 and vaulted in 1198; in this case, we are dealing with with a motif

$61 \quad H o p p e$ S., "Die Antike des Jan van Eyck. Architektonische Fiktion und Empirie im Umkreis des burgundischen Hofs um 1435", in Boschung D. - Wittekind S. (eds.), Persistenz und Rezeption. Weiterverwendung Wiederverwendung und Neuinterpretation antiker Werke im Mittelalter (Wiesbaden: 2008) 351-394.

62 On the date and context of the donation see Suckale R., "Zum Körper - und Wirklichkeitsverständnis der frühen niederländischen Maler", in Schreiner K. (ed.), Frömmigkeit im Mittelalter: politisch-soziale Kontexte, visuelle Praxis, körperliche Ausdrucksformen (Munich: 2002) 271-297, here 275; Purtle C.J., "Van Eyck's Washington Annunciation: Narrative Time and Metaphoric Tradition", The Art Bulletin 81 (1999) 117-125; Gifford E.M., "Van Eyck's Washington Annunciation: Technical Evidence for Iconographic Development", The Art Bulletin 81 (1999) 108-116; Purtle C.J., The Marian Paintings of Jan van Eyck (Princeton: 1982); Purtle C.J., "Assessing the Evolution of Van Eyck's Iconography through Technical Study of the Washington Annunciation II: New Light on the Development of Van Eyck's Architectural Narrative", in Foister S. - Jones S. Cool D. (eds.), Investigating Jan van Eyck, exh. cat., The National Gallery London (London: 2000) 67-78; Gifford E.M., "Assessing the Evolution of Van Eyck's Iconography through Technical Study of the Washington Annunciation I", in Foister - Jones - Cool, Investigating Jan van Eyck 67-78; Harbison C., Jan Van Eyck: The Play of Realism (London: 1991); Lyman T.W., "Architectural Portraiture and Jan van Eyck's Washington Annunciation", Gesta 20 (1981) 263-271. 
that is very rare in northern Alpine architecture, and therefore all the more important for the painting with regard to its source of derivation. ${ }^{63}$ In Tournai Cathedral, the two-layered structure of the arcades as well as buttressing that spans more than one storey may be observed, the same as van Eyck had originally set out in the preliminary sketch of the pictorial architecture but had later overpainted. ${ }^{64}$

Even more conspicuous are the similarities between the imaginary wall structure in the Washington Annunciation and another church in Tournai, to which Robert Suckale has drawn attention. The twelfth-century church of St. Quentin has a triforium in the bays next to the crossing that is partially executed as a blind and the horizontal lintel of which is borne by five elongated colonnettes. ${ }^{65}$ Underneath this section of the wall, beyond the pillars of the crossing, columns carry an ogival arcade. The profile of these arches in the transepts shows the kind of step that is so typical of the lower storeys of van Eyck's architecture. Even one of the characteristics of the painted architecture - in which rounded arches are placed on top of ogival arches in an irritating contradiction of the architectural development of styles as seemingly reflected by building chronology - may be found in these bays of St Quentin. Considering the geographical vicinity between Jan van Eyck's workshop in Bruges during the 1430 and the famous cathedral city of Tournai, it seems plausible that the two churches mentioned above may have provided important details for Jan van Eyck's stylistic imagination without a specific building being copied in its spatial impression.

Almost contemporaneously with Jan van Eyck, Rogier van der Weyden (1399/1400-1464), who had recently moved to Brussels and become the court artist of the Burgundian dukes, began to study Romanesque architectural elements and to integrate them into his paintings. One work that may serve as an example is the so-called 'Lukas-Madonna' (Saint Luke Drawing the Virgin, today in Boston), which most scholars agree on dating to the years of ca. 1435/1440. 66

63 The reference to Tournai is already to be found in Panofsky E., Early Netherlandish Painting: Its Origins and Character (Cambridge, MA: 1953). The additional references to the architecture of the cathedrals at Sens and Canterbury included by Panofsky will not be examined here.

64 See the infrared reflectogram, Fig. 2 in Gifford, "Technical Study of the Washington Annunciation I" 59 .

65 Suckale, "Körper - und Wirklichkeitsverständnis" 275.

66 De Vos D., Rogier van der Weyden: The Complete Works (New York: 2000) cat. no. 8; Purtle C.J. (ed.), Rogier van der Weyden: St. Luke Drawing the Virgin: Selected Essays in Context (Turnhout: 1997); Kruse C., "Rogiers Replik. Ein gemalter Dialog über Ursprung und Medialität des Bildes", in Kruse C. - Thürlemann F. (eds.), Porträt - Landschaft Interieur. Jan van Eycks Rolin-Madonna im ästhetischen Kontext (Tübingen: 1999) 167-185; 
In this painting, Rogier referred very closely to a slightly older Madonna that had been done for the Burgundian chancellor Nicolas by his colleague Jan van Eyck, which also displays closely observed Romanesque architectural elements: the famous Madonna of Chancellor Rolin.

Rogier's reference included the new themes of an empirically substantiated pictorial architecture and of the landscape in the background. Here Rogier explained to the informed spectator that the imaginary architectural scenery was not a mere copy of pictorial elements existing in van Eyck's work, but that his new edition was based on an autonomous study of reality. For this purpose, he not only appropriately changed van Eyck's fictitious architecture, but presented it as the result of his own research on real Romanesque building details.

Rogier was not content to frame his painted opening in the background wall by van Eyck's marble columns. Their shafts looked grand, if stylistically unspecific, as did those used by Jan van Eyck in other historicizing architectural examples, such as for the Virgin and Child with Canon van der Paele and the Dresden Triptych, both created during the late $1430 \mathrm{~s}$.

Rogier's own column shafts constituted in 1435 a minor antiquarian revolution, since their torsion motif unmistakably repeats the typically elaborate forms of ornaments of real column shafts from the Romanesque period. In the older tradition of pictorial architecture in the Netherlandish artistic sphere, this torsion motif had remained unknown, and it seems certain that Rogier had only been able to gain access to it by means of personal empirical study of appropriate models from real Romanesque architectural works of different sizes.

Therefore, this architectural detail may be understood as the result of Rogier's innovative empirical studies as well as the contemplation of possibilities of production within a newly discovered historicizing architectural language. In addition, it also functions as evidence for the notion of an incomplete and ongoing process of the study of historical relicts. Finally, the apostle creating the drawing in the painting refers to the manual procedure of image creation.

We can only surmise where Rogier studied the Romanesque decorated and sculptured shaft forms. They often occurred during the Romanesque period on colonnaded portals, such as they appear on the northern and southern sides of Tournai Cathedral from the mid-twelfth century. After all, Tournai was Rogier's long-term place of work before his move to Brussels. The columns

Kemperdick S. - Sander J. (eds.), Der Meister von Flémalle und Rogier van der Weyden, exh. cat., Städel Museum and Gemäldegalerien der Staatlichen Museen zu Berlin (Ostfildern: 2008), cat. no. 48 (refers here to the copy in Bruges). 
with decorated shafts preserved there are the result of modern restoration; nonetheless, it is probable that they follow their models rather faithfully. Inside the nave of the Cathedral, similar, more torsioned column shafts may be seen, in this case in their original state of conservation. This is not to say that Rogier had used exactly these sculptured column shafts as models for his panel painting. Twelfth-century goldsmiths' works or other forms of microarchitecture which are stylistically related may equally be considered as models, even though today only a tiny fraction of these works is preserved.

In German-speaking regions, the interest in painted illusions of Romanesque architecture spread in particular from the $1450 \mathrm{~s} .{ }^{67} \mathrm{At}$ this point, German artists and their audiences engaged more intensively with many of the Netherlandish pictorial innovations. ${ }^{68}$ An active early protagonist of this reception of Netherlandish image culture was the Franconian painter Hans Pleydenwurff (ca. 1420-1472), who ca. 1455 (then still in Bamberg) had placed his scene of the Adoration of the Magi inside a palace of Romanesque architectural style on his Löwensteinsches Marienretabel (GNM Gm 132) [Fig. 19.13], following the model of Rogier van der Weyden's famous Columba altarpiece. ${ }^{69}$ To explain the new use of Romanesque forms as a stylistic indication of biblical antiquity, Pleydenwurff added to his pictorial invention appropriate antiquicizing inscriptions and image applications. The work commissioned by the Bamberg canon Count Georg of Löwenstein was a very famous painting in his time.

From this period there existed ever more numerous examples for a pictorial mise-en-scène of architecture, including Romanesque stylistic elements in drawn and painted works executed in Nuremberg. ${ }^{70}$ The same happened

67 Jan van Eyck's innovation towards the stylistic aspects of architecture was first adopted in the German lands by Stefan Lochner in Cologne. See Hoppe S., "Architekturstil und Zeitbewusstsein in der Malerei Stefan Lochners. Verwendung und Vorbilder", in Euskirchen C. - Kieser M. - Pfotenhauer A. (eds.), Hörsaal, Amt und Marktplatz. Forschung und Denkmalpflege im Rheinland, Festschrift für Udo Mainzer zum 6o. Geburtstag (Regensburg: 2005) 57-70.

68 For a general survey about the process of adoption of Netherlandish painting in fifteenth-century Germany, see Borchert T.H. (ed.), Van Eyck to Dürer: The Influence of Early Netherlandish Painting on European Art, 1430-1530 (London - New York: 2011).

69 Fundamental work on fifteenth-century Franconian painting: Suckale R., Die Erneuerung der Malkunst vor Dürer, 2 vols. (Petersberg: 2009), here vol. 2, cat. no. 25 Löwensteinsches Marienretabel. Cf. cat. no. 42 and 47 with more painted Romanesque details and vol. 1,

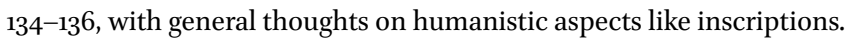

70 In Nuremberg, this idea was adopted, for example, by Michael Wolgemut (1434-1519) in the Nuremberg Chronicle 1493; Schedel, Hartmann - Wolgemut, Michael - Pleydenwurff, Wilhelm, Liber chronicarum (Nuremberg, Anton Koberger: 1493), i.e. Beheading of John the Baptist, fol. XCIIII; Pentecost, fol. CII; and Mohammed, fol. CLI; and later by his student Albrecht Dürer (Paumgartner-Altar, ca. 1503). 


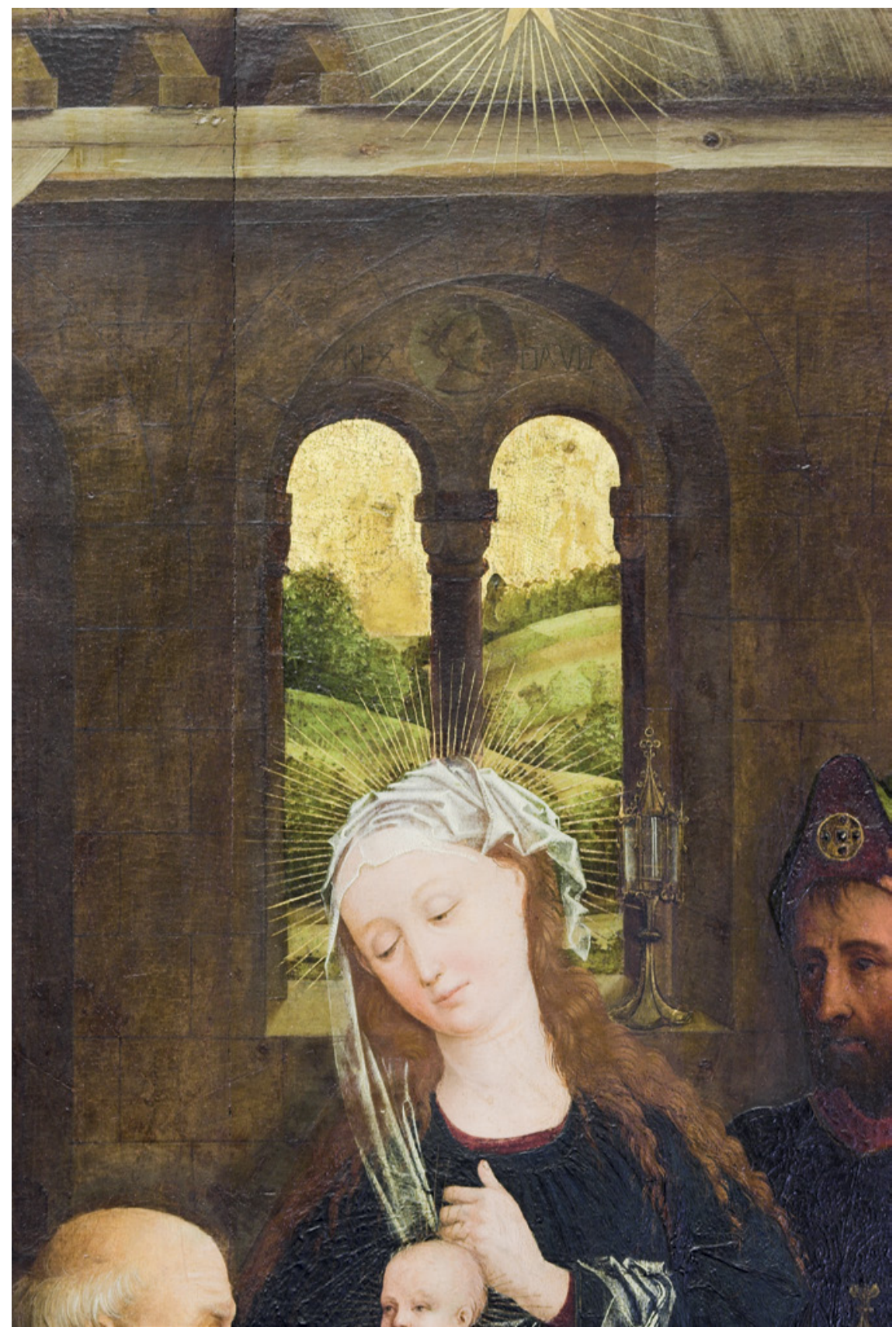

FIgURE 19.13 Hans Pleydenwurff, Adoration of the Magi with the palace of King David (detail); part of the Löwensteinsches Marienretabel (ca. 1455). Nuremberg, Germanisches National Museum

IMAGE (C) AUTHOR 
in neighbouring artistic centres, for example at the ducal court of George the Rich and Hedwig of Poland, at Landshut. ${ }^{71}$

It can be shown that in this period certain German humanists also acted as patrons of such new pictorial subjects. In 1457, an anonymous painter was commissioned to illustrate the chronicle of the city of Augsburg (now Stuttgart WLB), written by the above-mentioned Sigismund Meisterlin. Prompted by the innovative way in which the chronicle reported about the city's ancient protohistory, the artist purposefully used pictorial fictions of Romanesque buildings to visualize for an educated audience the pagan period of Augsburg before Christianization and the arrival of the Romans [Fig. 19.14]. ${ }^{72}$ Thus it was here that the pictorial practice starting with Jan van Eyck ca. 1435 and the early humanist debate directly met. The same may have happened in Nuremberg and Landshut only a little later, even though further research on this is needed.

In this context, an artistic project of a hybrid character was undertaken with great effort in the free imperial city of Ulm from the second half of the 146os. In 1468 the woodcarver and carpenter Jörg Syrlin the Elder (ca. 1425-1491) was commissioned to create the first part of the wooden choir stalls in the municipal parish church, the so-called Ulmer Münster (Ulm Minster), under construction since $1377 \cdot^{73}$ This three-part sedile was signed and put in place by Syrlin in the following year, while between 1469 and 1474 Syrlin and his workshop created the adjacent choir stalls for the Minster, which would become highly renowned in the older municipal historiography as well as in modern art history [Fig. 19.15]. ${ }^{74}$

In this work - sedile and stalls - occurs a surprising interrelated reference to pagan antiquity both in terms of content as well as in format and style, for

71 In Landshut, the court painter Sigmund Gleismüller, ascertainable from ca. 1473, used appropriate architectural forms based on Romanesque style, for example in the ca. 1485 altarpiece of Attel (Bavarian State Gallery at Burghausen Castle); see Statnik B., Sigmund Gleismüller. Hofkünstler der reichen Herzöge zu Landshut (Petersberg: 2009).

72 Meisterlin, Augsburger Chronik (Stuttgart, Württembergische Landesbibliothek, manuscript HB v 52, fol. 21 r; http://digital.wlb-stuttgart.de/purl/bsz330045024); cf. Delarue D.E., "Das Bild Augsburgs als Stadt. Repräsentation von Größe, Heiligkeit und Einigkeit in den Illustrationen zur Stadtchronik Sigismund Meisterlins", in Saurma-Jeltsch - Frese, Zwischen Mimesis und Vision 35-58, here 39.

73 Reinhardt B. - Roller S. (eds.), Michel Erhart und Jörg Syrlin d. Ä. Spätgotik in Ulm, exh. cat., Ulmer Museum (Stuttgart: 2002).

74 Vöge W., Jörg Syrlin der Ältere und seine Bildwerke. II: Stoffkreis und Gestaltung (Berlin: 1950); Deutsch W., "Der ehemalige Hochaltar und das Chorgestühl. Zur Syrlin - und zur Bildhauerfrage", in Specker H.E. - Wortmann R. (eds.), 6oo Jahre Ulmer Münster (Ulm: 1977) 242-322; Gropp D., Das Ulmer Chorgestühl und Jörg Syrlin der Ältere. Untersuchungen zu Architektur und Bildwerk (Berlin: 1999). 


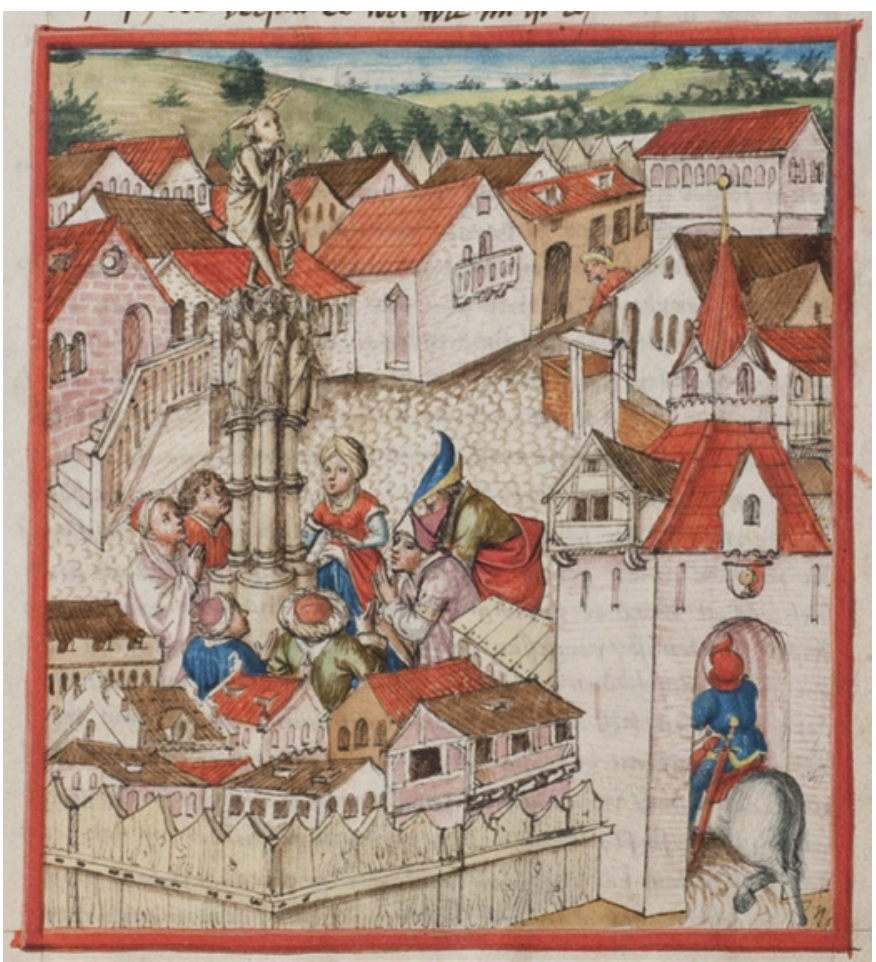

FIGURE 19.14 Sigismund Meisterlin, Augsburger Chronik, Veneration of the pagan goddess Cisa, Stuttgart version from 1457. Stuttgart, Württembergische Landesbibliothek, manuscript $\mathrm{HB} \mathrm{V}_{52}$, fol. $21 \mathrm{r}$

IMAGE (C) WLB IN THE PUBLIC DOMAIN

which there was no precise antecedent in the northern Alpine artistic sphere at the time. The new furnishings of the Ulm Minster display not only the usual people from the Old and New Testaments, as one would expect in such a place, but also an innovative and very prominent presentation of pagan Wise Women and Learned Men of Greek and Roman, i.e. pre-Christian, antiquity. In their artful and innovative multiple viewpoints, these effigies of ancient male and female intellectuals, such as Ptolemy, Terence, Virgil, Cicero, Quintilian, sibyls, and others, are reminiscent of ancient busts and function as tentative attempts to connect with ancient stylistic principles. A famous Italian example of a cycle of sibyls was the one painted for the humanist Giordano Orsini in Rome ca. 1425; a prominent later cycle was executed for Sigismondo Malatesta in Rimini ca. $1455 .{ }^{75}$ Today most of the Ulm busts are considered early masterworks of 


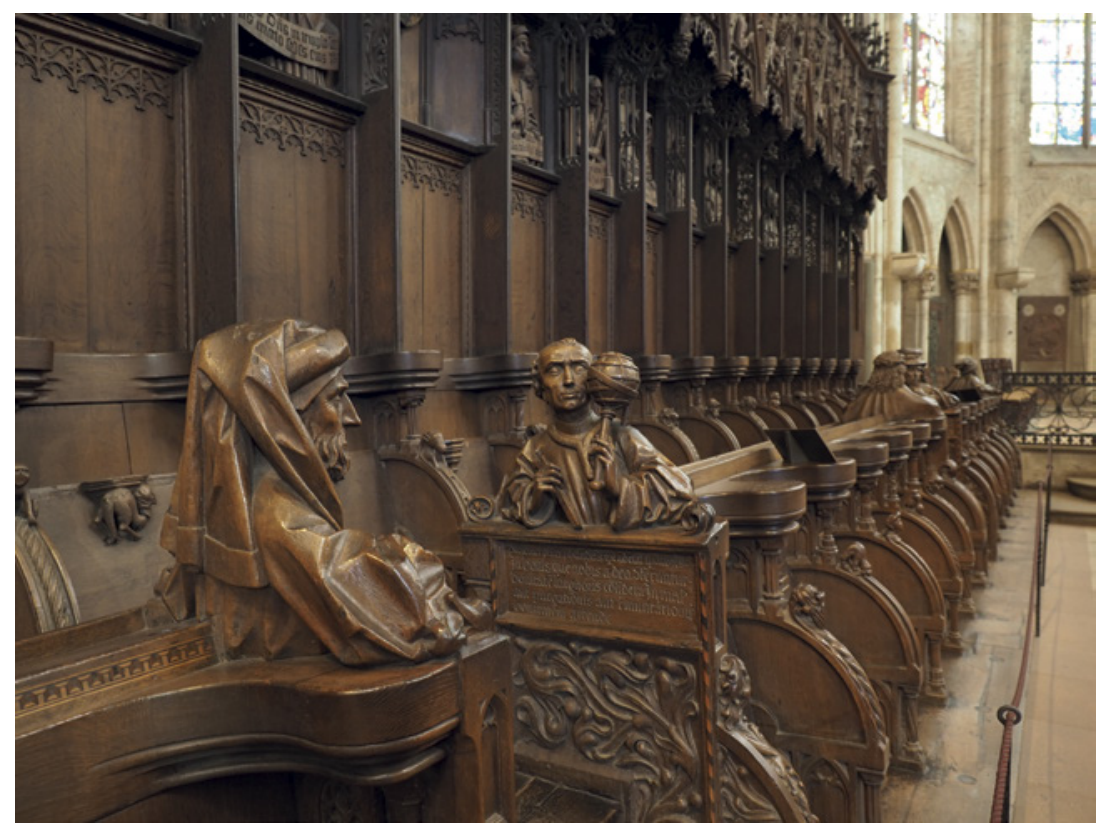

FIGURE 19.15 Jörg Syrlin the Elder and Michel Erhart, choir stalls of Ulm Minster with the busts of Seneca and Ptolemy (1469-1474)

IMAGE (C) AUTHOR

the then still rather young woodcarver Michel Erhart (ca. 1440/1445-post 1522), created under the supervision of Jörg Syrlin the Elder.

At first glance the microarchitecture of the Ulm stalls, ${ }^{76}$ carrying and framing the images, acts as an implementation of then modern Gothic architectural motifs in the so-called schöner Stil (international Gothic). ${ }^{77}$ Closer formal analysis, however, brings to light that Syrlin the Elder at the same time also used motifs of pre-Gothic, i.e. here Romanesque, architecture [Fig. 19.16]. This becomes particularly clear through the stylistic comparison with the slightly older stalls (1467-1470) of Constance Minster that catered for the imperial city and that in certain parts might actually be regarded as a model for Ulm. In Constance one can see, in the lower parts of the seating stalls as well as further above, artful yet contemporary Gothic architectural forms, but in Ulm there is

76 On the topic of microarchitecture for this period, see in particular: Kratzke C. - Kratzke U.A. (eds.), Mikroarchitektur im Mittelalter. Ein gattungsübergreifendes Phänomen zwischen Realität und Imagination (Leipzig: 2008); Kavaler, Renaissance Gothic; Timmermann A., Real Presence: Sacrament Houses and the Body of Christ. c. 1270-1600 (Turnhout: 2009).

77 See Schurr M.C., "Der 'Schöne Stil' in der Architektur um 1400", in Braun K.H. (ed.), Das Konstanzer Konzil 1414-1418. Weltereignis des Mittelalters, vol. II (Stuttgart: 2013) 171-174. 

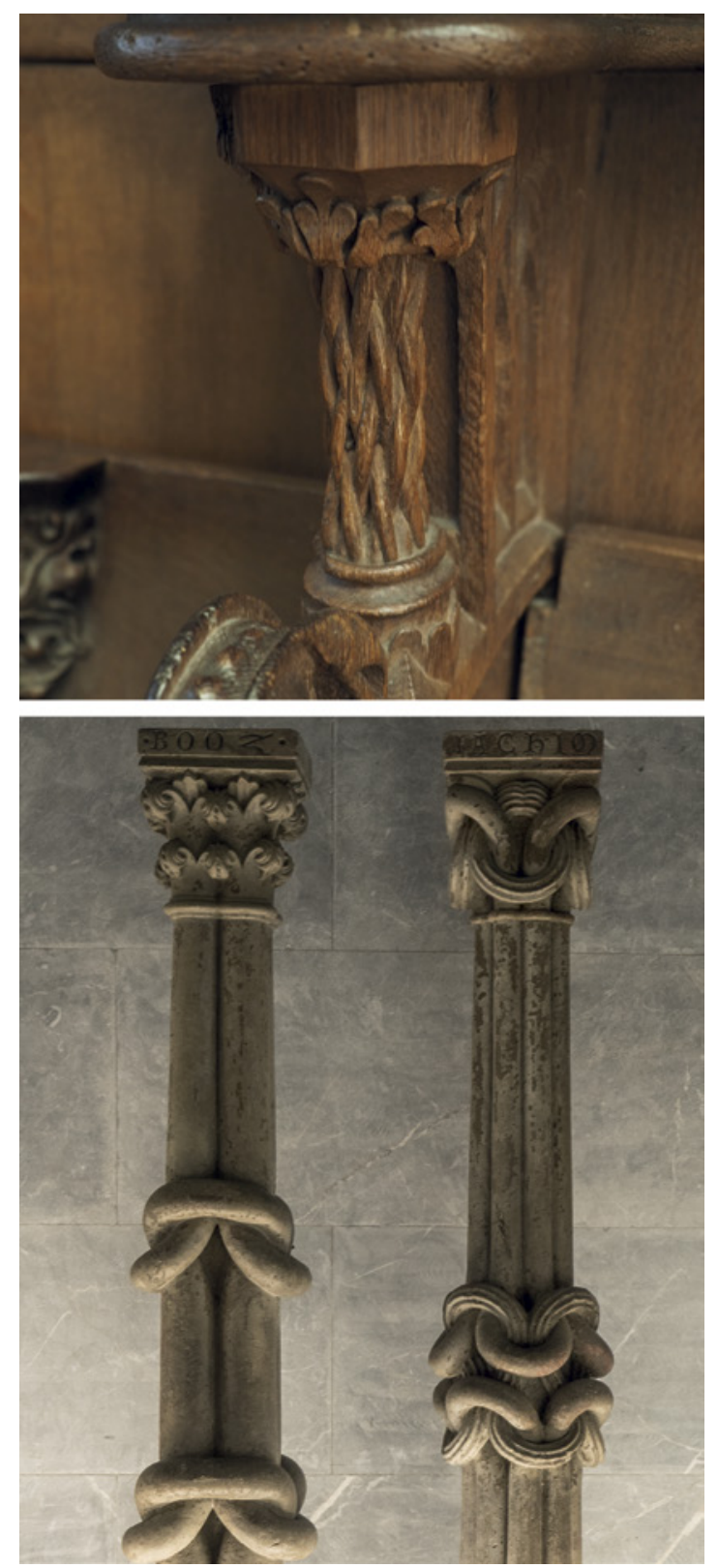

FIGURE 19.16 Above: Jörg Syrlin the Elder and Michel Erhart, choir stalls of Ulm Minster with knot column (1469-1474). Below: Romanesque knot columns Jachin and Boaz, Würzburg Cathedral (ca. 1230) IMAGES (c) AUTHOR 
a multitude of sturdy colonnettes in the lower levels. Their combined impression and in particular their ornamented shafts refer to pertinent designs of the late Romanesque era.

In Ulm in the late 1460 s one could find - as far as is known at this point - for the first time the torsion motif on column shafts in three-dimensional form, as it would appear from the 1430 in northern Alpine painting in the works of Rogier van der Weyden and other, later artists. In Ulm there was the addition of further motifs known from Romanesque architecture, such as scaled patterns and knot motifs on column shafts. In particular, the knot motif on column shafts is generally so rare during the Middle Ages that the precise reference to old Romanesque examples is rather evident. The Romanesque works newly studied by Jörg Syrlin and his workshop from 1468 onward may actually have looked like the exemplar of a Romanesque knot column still preserved in neighbouring Augsburg in the church of St George, consecrated in 1142.

In 1475, two rows of choir stalls were installed in the already mentioned collegiate church of Moosburg, closely connected to the Landshut ducal court, in which diverse Romanesque motifs displayed in Ulm also appear. They occur together with branchwork motifs (Astwerk) and a rich, vegetal ornamentation reminiscent of Romanesque models. Branch tracery is also included. The Moosburg stalls are remarkably dependent on the slightly older stalls in Ulm, even if their master is unknown. ${ }^{78}$

In Ulm as well, the innovative study and the revival of Romanesque architectural motifs, for the first time ascertainable by means of the three-part sedile from 1468, must have become popular. For example, in the Ulm Municipal Museum, a wooden column is preserved that comes from a citizen's townhouse and is dated to 1482 [Fig. 19.20]. It alludes to a Romanesque cubiform capital as well as typical Romanesque ornamented shafts. This Ulm column is also highly reminiscent in its proportion and ornamentation of the above-mentioned, probably only slightly older columns in the Chapel of the Holy Sepulchre in Bruges, even though no direct connection will be proposed in this case.

In the present survey, Ulm is an example with a certain hybridity, for there a carpenter, together with other wood sculptors, was first responsible for this study and reactivation of Romanesque models for the then-current art production in the genre of microarchitecture. It is, however, rather unlikely that this artistic process may have happened independently of the local architect in charge, i.e. a trained stonemason.

78 Dichtl R., "Das Moosburger Chorgestühl”, Heimatverein Moosburg a.d. Isar (ed.), Unser Moosburg 7 (1988) 127-136. 
From 1465 the master builder (Werkmeister) of Ulm Minster was Moritz Ensinger (ca. 1430-ca. 1483), who had succeeded his famous father, Matthäus, in this office. ${ }^{79}$ The pieces of architecture in Ulm that can be ascribed to him, including the monumental Ulm sacrament house of the Minster, ${ }^{80}$ completed in 1472 in the direct vicinity and conceptional context of Syrlin's sedile, do not display a reception of Romanesque stylistic elements. Nonetheless, in their early and innovative use of spiral shafts and stands, ${ }^{81}$ branchwork, ${ }^{82}$ and bent pinnacles, ${ }^{83}$ in conjunction with a disturbing renunciation of symmetry at some points, ${ }^{84}$ Moritz Ensinger's architecture attests to his willingness to ponder fundamental traditional qualities of building styles and even to question their validity from case to case. For Achim Timmermann, by means of the microarchitecture of his sacrament house Moritz Ensinger had intended to provide a potent pattern of his intellectual as well as artisanal prowess:

If Moritz Ensinger were indeed the artistic mastermind behind the sacrament house - and the stylistic and circumstantial evidence suggests that he was - it can be argued that it was this tabernacle, the tallest and most complex anywhere in existence, that eventually, in 1465 , won him his place at the head of the Ulm workshop. Demonstrating technical mastery, competence in logistic matters, but above all, unprecedented formal inventiveness, the sacrament house represents the artistic counterpart

79 So far, there is no monograph dedicated to Moritz Ensinger.

8o On the not yet completely researched sacrament house in Ulm, see Gropp D., "Der Prophetenzyklus am Sakramentshaus des Ulmer Münsters", in Reinhardt B. - Roth M. (eds.), Hans Multscher. Bildhauer der Spätgotik in Ulm, exh. cat., Ulmer Museum (Ulm: 1997) 145-164; Frebel V., "Das Ulmer Sakramentshaus und sein Meister", Ulm und Oberschwaben 44 (1982) 239-252; on Ulm, see Timmermann, Real Presence 80-89.

81 Moritz Ensinger's design, executed in $1462 / 1465$, does not yet include this motif; repository: Ulm, Stadtarchiv, draft no. 12.

82 Ascertainable on the Ulm sacrament house as a bracket for an Old Testament prophet, which was probably created shortly after 1467 by a pupil of Hans Multscher (Gropp, "Der Prophetenzyklus"). It was Anneliese Seeliger-Zeiss who first stressed the importance of Ulm as the early and innovative centre of branchwork applications in the 1460s: Seeliger-Zeiss A., Lorenz Lechler von Heidelberg und sein Umkreis. Studien zur Geschichte der spätgotischen Zierarchitektur und Skulptur in der Kurpfalz und in Schwaben (Heidelberg: 1967) here 43-49.

83 Bent pinnacles are included in the sacrament house on the second canopy register (ca. 1470) as well as in the design, also attributed to Moritz Ensinger (Riss B, London) for the Ulm west tower ca. 1470 .

84 Visible even in the early design drawing; Ulm, Stadtarchiv, draft no. 12. Körner chose for related phenomena the term of gestörte Form (disturbed form): Körner H., "Die gestörte Form in der Architektur des späten Mittelalters", in idem, Blickende Leiber, lebendige Farbe und Randfiguren in der Kunst. Kunsthistorische Aufsätze (Berlin: 2011) 135-154. 
to an inaugural speech, spelling out the agenda of its author. In some ways, the tabernacle may also be compared to a three-dimensional pattern book or architectural dictionary. 85

In 1493, humanist Hartman Schedel particularly mentioned the Ulm sacrament house together with the choir stalls in his Weltchronik as a remarkable work: 'ein mercklich köstlich und wercklich sacrament gehews auch gestüle in die chore'. 86

The Ulm project of building and furnishing the Minster, connecting diverse artistic genres, may have, from the late 1460 s, played a pioneering and key role in relation to the new ideas and the vital potential of Romanesque architecture. It is probably not by chance that the microarchitectural framing of intellectual heroes from pagan Roman and Greek antiquity by Jörg Syrlin the Elder on sedile and choir stalls, as well as the historicizing interpretation of Romanesque remains at the Wiblingen monastery by Felix Fabri, originate de facto in the same artistic and intellectual circle. All of these people were not only contemporaries, but also almost neighbours in the imperial town of Ulm. I shall return to this theme when investigating additional patrons, audiences, and personal networks.

But first, this condensed and by no means complete survey of some areas of innovative interest in Romanesque architecture taking place in the pictorial arts during the fifteenth century north of the Alps needs to be strengthened. It will be underpinned by discussing a further area of the reception of Romanesque style: i.e. the contemporaneous treatment and the recontextualization of spolia from buildings of the Romanesque era. Although this topic has already brought forth a lively scholarly debate, it has not yet received the full attention it needs.

\section{A New Boom of Romanesque Building Spolia}

From the 1480 os onwards, architectural spolia from the Romanesque era were integrated into an increasing number of new buildings in a contrasting modern style in Germany. Among these examples of reuse in prominent places were a striking quantity of elaborate and sculpturally ornamented church portals. In some cases, these older works had to be rearranged or were in part created from scratch. Different strategies for the preservation of the status quo,

85 Timmermann, Real Presence 88.

86 Schedel et al., Liber chronicarum CxcI. 
for revival, for repairs done in the style of the existing structures, and for new formulations may be observed.

In some instances of the reuse and revival of Romanesque architectural sculpture, the works in question were key works of Romanesque art that by such means have been preserved intact to this day. An example is the relocation of the Goldene Pforte (Golden Gate) at the southern entrance of the collegiate church at Freiberg in Saxony, when the church as a whole was newly built in modern Gothic style from 1484 on. ${ }^{87}$ The Goldene Pforte is an unusually elaborate figured portal in the guise of a rounded arch with richly decorated jamb steps and archivolts sculpted ca. 1225/1230. It represents one of the oldest figured portals in the German-speaking regions. Scholarship generally assumes that the portal originally marked the western main entrance of the Freiberg church. The Romanesque church was destroyed in 1484 during a fire in the city and was replaced subsequently by a completely new construction, a hall-type church in the gothic style.

Despite the complete abandonment of the previous building, the portal was carefully disassembled. Then, with almost archaeological meticulousness, it was correctly reassembled in the new location. Great appreciation of an older sculpted work of art is hereby expressed. Who in Freiberg decided to handle a work of art - one that had long since become obsolete - with this kind of conservative care can no longer be ascertained in detail. Freiberg Cathedral had become in 1480 the church of a newly founded college, closely connected to the electoral Saxon court. Single canons took up important political tasks at the Saxon court and maintained strong ties to the Saxon state university at Leipzig.

In other regions, a similar handling of elaborate architectural sculpture from the Romanesque era may be observed around this time. One problem in dealing with this topic consists in the fact that it goes beyond the possibilities of art historical style-analytical methodology. Even though it is possible to narrow down the original period of creation of the Romanesque spolia, as far as the type and chronology of the reuse, and sometimes even its factuality, are concerned, it is rarely possible to come to an agreement in art historical scholarship. ${ }^{88}$

87 Magirius H., Der Dom zu Freiberg (Lindenberg: 2013) 15-23.

88 Among the constellations and artefacts that art historical scholarship has so far not been able to date conclusively belongs the southern porch of Innichen; cf. Dobler E., "Die Portalschauwand an der Südseite der Stiftskirche von Innichen", Wiener Jahrbuch für Kunstgeschichte 25 (1972) 177-186; Dobler E., "Zum Lettnerproblem und zum Südportal an der Stiftskirche von Innichen", Wiener Jahrbuch für Kunstgeschichte 28 (1974) 185-187. The same is the case for Schöngrabern, cf. Fillitz H. (ed.), Schöngrabern, coference volume 
In the 1970s, Erika Doberer proposed several groups of Romanesque building sculptures for discussion as having been reused in the Alpine region during the final third of the fifteenth century. Particularly interesting and widely accepted by scholarship are her findings about a building campaign at the Benedictine monastery Millstadt, in Carinthia, where a whole range of types of Romanesque building sculptures, such as choir screen figures, pulpit reliefs, and mullions, were put into new contexts. Here, an older monastery was adapted for the purpose of the military order of St George, founded on 1 January 1469 by Emperor Frederick III and Pope Paul II (r. 1464-1471) for defence against the Turks.

Among other things in Millstadt, a new portal was composed from Romanesque spolia in the redesigned cloister [Fig. 19.17]. ${ }^{89}$ The cloister itself was newly covered with a Romanesque-type groin vault, and therefore belongs conspicuously to the almost contemporaneous group of fifteenth-century interiors created with an orientation towards traits of Romanesque style already presented above. The above-mentioned Salzburg palas extension of ca. $1480 / 1485$ seems to be a stylistically similar example. In Millstadt, a mural dated by inscription to 1499 provides a secure terminus ante quem. Perhaps Emperor Maximilian I, who was a main patron of the new order, promoted the building project. Before the 1490 s, the order would have made the construction of defence structures its main priority. Nonetheless, one should try further to specify the date.

During the same time, in the 1490s, the Wasserburg master builder Wolfgang Wiser (also: Wiesinger; ca. 1450-1507) rebuilt the church of the Nonnberg monastery in Salzburg. ${ }^{90}$ Apart from artful architectural innovations, such as arched rib vaults, and the conspicuous staging of fake architectural auxiliary constructions, such as ribs seemingly mounted at random, the new, southern

of the international Colloquium of the Austrian National Commitee of the C.I.H.A. 17-18 September 1985 (Vienna: 1985); Doberer E., "Abendländische Skulpturen des Mittelalters und ihre metamorphischen Veränderungen”, Wiener Jahrbuch für Kunstgeschichte 46/47 (1993/1994) 161-163; Pippal M., Die Pfarrkirche von Schöngrabern. Eine ikonologische Untersuchung ihrer Apsisreliefs, Schriftenreihe der Kommission für Kunstgeschichte der Österreichischen Akademie der Wissenschaften 1 (Vienna: ${ }^{2}$ 1996). Similar debates were conducted about the so-called Schottenportal in Ratisbon.

89 Doberer E., "Eingefügte Fragmente am Kreuzgangsportal der Millstätter Stiftskirche", Wiener Jahrbuch für Kunstgeschichte 24 (1971) 49-58.

90 Pretterebner G., "Baumeister Wolf Wiser", Burghauser Geschichtsblätter 30 (1970) 5-43; Bischoff F., Burkhard Engelberg 'der vilkunstreiche Architector und der Statt Augspurg Wercke Meister'. Burkhard Engelberg und die süddeutsche Architektur um 1500. Anmerkungen zur sozialen Stellung und Arbeitsweise spätgotischer Steinmetzen und Werkmeister (Augsburg: 1999) on Wiser: 344. 


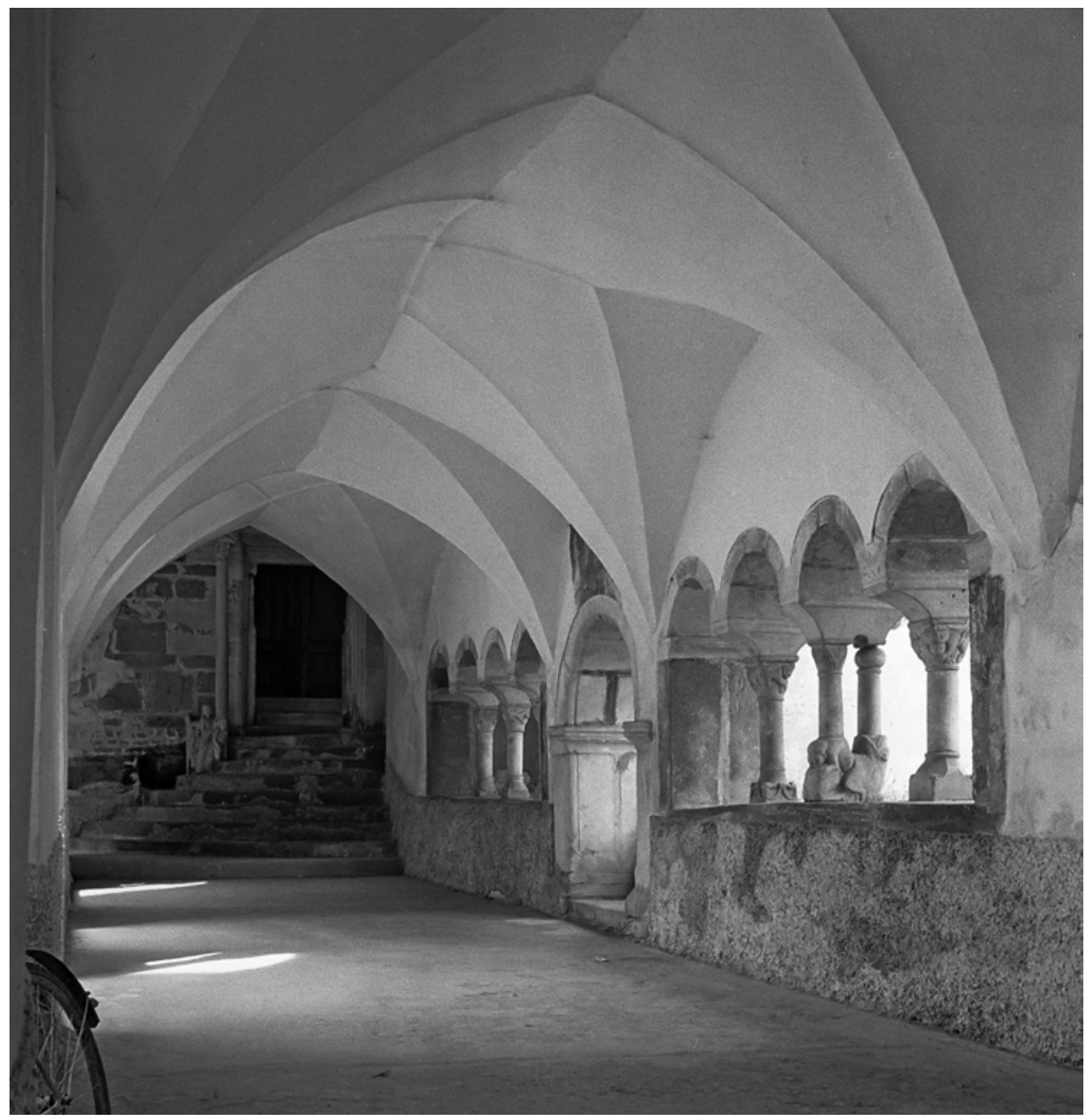

FIGURE 19.17 Monastery of Millstadt, Romanesque Renaissance vault (ca. 1490) IMAGE (C) FOTO MARBURG 


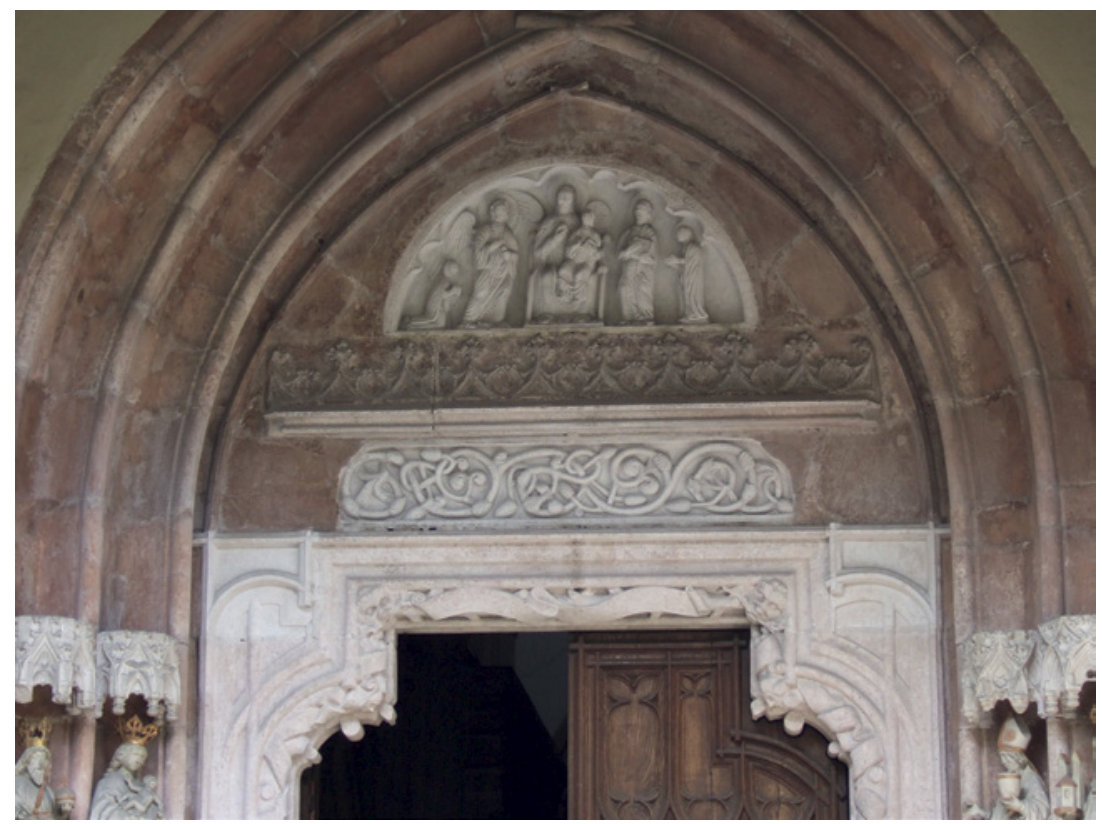

FIGURE 19.18 Wolfgang Wiser, (southern) porch with Romanesque spolia (1499), Salzburg, Nonnberg monastery IMAGE (C) AUTHOR

porch of the monastic church, created elaborately in marble starting in 1497, incorporated Romanesque spolia [Fig. 19.17]. Wiser added an architrave decorated with tendrils and a figured tympanum. In 1499 an invoice lists 'Item mer ainen lanngen alten stain von der allten tür auf die new gross Tür' (Further, a long, old lintel from the old portal on top of the new grand door). ${ }^{91}$

In Frankfurt/Main, the merchants' settlement west of the Staufian-era city had established its own chapel with the patrocinium of 1219, which had from the start been furnished elaborately with two sculpted Romanesque porches. The larger the two was even signed with an inscription: 'Engelbertvs f(ecit)'. It thus presents an early example of true or supposed artists' self-assurance. From ca. 1500, the nave and the western façade of the St Leonard church were demolished and replaced by an elaborate hall church. As in Freiberg or Nonnberg, the new Frankfurt building was designed in a modern Gothic style. Around 1507, in the new building's north wall, the two Romanesque porches from the original building were integrated. In contrast to the Freiberg porch,

91 Tietze H., Die Denkmale des Adeligen Benediktiner-Frauen-Stiftes Nonnberg in Salzburg, Österreichische Kunsttopographie 7 (Vienna: 1911) XXII. 
several blocks of the original Romanesque building decoration had been lost or resisted the integration in the new architectural context. In these places, the Romanesque decorative system was taken over and completed in stylistically matching forms [Fig. 19.19]. It is noticeable that particularly in these stylistically sensitive positions, motifs of the spiral column were used, which were interpreted here as evocations of the pertinent Romanesque motifs rediscovered in the North only by the mid-fifteenth century.

These examples of diverse approaches towards artefacts of the Romanesque era attest that they met with an empirical interest adopted by the painters and humanists of the ongoing fifteenth century, but were also considered within the framework of real building practice in their materiality.

New concepts for the dealings with the artefacts of a long-ago period needed to be developed. Old masonry needed to be translocated in accordance with the rules and principles of its reintegration and of the formal integration into stylistically diverse new buildings. ${ }^{92}$ In Frankfurt there was an effort made to achieve a stylistically harmonic result for the integrated elder building parts in their new setting; in Salzburg the aesthetic contrast was not solved, or even appreciated. Only one further small step needed to be taken to make the newly acquired knowledge about the characteristics in terms of style and motif of such architectural decoration available for new designs.

The newly designed buildings mentioned above in connection with the Albrechtsburg, buildings that picked up style characteristics of long-ago architecture, did so in a way that allows for no argument about the precise sources of this stylistic takeover and its adaptation. In this case there can only be arguments made on the basis of style analysis, since essential principles of modern Gothic building were overruled.

In comparison, the analysis of motifs from architectural sculpture offers further possibilities for the identification of precise models. The building master Hans Schweiner (1473-1534) was going to adopt complete imitations of older building sculpture after Romanesque models at Worms Cathedral and at the Romanesque church in his hometown of Weinsberg for his new design of the western tower of the municipal church of Heilbronn from $1513 .{ }^{93}$

92 The integration of older figured porches into newly built churches was not a new phenomenon. In the newly built Ulm Münster the porch of the previously existing city church, which was situated outside the city walls, was integrated. Around 1377, these remains were not yet very old. In the thirteenth century, an older porch was incorporated into the western building of the newly constructed cathedral of Notre Dame de Paris.

93 Farys S., Bauen im reichsstädtisch-reformatorischen Heilbronn. Eine exemplarische Werkanalyse zu Hans Schweyner von Weinsberg (1473-1534) (Münster - Hamburg Berlin - Vienna - London: 2004); Hoppe S., "Stildiskurse, Architekturfiktionen und Relikte. 


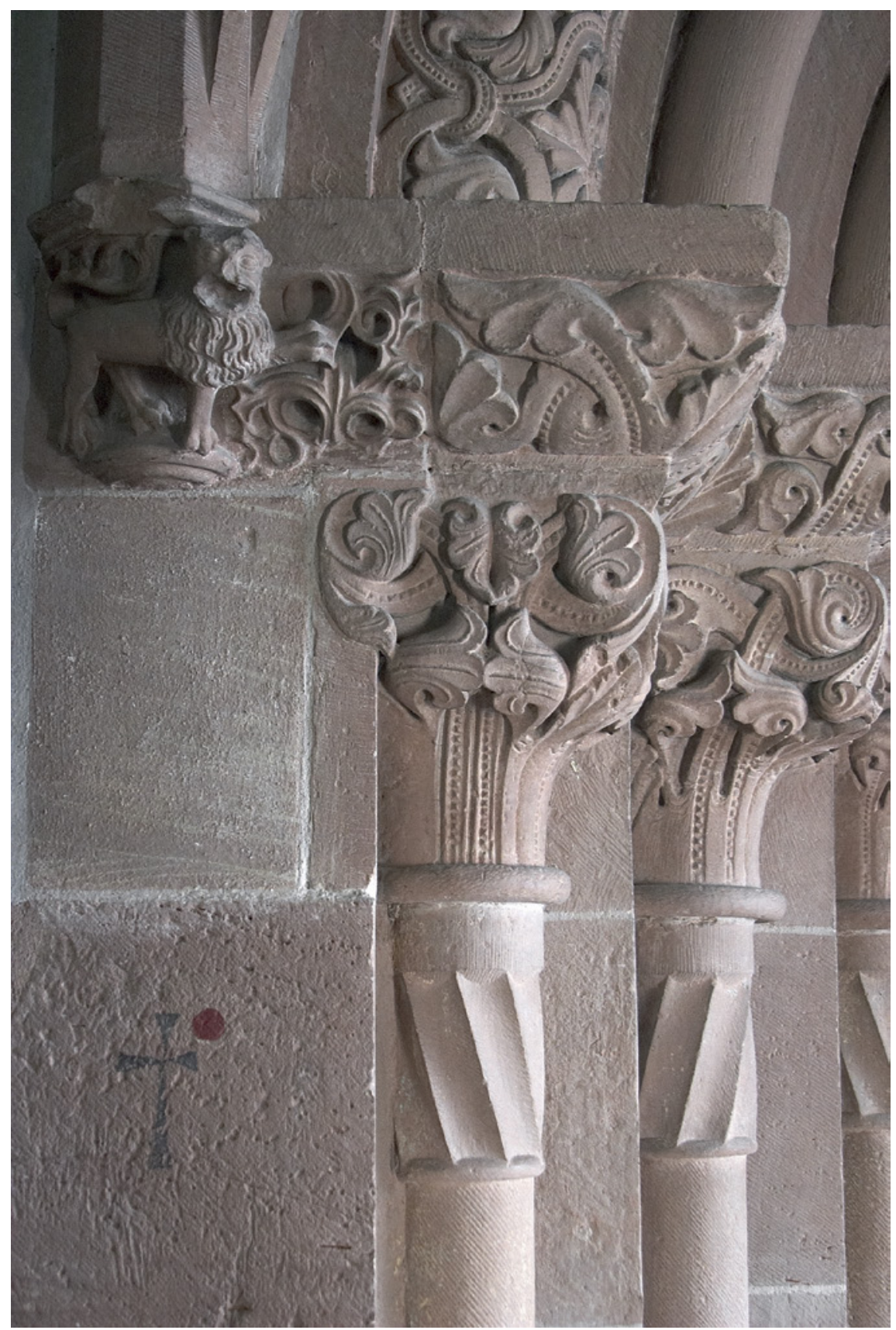

FIGURE 19.19 St. Leonard church of Frankfurt am Main, portail with Romanesque spolia (ca. 1507)

IMAGE (C) AUTHOR 
As late as the 1560s, the ancestral castle of the Echter family of Mespelbrunn, who belonged to the lesser nobility, was ornamented with numerous newly created capitals and columns in combination with a Vitruvian architectural order. ${ }^{94}$ There are many more examples from this later period.

The examples for how to address Romanesque building sculpture and Romanesque buildings gathered in this section attest in total to a new interest in the local material remains of a building art that presented itself formally as 'older', one that had 'gone out of use long ago', developing during the final third of the fifteenth century in Germany. These creations are consistently of social and artistic relevance and, as a rule, of aesthetic aspiration. Their difference from traditional regional northern Alpine artistic work ought to easily become obvious through contemporaneous observation. No specialist was needed to recognize the differences from the current Gothic style. Even for a non-artistic audience the pre-Gothic stylistic language had reached a new importance and value.

From the chronology reconstructed here, there is evidence that the new palace building at Meißen from 1471 takes a key position in the development of the northern Alpine architecture during the second half of the fifteenth century. A new kind of practical and productive engagement with an older artistic era can be traced: an era that was clearly recognized as being stylistically different. This engagement was going to become more frequent over the subsequent years and finally would feed into the broader architectural development of the northern Alpine Renaissance.

Before this date, it was particularly painted and small-scale imitations of architectural designs in wood and stone (microarchitecture) that had included similar elements of a pre-Gothic architectural language. Thereby, they had created new meanings and in general new references to the history of antiquity. Such an approach, developed from the 1430 s in Netherlandish painting, was going to be received particularly during the 1450 s and 1460 s in some artistic centres in Germany, attested by the painterly work of Hans Pleydenwurff or

Beobachtungen in Halle, Chemnitz und Heilbronn zum Einfluss der Bildkünste auf mitteleuropäische Werkmeister um 1500", in Bürger - Klein, Werkmeister der Spätgotik 69-91. Hoppe S., "Stil als Dünne oder Dichte Beschreibung. Eine konstruktivistische Perspektive auf kunstbezogene Stilbeobachtungen unter Berücksichtigung der Bedeutungsdimension", in Hoppe - Nußbaum - Müller, Stil als Bedeutung in der nordalpinen Renaissance 48-103, see 76 (with Fig.). 
the sculptural work of Jörg Syrlin the Elder. But only at the clectoral Saxon court were appropriate consequences for monumental buildings drawn. These buildings, at least in part, still belong to the main works of art history of this period. Later works followed in the early 1480 os.

Single commentaries, expressed by prominent contemporaneous exponents about diverse representatives of the Romanesque building style, refer to the fact that it was not the art historical era of the 'real' Romanesque, as defined and termed only in the nineteenth century, that was to be studied anew and reactivated for the contemporaneous art of building. Numerous factors seem to attest that at the time the stylistic continuity of ancient buildings was presumed to have lasted up to the times of the Carolingians and Staufians. ${ }^{95}$ Even rather recent buildings could be understood as points of reference for a 'jtzige widererwaxsung'96 (regrowth) (Dürer) to ancient artistic levels. At the time, such a semantic connection between Romanesque building style and ancient history was not solely a German but a pan-European phenomenon. This notion was adopted north of the Alps during the course of the fifteenth century.

When reactivating obsolete forms of art and finding a new use for appropriate artefacts, the focus could be on a more intellect-based approach to the sheer beauty and the potential as an aesthetic model of ancient art, as well as on a politically usable reference to an age and antiquity that bestowed historical and exemplary prestige. Both approaches had already been developed and applied in Italy.

In the North, new actors, such as schoolteachers, court scribes, and learned advisors and councillors who had received a humanist education in Italy, worked from the 1440 s onwards. They became the new rank of experts for the learned interpretation and revival of an ancient quality of art.

The second approach, i.e. the political use of ancient cultural objects, could be observed also in neighbouring regions in the European North. Such redeployment happened, for example, increasingly in Burgundy, where in particular during the rule of Charles the Bold (r. 1467-1477) innovative possibilities to legitimize the ruler's authority by ancient history were thereby examined. ${ }^{97}$

95 Cf. also Günther, "Vorstellungen” 106.

96 Rupprich H. (ed.), Dürer. Schriftlicher Nachlaß, vol. II (Berlin: 1966) 144.

97 Vanderjagt A.J., "Classical Learning and the Building of Power at the Fifteenth-Century Burgundian Court", in Drijvers J.W. - MacDonald A.A. (eds.), Centres of Learning:Learning and Location in Pre-modern Europe and the Near East (Leiden - New York - Cologne: 1995) 267-277; Franke B., "Ritter und Heroen der 'burgundischen Antike'. Franko-flämische Tapisserie des 15. Jahrhunderts", Städel-Jahrbuch N.F. 16 (1997) 113-146; Ehm-Schnocks P., “Très invaincu César'. Antikenrezeption am burgundischen Hof unter Philipp dem Guten und Karl dem Kühnen", in Suntrup R. - Veenstra J.R. - Bollmann A. (eds.), The Mediation 
In view of this diverse material, which originated in different artistic genres, the central issue must be the query regarding the personnel and the intellectual horizons to be addressed by these architectural ideas. Some of the local artists concerned were briefly introduced above. Since in those circles, however, direct contacts with Italy and Italian thought were then hardly ever relevant at the time and can only be proven in some exceptional cases, one must examine the wider sphere of personnel involved in innovative art projects, i.e. the circles and networks of patrons, advisors, and transmitters. Numerous and conspicuous are the references to literates who should be counted as humanists and to patrons influenced by humanism, who turn up every so often while gathering eyewitness accounts of Romanesque reception. In part, they even appear several times in diverse functions. ${ }^{98}$

It comes as no surpise that the intellectual and educational movement of humanism, which spread from Italy, also concerned itself with issues of cultural reactivation of ancient art and architecture. So far, art historical scholarship has supported this connection between learned, humanist-trained personnel and the arts for the fifteenth century as an Italian specialty that only in the wake of the sixteenth century was more strongly received north of the Alps. Nonetheless, the 'diffusion' of applicable humanist ideas, to pick

of Symbol in Late Medieval and Early Modern Times. Medien der Symbolik in Spätmittelalter und Früher Neuzeit (Frankfurt a. M.: 2005) 275-295; Welzel B., "Schenkung - Territorium. Zum Reliquiar Karls des Kühnen von Gérard Loyet”, in Kruse - Thürlemann, Porträt Landschaft - Interieur 203-217.

98 In the present study, 'humanism' is supposed to be understood as rather broadly defined, beyond the older definition, for example, in Kristeller. In this way, it is possible to draw on more recent developments in the scholarship concerning humanism, in which the entangled or networking character of the humanist educational movement is examined and productive transformations are considered as much as the relatively strict orientation towards the Italian original ideas. The term 'humanism' ought to be seen in this context as an intellectual movement, intentionally encompassing all spheres of life with a link to antiquity, thereby opening up the narrower and stricter perception of humanism as literary phenomenon. Fundamental examples of innovative approaches to forms of research regarding the early Renaissance humanism north of the Alps (while mentioning the relevant older literature): Helmrath - Muhlack - Walther, Diffusion des Humanismus.

On the relationship between Renaissance humanism and courtly life, see the critical research survey in Hirschi C., "Höflinge der Bürgerschaft - Bürger des Hofes. Zur Beziehung von Humanismus und städtischer Gesellschaft", in Müller G.M. (ed.), Humanismus und Renaissance in Augsburg. Kulturgeschichte einer Stadt zwischen Spätmittelalter und Dreißigjährigem Krieg, Frühe Neuzeit 144 (Berlin - New York: 2010) 31-6o. Cf. also the newer case studies on particular circles of humanists: Müller H., Habit und Habitus. Mönche und Humanisten im Dialog (Tübingen: 2006); Landois A., Gelehrtentum und Patrizierstand. Wirkungskreise des Nürnberger Humanisten Sixtus Tucher (1459-1507) (Tübingen: 2014). 
up a term coined by the historians Johannes Helmrath, Ulrich Muhlack, and Gerrit Walther, ought to be in certain cases definitely predated to the fifteenth century. ${ }^{99}$

Back in the Augsburg of the 1450s, a tight connection between patrons, educated and networked within the parameters of early humanism, and a programmatically used reception of Romanesque forms, can be reconstructed as the identification of the city and its elites as originating in pagan antiquity, going back to a time even before the arrival of the Romans. Augsburg, therefore, certainly belongs to the very early centres of humanist activities in Germany, and may accordingly hold a certain exceptional status. It was not only their studies at Italian universities during the fifteenth century that brought the members of the Augsburg elite into contact with the various new ideas of Renaissance humanism. Augsburg was, as mentioned above, at least visited by Italian humanists during their travels north of the Alps and was considered a place of intellectual exchange, where one could find competent and attentive interlocutors.

An equally close connection between humanist personnel and artistic production may also be shown for the slightly later project of the choir stalls of Ulm Minster. Scholarship has not yet fully investigated this project as a humanist one, in contrast to those in Augsburg. The imperial city of Ulm offered a particularly well-prepared breeding ground for such a innovative project. Here, quite early in the fifteenth century, it had become the norm among the leading families of the patriciate and other similar societal groups to connect narratives of their own origins, which had deliberately been moved back to pagan antiquity, with solid humanist studies and activities in the fields of literature and the visual arts. ${ }^{100}$ Humanist education abroad and activities at home presented a qualitative rank distinguishing the families who considered themselves part of the old nobility. It therefore found a comparably wide and early dissemination within the urban elites. ${ }^{101}$

99 Helmrath - Muhlack - Walther, Diffusion des Humanismus.

100 On surveys on the early reception of humanism in Ulm that may so far be found in dedicated investigations, see Joachimsohn P., "Frühhumanismus in Schwaben", Württembergische Vierteljahrshefte für Landesgeschichte 5 (1896) 63-126, 257-291; Mertens, "Eberhard im Bart und der Humanismus" 42-43; Klingner J., Minnereden im Druck. Studien zur Gattungsgeschichte im Zeitalter des Medienwechsel (Berlin: 2010) 139-153.

101 Lang S., Die Patrizier der Reichsstadt Ulm. Stadtherren, Gutsbesitzer und Mäzene (Ostfildern: 2011); Fieg O., "Das Ulmer Patriziat zwischen Zunftbürgertum und Landadel", in Hengerer M. - Kuhn E.L. (eds.), Adel im Wandel. Oberschwaben von der Frühen Neuzeit bis zur Gegenwart, vol. II (Ostfildern: 2006) 631-642. 
The city council had been responsible for the furnishing of the Ulm parish church ever since it gained jurisdiction in ecclesiastical matters in 1396. It gave orders to the three members of the body of church wardens, two of whom hailed from the patriciate. ${ }^{102}$ The church wardens also chose the parish priest of the Minster. The long-serving parish priest Jodocus Clamer (in office $1443^{-1470}$ ), as a highly educated and intellectually influential personality, might be considered as being responsible for and as one of the decision-makers in the case of the new furnishing programme. He was related to a number of patrician families, had studied canon law in Heidelberg and Vienna, and maintained close contacts with the Augsburg clergy. Altogether, he belonged to a rather conservative movement in ecclesiastical matters.

This orientation was to change direction during the tenure of his successor, Dr Heinrich Neithardt the Younger (ca. 1425/1430-1500), who had studied in Paris and then had gained his doctorates in ecclesiastical law as well as in theology in Pavia. In the 146os, he was in close exchange with compatriotic humanist authors, such as Albrecht of Eyb (1420-1475), and with other humanists in the southern German regions. Back in the 146os, Neithardt had already campaigned from Constance for issues concerning the Minster at Ulm. In 1468, there was talk of a design for or a copy of a depiction of the Last Judgement in Basel that he is supposed to have supported financially. ${ }^{103}$ Neithardt belonged to a family that distinguished itself in multiple ways through its erudition. In the fifteenth century, it had traced back the family's noble origins to the Norici, who had reached Bavaria from Armenia during antiquity. ${ }^{104}$

From the late fourteenth century, members of this family had been directing the Ulm chancellery school, and they later expanded it into a widely renowned educational institution. An elder Heinrich Neithardt had donated 300 volumes of his unusually rich library to the city in 1437/1443, and Hans Neithardt from the younger generation (ca. 1430-ca. 1490) was going to support translations of Latin classical texts and would help bring them into print during the $1480 \mathrm{os}$.

These same people responsible for the furnishings of Ulm Minster were at the same time linked to a complex local configuration consisting of additional civic institutions and local people influenced by humanism. Several members of the Neithardt family would subsequently preside over the above-mentioned chancellery school. The Ulm Latin School also held supraregional importance,

102 Vöge, Jörg Syrlin 26. Urbach D.U., Weltgericht und städtische Selbstdarstellung. Das Wandgemälde am Triumphbogen des Ulmer Münsters (Freiburg: 2001) 151.

103 Urbach, Weltgericht 158, and Rott H., Quellen und Forschungen zur südwestdeutschen und schweizerischen Kunstgeschichte im 15. und 16. Jahrhundert, vol. 2: Altschwaben und die Reichsstädte (Stuttgart: 1934) 72.

104 Fabri, Tractatus de civitate Ulmensi, trans. Reichert 93-95. 
since under its rector Heinrich Better it had established an obvious earlyhumanist profile by the middle of the fifteenth century. In 1460, it employed the famous 'wandering humanist' and eager promotor of the new ideas Peter Luder as teacher, who in turn had been attracted by the impressive number of pupils at the school. Wilhelm Vöge wondered if a young humanist teacher from this school, Theobald Seidener, could have been the author of some of the tituli on the Ulm choir stalls. ${ }^{105}$

Heinrich Steinhöwel (1410-1479) - an Ulm city physician educated in Padua, humanist, and book entrepreneur - belonged in particular to the supraregionally renowned and connected people. ${ }^{106}$ In 1454 , he even became a personal physician to the Burgundian Duke Philip the Good. The entire range of Steinhöwel's interests cannot be presented presented here, but he acquired a particular reputation as an editor of classical texts and as a translator of renowned classical authors, as well as Italian humanists, into the German vernacular language. To disseminate these texts also through the new medium of book printing, he financially supported the ambitious printer Johann Zainer in the establishment of the first printing press in Ulm and was responsible for the introduction of innovative and high-quality woodcut illustrations in his works. ${ }^{107}$ Although we do not know for sure the identities of the artists of the 191 stylistically new woodcuts in the Buch und Leben des hochberühmten Fabeldichters Aesopi of 1476/1477, Steinhöwel's humanist projects confirm his intense relationship with the visual arts. ${ }^{108}$ Altogether, the intellectual scene in Ulm shows a conspicuously tight connection between early humanist studies and aims, literary projects, and the visual arts.

As in the case of the Ulm Minster furnishings, in the case of the Landshut ducal court the degree to which early humanism was embedded in pan-European relations has been rather underestimated for a long time. Nonetheless, back in 1459, Duke Georg's father, Duke Ludwig the Rich (1417-1479), had called the renowned humanist and Doctor juris utriusque Martin Mair (ca. 1420-1480) to join his court council. Mair maintained tight contacts with numerous early

\footnotetext{
105 Vöge, Jörg Syrlin 40.

106 Terrahe T., Heinrich Steinhöwels 'Appolonius' (Berlin - Boston: 2013); Dicke G., Heinrich Steinhöwels Esopus und seine Fortsetzer: Untersuchungen zu einem Bucherfolg der Frühdruckzeit (Tübingen: 1994); Amelung P., Der Ulmer Aesop von 1476/77, comment (Ludwigsburg: 1995).

107 Worringer W. - Benz R. (eds.), Buch und Leben des hochberühmten Fabeldichters Aesopi (Munich: 1925); Worringer W., Die altdeutsche Buchillustration, 3rd ed. (Munich: 1921) 44; Fischel L., Bilderfolgen im frühen Buchdruck. Studien zur Inkunabel-Illustration in Ulm und Strassburg (Constanz - Stuttgart: 1963).

108 Cf. Vöge, Jörg Syrlin 3 .
} 
humanists. ${ }^{109}$ In 1454, Enea Silvio Piccolomini, who personally knew Mair, visited the duchy. Somewhat later, the two humanists conducted the famous exchange of letters in which they compared the ancient and modern conditions in Germany. When in 1472, after long preparations, a Bavarian university was finally founded in Ingolstadt, Mair held the foundation speech, which was enriched with references to ancient history.

From the beginning, this ducal institution was supposed to look after the new educational themes of humanism and of ancient tradition. ${ }^{110}$ The first chancellor, William of Reichenau, Bishop of Eichstätt (ca. 1426-1496) had received his doctorate from Padua. The university stood in a long-established local tradition of humanist interests. Between 1491 and 1495, the 'archhumanist' and poeta lareatus Conrad Celtis taught in Ingolstadt, where young Johannes Aventinus (1477-1534) would receive his formation as a humanist historian.

At the same time, the Munich branch of the Wittelsbach dynasty under Duke Albert (Albrecht) IV (1447-1508), who had been educated at the universities of Cologne and Pavia, worked on the construction of a dynastic and territorial identity, reaching far back into history. Despite all the inner-dynastic difficulties, from the middle of the fifteenth century a pan-dynastic Wittelsbach consciousness developed, expressed by the term 'House of Bavaria'. It quickly became the general principle of Alberts concept of "state". In this context, the 'unity of the Bavarian tribe, the long-ago creation of Bavaria as a political entity and the inclusion of the Wittelsbachs in the long and venerable series of the dukes' were emphasised. To revive these magnificent, and in part fictive, origins was the declared aim of Duke Albert. ${ }^{111}$

109 Märtl C., "Herzog Ludwig der Reiche, Dr. Martin Mair und Eneas Silvius Piccolomini", in Niehoff F. (ed.), Das goldene Jahrhundert der Reichen Herzöge, exh. cat., Museen der Stadt Landshut (Landshut: 2014) 41-54; Hansen R., Martin Mair. Ein gelehrter Rat in fürstlichem und städtischem Dienst in der zweiten Hälfte des 15. Jahrhunderts, Ph.D. dissertation (University of Kiel: 1992).

110 Schuh M., Aneignungen des Humanismus institutionelle und individuelle Praktiken an der Universität Ingolstadt im 15. Jahrhundert (Leiden: 2013); Fuchs F. (ed.), Humanismus in Ingolstadt, acts of the symposion 11-12 November 2011 in Ingolstadt (Wiesbaden: 2013).

111 Störmer W., "Die wittelsbachischen Landesteilungen im Spätmittelalter (1255-1505)", in Bäumler S. - Brockhoff E.M. - Henker M. (eds.), Von Kaisers Gnaden. 5oo Jahre Fürstentum Pfalz-Neuburg, exh. cat., Bavarian state exhibition Neuburg an der Donau (Augsburg: 2005) 17-23, here 21: 'die Einheit des bayrischen Stammes, die Entstehung Bayerns als politisches Gebilde in uralten Zeiten und die Einbindung der Wittelsbacher in die lange und ehrwürdige Reihe der Herzöge'; translation by Andrea Gáldy; cf. Moeglin J.M., "Die Genealogie der Wittelsbacher. Politische Propaganda und Entstehung der territorialen Geschichtsschreibung im Mittelalter", Mitteilungen des Instituts für Österreichische Geschichtsforschung 96 (1988) 33-54; Moeglin J.M., Les Ancêtres du prince, propagande politique et naissance d'une histoire nationale en Bavière au Moyen-Âge (1180-150o) (Geneva: 
In the case of the idiosyncratic imitation of Romanesque vaulted rooms in the Burghausen Residence around 1480, it may be assumed that this Wittelsbach building project was an experiment with a historical building style that was prompted by humanist notions of history and art. It was supposed to underpin the immensely long history of the Bavarian state, which went all the way back to late antiquity (the sixth century AD), of its dynasty and unbroken line of dukes. Perhaps it was intended to provide a model character of ancient artistry and magnificence. Obviously, the Burghausen project chose to rely far more closely on the architectural style then perceived as ancient than the palace buildings of their Saxon relatives had done a few years previously by means of a looser allusion to Romanesque role models.

There remains the issue of the conclusions to be drawn based on an ever more evident humanist background of turning towards the Romanesque as a medium for transmitting ancient art. What does it mean in relation to the electoral Saxon court, which seems to have been operating in a similar way relatively early on?

Thus far, the Saxon court has not been known for being influenced so soon by humanist education and ideas. The ruling brothers Ernest and Albert, born ca. 1440, still belonged to a generation of German princes in which a literary or humanist education did not yet count as an important cultural or political element to gain. ${ }^{112}$ In Saxony, an early engagement with humanist interests from the 145 os onwards took place at the electoral university at Leipzig. ${ }^{113}$ But court and humanist circles were not yet as closely connected, as had been the case in the South of Germany. It would take until 1486 for a university-educated teacher looking after the instruction of the next generation of princes to be mentioned in the records of the Saxon court.

There is no doubt that the innovative architecture in Meißen was practically designed by the then newly installed Landeswerkmeister (court architect) Arnold of Westfalen. It is also highly probable that Arnold had been responsible for Dresden Castle, started three years previously and planned in accordance with a different concept. So far, scholarship has not been able to establish Arnold's artistic lineage. After all, Stefan Bürger recently developed new ideas of Arnolds's education at the then renowned Viennese cathedral

1985); Dicker S., Landesbewusstsein und Zeitgeschehen. Studien zur bayerischen Chronistik des 15. Jahrhunderts (Cologne - Weimar: 2009). On the cultural politics of the Upper Bavarian line, cf. Dahlem A.M., The Wittelsbach Court in Munich: History and Authority in the Visual Arts (1460-1508), Ph.D. dissertation (University of Glasgow: 2009).

112 Cf. Deutschländer G., Dienen lernen, um zu herrschen. Höfische Erziehung im ausgehenden Mittelalter (1450-1550) (Berlin: 2012).

113 Bünz E. - Fuchs F. (eds.), Der Humanismus an der Universität Leipzig (Wiesbaden: 2008). 
workshop under the architect Lorenz Spenning. ${ }^{114}$ Whether the most important supraregional station of Arnold's education was thereby identified is still under debate. In any case, it means that additional transfer channels leading towards Dresden and Meißen have to be considered.

The examples of what was then a new reception of Romanesque style, gathered here loosely into a matching field of intellectual history, may suggest a similar intellectual background to have become effective at the electoral Saxon court. Therefore, the learned electoral Saxon councillor Dr Heinrich Stercker of Mellerstadt (ca. 1430-1483) ought to be brought into the discussion, even though thus far little attention has been paid to him. Jörg Schwarz recently compiled his biography, and thus traced his intensive intellectual roots in Italian and German early humanism. ${ }^{115}$

Dr Heinrich Stercker had studied in Leipzig from 1454 and belonged to an elite circle of early German humanists, including the experienced Peter Luder (ca. 1415-1472) and the young Hartmann Schedel (1440-1514). Stercker there had become familiar with the work of Enea Silvio Piccolomini, before he continued his studies in Italy, in Perugia. After his return to Saxony, the freshly graduated jurist first entered the services of the humanist Bishop Dietrich III of Meißen (Dietrich III. of Schönberg, ca. 1400-1476). In this role, he would lead the ecclesiastical tribunal of the diocese.

The moment of Stercker's transfer into the service of the electoral court is of the greatest importance. When he was promoted to his new position, not only did he gain important political and administrative duties, but we may assume that this office also would have provided him with decisive influence on the new artistic commissions of the electoral princes. In 1469, he was appointed an electoral councillor. It happened exactly in the short window of time in which the decision in favour of a new humanist, or rather Italian, orientation of the Meißen building project may have taken place. In the same year, he accompanied his prince to the imperial court. Dr Stercker served Elector Ernest as a learned councillor in important matters, probably to the very end of Sterckers life and he also participated in Duke Alberts's pilgrimage to Jerusalem in 1476.

Although we do not know Stercker's exact degree of involvement with the development of the architecture of his time, being a permanent member of the princely council with rich experience of courtly life made him clearly responsible for advice on such a sophisticated architectural project in a new

\footnotetext{
114 Bürger, "Herkunft des Landeswerkmeisters Arnold von Westfalen" 43-52.

115 Schwarz J., "Der sächsische Rat und Frühhumanist Heinrich Stercker aus Mellrichstadt (ca. 1430-1483). Eine biographische Skizze", in Bünz E. - Fuchs F. (eds.), Der Humanismus an der Universität Leipzig (Wiesbaden: 2008) 181-193.
} 
style as the Albrechtsburg. Stercker is attested as an eager recipient of the ideas of Enea Silvio Piccolomini, and it can be assumed that he was also familiar with Piccolomini's main ideas on the renewal of architecture in their general outline.

In this essay it cannot be discussed conclusively whether the Albrechtsburg and the smaller palaces at Rochlitz and Sachsenburg display further conceptual innovations beyond the conspicuous and innovative staging of historicizing vaulted chambers. A main feature which clearly reveals connections with favourite architectural topics of Italian humanists, among them Enea Silvio Piccolomini, was the elaborate staging of the vista into the surrounding landscape, which Enea in particular had praised many a time. ${ }^{116}$ Piccolomini constructed concurrent buildings with their loggie in Pienza in the 146os, and later, in Trent, so did his friend and early pupil Bishop Johannes Hinderbach from Rauschenberg, in Hessia (1418-1486). ${ }^{117}$

It seems likely that the examples of Saxon architectural staging of the landscape views did not happen independently of such southern aims and experiments. ${ }^{118}$ Even for Hinderbach the parallel reception of Romanesque architectural motifs can be proven. In particular, such is the case for the loggia with columns in the Romanesque style constructed ca. 1480 for the episcopal palace of Trent and surely inspired by suggestions by his Italian mentor.

In this context, one must understand the role of the humanist councillor Heinrich Stercker as an intellectual advisor for the introduction of new architectural ideas in collaboration with the architect Arnold of Westfalen at the electoral Saxon court from 1469. For the moment little more than a hypothesis, it gains in plausibility in particular through connections that have recently come to light between humanist interrelations and the conspicuous coeval as well as colocated reception and development of new architectural ideas in other courtly centres of the northern Alpine cultural region.

116 Tönnesmann A., Pienza. Städtebau und Humanismus (Munich: 1990); Esch A., "Das Erlebnis der Landschaft bei Enea Silvio Piccolomini/Pius II.", Das Mittelalter. Perspektiven mediävistischer Forschung 16, 1 (2011) 149-160; Esch A., Landschaften der Frührenaissance. Auf Ausflug mit Pius II. (Munich: 2008). Cf. Blum G., Fenestra prospectiva. Architektonisch inszenierte Ausblicke: Alberti, Palladio, Agucchi (Berlin - Boston: 2015); Ackerman J.S., The Villa. Form and Ideology of Country Houses (London: 1990) in particular 77.

117 Rando D., Johannes Hinderbach (1418-1486). Eine 'Selbst'-Biographie (Berlin: 2008).

118 Hoppe S., "Das renaissancezeitliche Schloss und sein Umland. Der architekturgebundene Fächerblick als epochenspezifische Herrschaftsgeste", in Holzner-Tobisch K. Kühtreiber T. - Blaschitz G. (eds.), Die Vielschichtigkeit der Strasse. Kontinuität und Wandel im Mittelalter und der frühen Neuzeit, Veröffentlichungen des Instituts für Realienkunde des Mittelalters und der Frühen Neuzeit 22 (Vienna: 2012) 303-329. 


\section{Humanist Translation Theory and the Beginnings of a Renaissance Architecture in Germany}

Every so often art history has addressed the issue of a possible intellectual background for the architectural development in Germany in the transitional area between medieval craftsmanship and beginning Renaissance culture. ${ }^{119}$ One of the first printed works of the modern theory of architecture in general - after the print of Alberti's De re aedificatoria in the previous year - was presented in 1486 in the sphere of the court of the above-mentioned humanist bishop of Eichstätt, Wilhelm of Reichenau. ${ }^{120}$ The author of the small booklet Büchleins der Fialen Gerechtigkeit was the Ratisbon master builder Matthäus Roritzer (1430/40-ca. 1492/1495), who belonged to the same generation as many of the people already presented here.

So far, modern scholars have not been able to agree about the exact interpretation of this process. While the later deliberations in architectural theory by Albrecht Dürer (1471-1528), who belonged to the next generation, have always been seen in the context of the developing art theory of the Renaissance, the interpretation of the early publications by Roritzer vacillates, since these works concentrate on geometrical foundations and single motifs of late-Gothic design. Some years ago, Hubertus Günther supported the interpretation as an early product of humanist interest in theoretical architectural issues, here mathematics and geometry and the dynamics of artistic design. ${ }^{121}$

The Ulm example of the choir stalls transcending the borders of art genres attests that the architectural innovation process was more complex than the traditional and somewhat romantic image of a fifteenth-century masons' yard culture north of the Alps. A wider circle of protagonists interested in art and architecture and with a new intellectual profile may be recognized, at least to some extent. These persons seem to have been predestined for the transfer and implementation of certain new ideas about art and its quality and origins.

119 Günther H.(ed.), Deutsche Architekturtheorie zwischen Gotikund Renaissance,(Darmstadt: $1988)$ 31; Kruft H.W., Geschichte der Architekturtheorie. Von der Antike bis zur Gegenwart (Munich: 2004) 41-42.

120 Geldner F., "Matthaeus Roritzers 'Büchlein von der Fialen Gerechtigkeit' und die beiden Ausgaben des 'Visierbüchleins' von 1485', Gutenberg-Jahrbuch 38 (1963) 6o-66; Strohmayer W., Das Lehrwerk des Matthäus Roriczer (Hürtgenwald: 2004); Schmitt L., "Über die schwere Geburt des deutschen Architekturtraktats. Die Wiegendrucke Mathes Roriczers und Hanns Schmuttermayers", Scholion 3 (2004) 168-174; on the architecture by Roritzer cf. Huber M.T., Die Westfassade des Regensburger Doms. Konvention und Innovation in einem spätmittelalterlichen Hüttenbetrieb (Regensburg: 2014) 310-337. Huber also attributes the Eichstätt branch work vault from 1471 to Roritzer (p. 327).

Klinnert R., "Matthäus Roritzer", in Günther, Deutsche Architekturtheorie 31-36. 
At the time, humanist circles were deeply fascinated by the discovery and deeper understanding of further ancient texts on the art of rhetoric. The more technical texts, such as Cicero's De inventione and the pseudo-Ciceronian Rhetorica ad Herennium, had been widely used in the Middle Ages, in school and university education, as well as for practical applications, such as letter writing. ${ }^{122}$ But the complete texts of more sophisticated works in terms of content, however, i.e. Cicero's De oratore and Quintilian's Institutio oratoria, were only rediscovered and put into service during the fourteenth and early fifteenth century, and thus became now available for new art-theoretical approaches. ${ }^{123}$ As a result, the field of ancient rhetoric, keenly received by humanists with its manifold implications for everyday life and the arts in particular, gained an interesstig sub-theme for our investigation.

From the 1450s, the practice and theory of the art of literary translation met with a very positive response in early southern German humanism. ${ }^{124}$ Joining deliberations on translating known since the Middle Ages, such as Cicero's De optimo genere oratorum ( $46 \mathrm{BC}$ ), was Quintilian's complete treatise on rhetoric, which had been fully rediscovered in 1416/1417 by the humanists. Around 1420/1426 Leonardo Bruni created in Italy a treatise entitled De interpretatione recta, which constituted the first humanist work on this issue. ${ }^{125}$

Gregor Heimburg from Franconia (ca. 1400-1472), ${ }^{126}$ otherwise better known for his political reform plans and his political career, already constitutes an early German example for the reception of humanist ideas from Italy. ${ }^{127}$

122 Leidl C.G., "Cicero. B. De inventione und Rhetorica ad Herennium", in Walde C. (ed.), Die Rezeption der antiken Literatur. Kulturhistorisches Werklexikon, Der Neue Pauly, suppl., vol. vII (Stuttgart - Weimar: 2010) cols. 214-229.

123 Vickers B., In Defence of Rhetoric (Oxford:1988);Vickers B., "Humanismus und Kunsttheorie in der Renaissance", in Forster K.W. - Locher H. (eds.), Theorie der Praxis. Leon Battista Alberti als Humanist und Theoretiker der bildenden Künste (Berlin: 1999) 9-74; Brassat W. (ed.), Handbuch Rhetorik der Bildenden Künste (Berlin - Boston: 2017) with numerous articles on this theme.

124 Vermeer H.J., Das Übersetzen in Renaissance und Humanismus (15. und 16. Jahrhundert), vol. 2: Der deutschsprachige Raum (Heidelberg: 200o); Schwarz W., "Translation into German in the Fifteenth Century", The Modern Language Review 39 (1944) 368-373.

125 Norton G.P., "Humanist Foundations of Translation Theory (1400-1450): A Study in the Dynamics of Word", Canadian Review of Comparative Literature. Revue Canadienne de Litterature Comparee 8, 2 (1981) 173-203; Botley P., Latin Translation in the Renaissance: The Theory and Practice of Leonardo Bruni, Giannozzo Manetti, Erasmus (Cambridge: 2004).

126 Hiksch J., Gregor Heimburg (um 1400 bis 1472), Politiker zwischen Mittelalter und Neuzeit, Ph.D. dissertation (Potsdam University: 1978).

127 Among the more substantial modern surveys on the German history of literature of this time: Rupprich H. - Heger H. (eds.), Geschichte der deutschen Literatur, vol. IV, 1: 
He may be considered as having formulated at least implicit deliberations on the challenges of translating. However, three other German humanists of the first generation emerged much more prominently in this field. All of them lived and worked in the the vicinity of Ulm, or even for many years in the city itself: the city scribe Niklas of Wyle (ca. 1410-1479), who worked until 1469 in Esslingen and later in the service of the counts of Württemberg; the Ulm city physician Dr Heinrich Steinhöwel (1410-1479); and the Franconian canon Albrecht of Eyb (1420-1475) ${ }^{128}$ in neighbouring Eichstätt.

The theme of translating as a means of transmitting culture was not new, since in the Middle Ages there was already an existing awareness of the fact that the Holy Scriptures existed mainly in the form of textual translations. The point of reference for the translation of a secular text was usually Cicero, who had explained principles of translating in De optimo genere oratorum (IV, 13, to V, 14). ${ }^{129}$ Horace later sided with him substantially in his Ars Poetica (II, 128-144). ${ }^{130}$ Technical terms used were ad sensum for the analogous translation and ad verbum for the verbatim translation. In antiquity, one actually agreed with Cicero and Horace that a translation really ought to be done analogously. Clinging too tightly to the grammatical structures of the source language was seen as rather negative.

With this straightforward referential context, one possible testament to the lively dynamic and intellectual importance of the topic during the second half of the fifteenth century north of the Alps is if, among the three mentioned and interconnected German translators, both possible modes of translating were raised and considered.

Das ausgehende Mittelalter, Humanismus und Renaissance 1370-1520, 2nd ed. (Munich: 1994); Cramer T., Geschichte der deutschen Literatur im späten Mittelalter, 3rd updated ed. (Munich: 2000); recommended in particular: Burger H.O., Renaissance, Humanismus, Reformation. Deutsche Literatur im europäischen Kontext (Bad Homburg v.d.H.: 1969). Most surveys are still based on many problematic notions regarding this era that have long since revised by specialized research.

128 Limbeck S., Theorie und Praxis des Übersetzens im deutschen Humanismus. Albrecht von Eyb's Übersetzung der 'Philogenia' des Ugolino Pisani, Ph.D. dissertation (AlbrechtLudwigs-Universität zu Freiburg i. Br.: 2000); Rautenberg U., "Albrecht von Eyb und die Ehe-Diskussion in der Übersetzungsliteratur deutscher Humanisten", in eadem (ed.), Über die Ehe. Von der Sachehe zur Liebesheirat, exh. cat., Bibliothek Otto Schäfer (Schweinfurt: 1993) 46-50.

129 Weissbort D., "From Cicero to Caxton: Classical Latin and Early Christian Latin Translation", in idem - Eysteinsson Á. (eds.), Translation: Theory and Practice: A Historical Reader (New York: 2006) 21 (with English translation).

130 Weissbort, Translation 22 (with translation by Ben Jonson ca. 1640). 
On the one hand, the analogous mode might refer to ancient authorities, such as Cicero and Horace, as well as to the mainstream of current practice. On the other hand, the stricter ideal of a verbatim translation noticeably interfered with the grammar of the (German) target language.

Sven Limbeck stated in a current study on the theory and practice of translating by Albrecht of Eyb:

In der frühen Neuzeit entfaltet sich im deutschen Sprachgebiet, insbesondere unter dem Einfluss des italienischen Humanismus, ein Problembewusstsein um die adäquate volkssprachige Wiedergabe fremdsprachiger, d. h. in dieser Zeit vornehmlich lateinischer, Texte. Die Übersetzer diskutieren diese Probleme nach einem aus der Antike übernommenen Muster, bei dem sich wörtliches und sinngemäßes Übersetzen oppositionell gegenüberstehen. Obwohl nach den Maßgaben der antiken Übersetzungstheoretiker Cicero, Horaz und Hieronymus der "ad sensum"Übersetzung der Vorzug zu geben ist, bildet sich in der frühen Neuzeit eine Übersetzungsrichtung heraus, die die wörtliche Anlehnung an die lateinischen Ausgangstexte präferiert. Sie hat besonders im schwäbischen Frühhumanismus um den Grafen Eberhard im Bart ein gesellschaftliches Zentrum. Gleichzeitig und in der Folge überwiegt jedoch die Zahl der Übersetzer, die ihre sinngemäße Übersetzungspraxis unter Berufung auf Horaz und Hieronymus rechtfertigen und gerade dabei ein hohes Maß an Bewusstsein um die Verpflichtung zur Originaltreue entwickeln. ${ }^{131}$

We remember the Württemberg Count Eberhard the Bearded in the sphere of the Bebenhausen monastery as one of the first princely patrons of humanism in Germany. In the 1470s, he ruled in the small and then largely embellished town of Urach, ca. $55 \mathrm{~km}$ from Ulm. Count Eberhard was in close contact with the Esslingen city scribe Niklas of Wyle, who had practised the ad verbum type of translation into German from the early 1460 s and had them printed in 1478 as a selection of collected 'Translazen'.

In addition, Wyle also defended the ad verbum strategy by giving it a theoretical underpinning. ${ }^{132}$ The introduction to the printed anthology states:

131 Limbeck, Albrecht von Eyb's Übersetzung der 'Philogenia' des Ugolino Pisani 128.

132 Greule A., "Der frühhumanistische Kanzlist Niklas von Wyle und die frühneuhochdeutsche Sprachkultur", in Hünecke R. - Aehnelt S. (eds.), Kanzlei und Sprachkultur (Vienna: 2016) 11-21; Schwenk R., Vorarbeiten zu einer Biographie des Niklas von Wyle und zu einer kritischen Ausgabe seiner ersten Translatze (Göppingen: 1978); Tisch J.H., "The Rise of the Novella in German Early Humanism: The Translator Niclas von Wyle (c. 1410-1478)", in Treweek A.P. - Australasian Universities Language and Literature Association (eds.), Proceedings and Papers of the Twelfth Congress Held at the University of Western Australia, 
'deshalb aber not gewesen ist; mich in disen translatzen by dem latin (so nechst ich mocht) beliben sin, vmb daz nützit der latinischen subtilitet durch grobe tütschung wurd gelöschett' ('but therefore it was needful that I keep myself in these translations as closely to the Latin as I was able to do, so that none of the Latin subtlety would be lost through crude deceit'). ${ }^{133}$

Applied to the German vernacular as a target language, Wyle's strategy often led to unusual formulations and new grammatical structures. Nonetheless, Wyle's innovative work exercised a lasting influence on the formal development of the German language of the period (Frühneuhochdeutsch). ${ }^{134}$

One of the prominent representatives of the other model - i.e. a freer translation practice ad sensum, which allowed the local vernacular tradition greater influence on the final product - was Albrecht of Eyb in Eichstätt. ${ }^{135}$ In Albrecht's case, his free approach to translation work into the German vernacular manifested itself in his Ehebüchlein (Marriage Booklet) printed in Nuremberg in 1472, as well as in the Spiegel der Sitten (Mirror of Customs), completed in 1474 but published posthumously. ${ }^{136}$

The second prominent representative of the freer translation practice was Heinrich Steinhöwel, already mentioned above as a possible provider of ideas for the innovative architecture in Ulm. ${ }^{137}$ Steinhöwel practised the principle of the analogous translation in his German or bilingual editions of Boccaccio's De mulieribus claris and of the Fables of Aesopus, which ca. 1474 were printed in Ulm as the book Von den Synnrychen Erluchten Wyben and 1476 as Buch und Leben des Hochberühmten Fabeldichters Aesopi. In the preface to the Speculum Vitae Humanae Steinhöwel explained his method of translation:

Darynne ich dem Spruch Oracij nachvolget hab. Lutend du getruwer dolmetsch nit wellest allweg eyn wort gegen wort transferieren. sonder geburt sich und ist gnuog ausz eynem synne eynem andern synne. doch geleicher mainung zesetzen. das ich dann in diser meyner translacion auch an etlichen orten getan und ettwann etliche wort hab gelassen czuo

5th-11th February 1969 (Sydney: 1970) 477-499; Vermeer, Das Übersetzen in Renaissance und Humanismus $5^{26-549 .}$

133 Keller A. von (ed.), Translationen von Niclas von Wyle (Stuttgart: 1861, reprint 1967) 10.

134 Polenz P. von, Deutsche Sprachgeschichte vom Spätmittelalter bis zur Gegenwart (Berlin New York: 1999).

135 Limbeck, Albrecht von Eyb's Übersetzung der 'Philogenia' des Ugolino Pisani, passim.

136 On the Ehebüchlein, 1471, completed as manuscript, see the Marburger Repertorium zur Übersetzungsliteratur im deutschen Frühhumanismus (MRFH) 40201, URL: http://mrfh .de/40201; on the Spiegel der Sitten MRFH 40202, URL: http://mrfh.de/40202, pages accessed 9 July 2017; Kümper H. (ed.), Das Ehebüchlein. Nach dem Inkunabeldruck der Off. Anton Koberger, Nürnberg 1472 (Stuttgart: 2008).

137 Vermeer, Das Übersetzen in Renaissance und Humanismus 549-568. 
loffen oder abgebrochen czuo merer verstaentnusz den lesenden menschen disz buoches.

Therein I followed the maxim of Horace: You should not, faithful interpreter, translate by always using a precise equivalent for each single word, it is right and sufficient to use a word with a different sense while at the same time maintaining the overall meaning. I have done so in this my translation in several places, and have then left out several words or broken them off for the better understanding of the humans who read this book. ${ }^{138}$

Compared to these early literary translation projects into the German language - born of a spirit of humanism and at the time concentrated particularly in Swabia and in southern Franconia - the artistic experiments with reform and enrichment of the traditional northern Alpine formal language of architecture also seem to show two different ways of dealing with antique sources. One imagines the manifold architectural projects referred to above acting as models for the creation of a new architectural language that refers to distant origins in antiquity and to a distant culture. And one seems to recognize two positions of artistic production that seem analogous to the two positions discussed in the contemporaneous humanist translation practice.

In building projects - such as the Burghausen or the Salzburg palaces, the Dresden dining hall, the Moosburg gallery, the Ulm town house column from 1482 [Fig. 19.20], or the case of the inclusion of Romanesque spolia in the stylistically contrasting ecclesiastical buildings of Freiberg, Salzburg, Millstadt, or Bebenhausen - the original grammar of the Romanesque style remained recognizable as being almost unchanged. The artistic strategy seems analogous to the verbatim school of translation of a Niklas of Wyle and of its formal faithfulness in translating adverbum. As in the case of Wyle, this method brought with it a certain aesthetic rigour and alien style as the outcome. The results could be assimilated only to an extent into further northern Alpine architectural development and have not yet been included at all by modern art history into the narrative of the early Renaissance building culture of the North.

Alternative strategies for dealing with the stylistic idiosyncrasies of Romanesque and ancient architecture, like in Meißen or Rochlitz, tried to connect the ancient principles of the Romanesque language, as the reduction to the vaulting bowl and its volumina, with the modern late-Gothic artistic

138 Fol. $7 \mathrm{~b}$ of the autograph, cgm. 1137. Cited in accordance with Harthun K., Die Übersetzungspraxis des deutschen Frühhumanismus, Kindle Version: Position 809. 

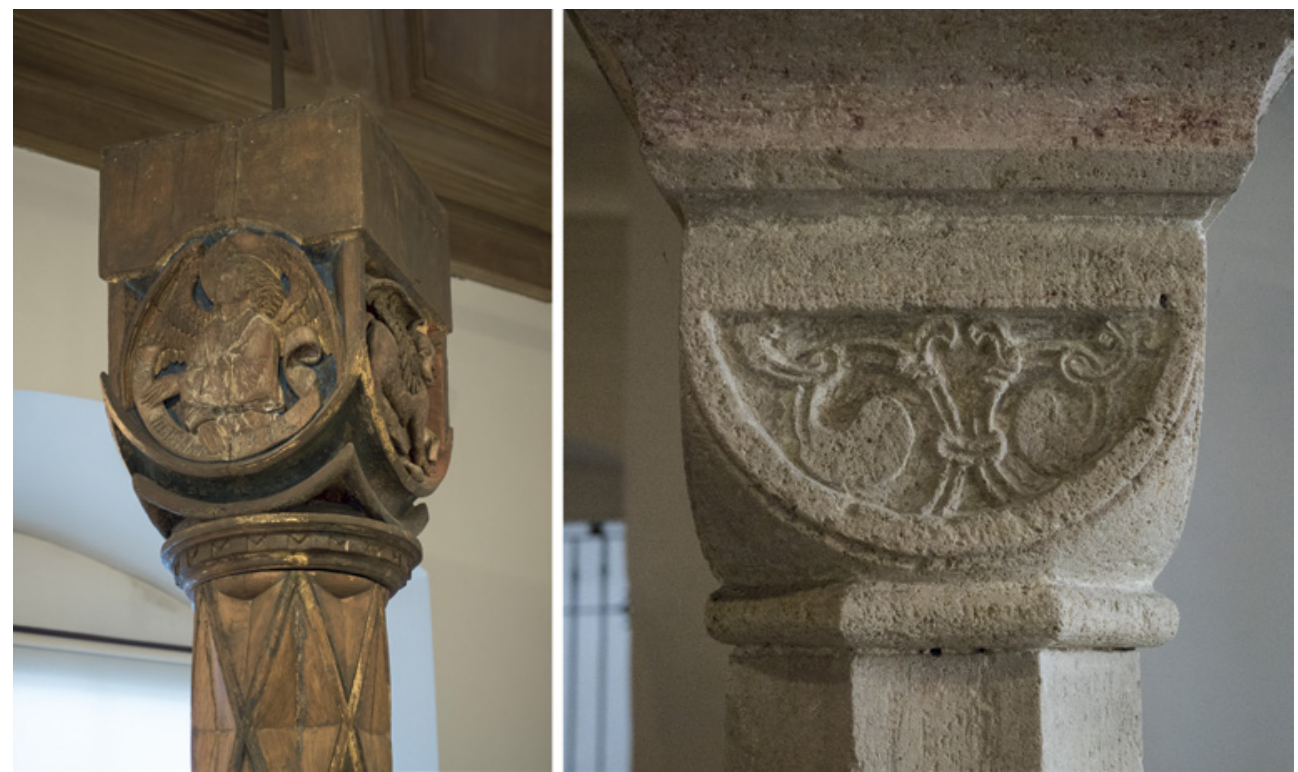

FIGURE 19.20 Left: Romanesque Renaissance column from an Ulm townhouse (1482). Museum Ulm. Right: Romanesque column, Regensburg St Emmeram West Crypt (ca. 1050)

IMAGE (C) AUTHOR

achievements, such as vaults with sophisticated figured ground plans. The new solutions of this free and highly innovative fusion of two stylistic worlds would become popular in Central Europe and continue to inspire even younger generations of master builders.

In this initially much more successful strategy of the 'analogous' design, compared to the 'verbatim' adoption of Romanesque building motifs, one almost expects to find aims similar to the translating principles of the translation ad sensum as promoted by Heinrich Steinhöwel as a kind of art-theoretical basis.

At the moment, the meaning and status of such structural similarities in literature and visual arts are still difficult to gauge. Nevertheless, one should recall here some more 'translated' motives of contemporaneous building culture. For example, ca. 1470 on the exterior building of the Ulm Minster a language of wooden constructions was 'translated' into figures of modern Gothic tracery [Fig. 19.21].139 The iconography of this new architectural language seems to depend on Tacitus descriptions of ancient German wooden buildings and

139 Huber, Die Westfassade des Regensburger Doms 328 dates the Ulm astwerk motives around the year 1465 . 


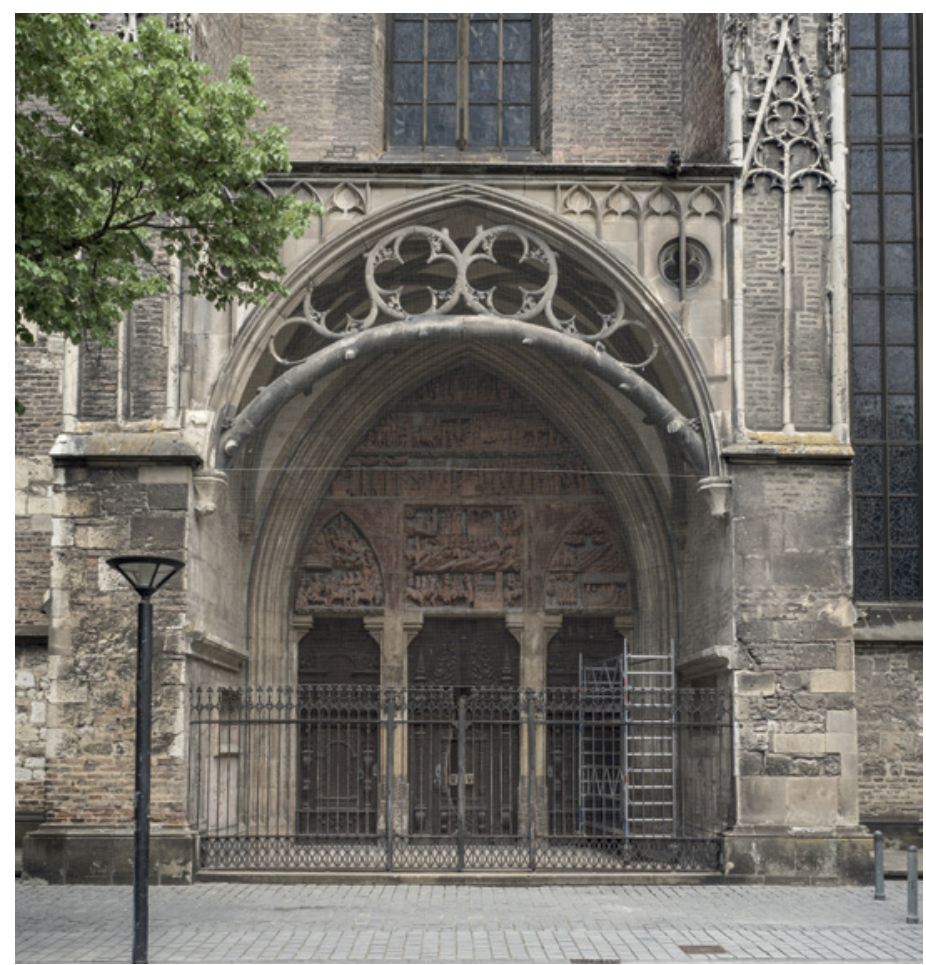

FIGURE 19.21 Moritz Ensinger, north-east portal of Ulm Minster, with branch work of ca. $147^{\circ}$ IMAGE (C) AUTHOR

new pictures of the era like in the Augsburg chronicle while the grammar was mostly modern Gothic. ${ }^{140}$ In these very early architectural experiments with

140 Cf. Crossley P, "The Return to the Forest, Natural Architecture and the German Past in the Age of Dürer", in Gaehtgens TW (ed.), Künstlerischer Austausch. Artistic Exchange, Akten des XXVIII. Internationalen Kongresses für Kunstgeschichte Berlin. 15--20. Juli 1992, vol. II (Berlin: 1993) 71-80; Krohm H, "Der 'Modellcharakter' der Kupferstiche mit dem Bischofsstab und Weihrauchfaß", in Châtelet A. (ed.), Le beau Martin. Etudes et mises au point (Colmar: 1994) 185-207; Günther H., "Das Astwerk und die Theorie der Renaissance von der Entstehung der Architektur", in Heck M.C. - Lemerle F. - Pauwels Y. (eds.), Théorie des arts et création artistique dans l'Europe du Nord du XVIe au début du XVIII siècle (Villeneuve d'Ascq: 2002) 13-32; Hubach H., "Johann von Dalberg und das naturalistische Astwerk in der zeitgenössischen Skulptur in Worms, Heidelberg und Ladenburg", in Bönnen G. - Keilmann B. (eds.), Der Wormser Bischof Johann von Dalberg (1482-1503) und seine Zeit (Mainz: 2005) 207-232; Hubach H., "Zwischen Astwerk und Feston. Bemerkenswertes zum Epitaph des kurpfälzischen Hofgerichtssekretärs Paul Baumann von Oedheim (1488)", in Hubach H. - Orelli-Messerli B. von - Tassini T. (eds.), 
the so-called branchwork (Astwerk), the idea of an 'analogous' (ad sensum) transformation of imagined ancient building modes into the tracery grammar of modern Gothic seems to be an illuminating concept and matches very well with the humanist background of a lot of such branchwork architecture. In the case of the branchwork, too, an application of the appropriate 'loose' and integrating artistic transfer strategy would have meant an impressive success story, as is attested by the numerous adoptions from the 148 os onwards in Germany and elsewhere. From this perspective, the transformation of the originally purely geometrical building element of the Gothic vaulting rib into a vegetable branchwork in Eichstätt Cathedral in 1471 may well be understood in some likelihood as a direct and early application of a kind of newly developped artistic strategiy in an ad sensum mode.

Perhaps even in the field of the architectural stylistic transformation and fusion during the fifteenth century the principle of audience orientation was valid, something which the German philologist Sven Limbeck formulated as follows:

But the type of translation contemporary early modern translators preferred depended to a large degree on the type of audience that is supposed to be reached by the translated text. Those who from the start targeted exclusively societal and educational elites may well have disregarded the requirements of those of an average education. To be intelligible to a German readership who does not know Latin, translators needed to adjust themselves to the level of education and to the cultural, societal, religious, and linguistic customs of the intended audience. ${ }^{141}$

Against this background, it seems almost logical that the branchwork, which might had come out of a free ad sensum artistic transformation and transfer process, would subsequently disseminate itself in a hundred ways outside the educated humanist circles. The direct integration of Romanesque artefacts and stylistic principles, which was rather more to be regarded as an application of a verbatim (ad verbum) mode of artistic transfer of ancient sources, remained at first a matter of the elitist and educated as well as internationally up-to-date, leaders.

Reibungspunkte. Ordnung und Umbruch in Architektur und Kunst. Festschrift für Hubertus Günther, Studien zur internationalen Architektur - und Kunstgeschichte 64 (Petersberg: 2008) $115^{-122 .}$

141 Limbeck, Albrecht von Eyb's Übersetzung der 'Philogenia' des Ugolino Pisani 128-129. Translation by Andrea Gáldy. 
Deliberations of this kind perhaps hint at the fact that the buildings presented here corresponded far more to the intellectual principles of humanism and the Renaissance than, for example, the slightly younger Fugger Chapel in Augsburg, even though the latter is every so often mentioned as point of departure for Renaissance architecture in Germany. The Augsburg chapel merely constitutes an adoption of some Venetian architectural models and the connection to what has been at this point long adopted as normal, star or lierne rib vault. Buildings such as the Albrechtsburg or the vaulted hall at Burghausen display a new attention to historical change (Flavio Biondo's mutatio rerum regionumque $)^{142}$ and a new mode of adopting historical material into service, which is very typical of early humanism and the early Renaissance in Europe. The perception prevails that the new interests of the humanist movement and Renaissance-type innovative attempts led to highly diverse formal results, particularly during the early period of the era.

\section{Conclusions}

In general, the architectural phenomena described here and put under the term 'Romanesque Renaissance' allow for two types of interpretation that build on one another.

First of all, during the course of the fifteenth century, a growing artistic and intellectual interest in the material transmission of the precise form and the stylistic idiosyncrasies of Romanesque architecture may be established. The single objects of interest and their respective historical contexts - and not just in Germany - still need to be explored more carefully. In German scholarship a long-adopted trend to hypostatize 'die Gotik' as an ideal actor in stylistic development of this time may be observed. Such hypostatization already aggravates linguistically the integration of the phenomena described here into the international debate on the European Renaissance era. However, there ought to be no doubt that this process happened within the framework of the epochal intellectual and cultural change of the Renaissance, might it be considered as revolution or evolution. Single networks or entaglements within the phenomena of early humanist debate as well as the possible relationship to appropriate

\footnotetext{
142 Muhlack U., Geschichtswissenschaft im Humanismus und in der Aufklärung. Die Vorgeschichte des Historismus (Munich: 1991) 199-202; Müller G.M., Die 'Germania generalis' des Conrad Celtis. Studien mit Edition, Übersetzung und Kommentar (Tübingen: 2001).
} 
trends in Italy can already be proven. The supraregional embeddedness into the European context ought to be emphasized more forcefully in future.

The second interpretation that goes beyond this result concerns the contemporaneous understanding of the historiography connected to it. The new kind of interest in the material and formal traditions of a long-ago Romanesque architecture could, at the time, be activated in two ways. Both of them are equally typical of the European Renaissance.

At first the new interest means an innovative activation of the historical as well as identity-giving dimension of older cultural eras regarded as exemplary. The Romanesque period could be understood stylistically as a late phase of the tradition of ancient culture in general. This may have been the case with Jan van Eyck and during the early phase of discovering the stylistic diversities in Romanesque art. The phenomenon inserts itself into the 'Entdeckung der Stile' (discovery of styles), which Ulrich Pfisterer described for the early fifteenth century in Italy and interpreted within the framework of intellectual history. ${ }^{143}$ Flavio Biondo's mutatio rerum regionumque is a contemporaneous key concept.

The old buildings that north of the Alps were obviously increasingly regarded as testimonials of past epochs and as art objects worthy of imitation, could also be seen by learned Germans as testimonials for an increasingly appreciated own proto-history, similar to Italian debates at the time. Naturally, the relationship was with a differently peopled national and local history in the North. Augsburg is an early German example of the rewriting of its own history and of the connection of this history with a parallel notion of a different material culture. Such discussions were conducted in Germany at least since the last third of the fifteenth century more intensively and on diverse levels. ${ }^{144}$

Given the general lack of textual sources explaining the buildings from the northern Alpine region, today we cannot always precisely distinguish between the two kinds of contextualization. Surely, even in Germany there was competition between diverse images of the country's own history, as historical scholarship has been able to establish during recent years with the aid of German chronicles of the fifteenth century and of other humanist-influenced publications. ${ }^{145}$

\footnotetext{
143 Pfisterer, Donatello.

144 Hirschi C., The Origins of Nationalism: An Alternative History from Ancient Rome to Early Modern Germany (Cambridge - New York - Melbourne: 2012).

145 Brendle - Mertens - Schindling - Ziegler, Deutsche Landesgeschichtsschreibung; Patze H. (ed.), Geschichtsschreibung und Geschichtsbewusstsein im späten Mittelalter (Sigmaringen: 1987).
} 
In principle, the awareness of a new interest in the formal and aesthetic achievements of a previous period also allows for the interpretation of a prospective activation of such models. On this level, we would indeed have to look at an integrating development for a reform of the current northern Alpine architecture, just as the literary translation projects of a Wyle or a Steinhöwel were meant to be inspiration and models for one's own cultural and artistic progress. Here, the aim would have been less the staging of a stylistic difference to maintain a distance from the modern Gothic, than it would the reform and development of the arts. Such a scope was equally to be observed in Italy and included Italy's own modern achievements. In this plethora of scopes, the appropriate artistic strategy would not have consisted in the mere imitation of older and diverse styles, but the selection and transfer of artistic achievements from the past into modern art practice.

The examples show that the precise dating and more detailed (micro-) historical contextualization of the works are essential, while traditional and general art historical (period) style labels can sometimes be problematic. The examples assembled here fit with difficulty into a model of autonomous stylistic development. A history of stylistic options, which art history often termed as modi, seems more appropriate. ${ }^{146}$ The epochal context is the history of the emerging European Renaissance and the intellectual history of an early period of European humanism. It is understood as a part of an innovative intellectual and educational movement and entangled personal network of persons and works with a reference to ancient culture. Precisely for the European Renaissance, stylistic options were typical. And within humanism the phenomena of translation and cultural transfer were newly discussed with a reference to their aesthetic stylistic consequences.

146 Bialostocki J., "Zum Modusproblem in den bildenden Künsten" (first published 1961) in idem, Stil und Ikonographie. Studien zur Kunstwissenschaft (Cologne: 1981) 12-42. On contemporary conceptions of 'modern' and 'classical' architecture, see for a basic introduction: De Jonge K., "Style and Manner in Early Modern Netherlandish Architecture (1450-16oo): Contemporary Sources and Historiographical Tradition", in Hoppe - Nußbaum - Müller, Stil als Bedeutung in der nordalpinen Renaissance 264-285. See also Hipp H., Studien zur 'Nachgotik' des 16. und 17. Jahrhunderts in Deutschland, Böhmen, Österreich und der Schweiz (Tübingen: 1979); Hipp H., 'Die Bückeburger 'structura', Aspekte der Nachgotik im Zusammenhang mit der deutschen Renaissance", in Großmann G.U. (ed.), Renaissance in Nord-Mitteleuropa, vol. I (Munich - Berlin: 1990) 159-170. 


\section{Bibliography}

Bärnighausen H. (ed.), Schlossbau der Spätgotik in Mitteldeutschland, conference volume (Dresden: 2007).

Belozerskaya M., Rethinking the Renaissance: Burgundian Arts across Europe (Cambridge: 2002).

Blum G., Fenestra prospectiva. Architektonisch inszenierte Ausblicke: Alberti, Palladio, Agucchi (Berlin - Boston: 2015).

Brassat W. (ed.), Handbuch Rhetorik der Bildenden Künste (Berlin - Boston: 2017).

Burger H.O., Renaissance, Humanismus, Reformation. Deutsche Literatur im europäischen Kontext (Bad Homburg v.d.H.: 1969).

Chatenet M. - Kavaler E.M. (eds.), Le Gothique de la Renaissance, Actes des quatrième Rencontres d'architecture européenne, Paris, 12-16 juin 2007 (Paris: 2011).

Crossley P., "The Return to the Forest, Natural Architecture and the German Past in the Age of Dürer", in Gaehtgens T.W. (ed.), Künstlerischer Austausch. Artistic Exchange, Akten des XXviı. Internationalen Kongresses für Kunstgeschichte Berlin. 15.-20. Juli 1992, vol. II (Berlin: 1993) 71-80.

DaCosta Kaufmann T., Court, Cloister, and City: The Art and Culture of Central Europe, 1450-180o (Chicago: 1995).

Esch A., "Das Erlebnis der Landschaft bei Enea Silvio Piccolomini/Pius II.", Das Mittelalter. Perspektiven mediävistischer Forschung 16, 1 (2011) 149-160.

Esch A., Landschaften der Frührenaissance. Auf Ausflug mit Pius II. (Munich: 2008).

Franke B., "Ritter und Heroen der 'burgundischen Antike'. Franko-flämische Tapisserie des 15. Jahrhunderts", Städel-Jahrbuch N.F. 16 (1997) 113-146.

Greule A., "Der frühhumanistische Kanzlist Niklas von Wyle und die frühneuhochdeutsche Sprachkultur", in Hünecke R. - Aehnelt S. (eds.), Kanzlei und Sprachkultur (Vienna: 2016).

Günther H., "Das Astwerk und die Theorie der Renaissance von der Entstehung der Architektur", in Heck M.C. - Lemerle F. - Pauwels Y. (eds.), Théorie des arts et création artistique dans l'Europe du Nord du XVIe au début du XVIII siècle (Villeneuve d'Ascq: 2002) 13-32.

Günther H. (ed.), Deutsche Architekturtheorie zwischen Gotik und Renaissance (Darmstadt: 1988).

Günther H., "Die Vorstellungen vom griechischen Tempel und der Beginn der Renaissance in der venezianischen Architektur", in Naredi-Rainer P. von (ed.), Imitatio. Von der Produktivität künstlerischer Anspielungen und Mißverständnisse (Berlin: 2001) 104-143.

Helmrath J. - Muhlack U. - Walther G. (eds.), Diffusion des Humanismus. Studien zur nationalen Geschichtsschreibung europäischer Humanisten (Göttingen: 2002). 
Hirschi C., The Origins of Nationalism: An Alternative History from Ancient Rome to Early Modern Germany (Cambridge - New York - Melbourne: 2012).

HoppeS.,"DieAntikedesJanvanEyck.ArchitektonischeFiktionundEmpirieimUmkreis des burgundischen Hofs um 1435", in Boschung D. - Wittekind S. (eds.), Persistenz und Rezeption. Weiterverwendung Wiederverwendung und Neuinterpretation antiker Werke im Mittelalter (Wiesbaden: 2008) 351-394.

Hoppe S., Die funktionale und räumliche Struktur des frühen Schloßbaus in Mitteldeutschland. Untersucht an Beispielen landesherrlicher Bauten der Zeit zwischen 1470 und 1570 (Cologne: 1996).

Hoppe S. - Nußbaum N. - Müller M. (eds.), Stil als Bedeutung in der nordalpinen Renaissance. Wiederentdeckung einer methodischen Nachbarschaft (Regensburg: 2008).

Hubach H., "Johann von Dalberg und das naturalistische Astwerk in der zeitgenössischen Skulptur in Worms, Heidelberg und Ladenburg”, in Bönnen G. - Keilmann B. (eds.), Der Wormser Bischof Johann von Dalberg (1482-1503) und seine Zeit (Mainz: 2005) 207-232.

Kavaler E.M., Renaissance Gothic: Architecture and the Arts in Northern Europe 14701540 (New Haven: 2012).

Limbeck S., Theorie und Praxis des Übersetzens im deutschen Humanismus. Albrecht von Eyb's Übersetzung der 'Philogenia' des Ugolino Pisani, Marburger Repertorium zur Übersetzungsliteratur im deutschen Frühhumanismus 2 (Freiburg / Breisgau: 2000).

Müller G.M., Die 'Germania generalis’des Conrad Celtis. Studien mit Edition, Übersetzung und Kommentar (Tübingen: 2001).

Müller H., Habit und Habitus. Mönche und Humanisten im Dialog (Tübingen: 2006).

Nußbaum N. - Euskirchen C. - Hoppe S. (eds.), Wege zur Renaissance. Beobachtungen $z u$ den Anfängen neuzeitlicher Kunstauffassung im Rheinland und in den Nachbargebieten um 1500 (Cologne: 2003).

Ott M., Die Entdeckung des Altertums der Umgang mit der römischen Vergangenheit Süddeutschlands im 16. Jahrhundert (Kallmünz: 2002).

Patze H. (ed.), Geschichtsschreibung und Geschichtsbewusstsein im späten Mittelalter (Sigmaringen: 1987).

Pfisterer U., Donatello und die Entdeckung der Stile. 1430-1445 (Munich: 2002).

Saurma-Jeltsch L.E. - Frese T. (eds.), Zwischen Mimesis und Vision. Zur städtischen Ikonographie am Beispiel Augsburgs, Kunstgeschichte 87 (Berlin: 2010).

Seeliger-Zeiss A., Lorenz Lechler von Heidelberg und sein Umkreis. Studien zur Geschichte der spätgotischen Zierarchitektur und Skulptur in der Kurpfalz und in Schwaben (Heidelberg: 1967).

Smith J.C., The Northern Renaissance (London: 2004). 
Terrahe T., Heinrich Steinhöwels 'Appolonius', Marburger Repertorium zur Übersetzungsliteratur im deutschen Frühhumanismus 35 (Berlin: 2013).

Timmermann A., Real Presence: Sacrament Houses and the Body of Christ c. 1270-160o (Turnhout: 2009).

Vermeer H.J., Das Übersetzen in Renaissance und Humanismus (15. und 16.Jahrhundert), vol. 2: Der deutschsprachige Raum (Heidelberg: 2000).

Vickers B., "Humanismus und Kunsttheorie in der Renaissance" in Forster K.W. Locher H. (eds.), Theorie der Praxis. Leon Battista Albertials Humanist und Theoretiker der bildenden Künste (Berlin: 1999) 9-74.

Wood C.S., Forgery, Replica, Fiction: Temporalities of German Renaissance Art (Chicago: 2008). 